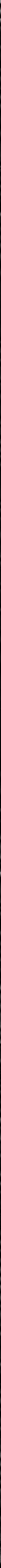






\section{THE STORY OF THE SHIRE}



Digitized by the Internet Archive in 2007 with funding from Microsoft Corporation 


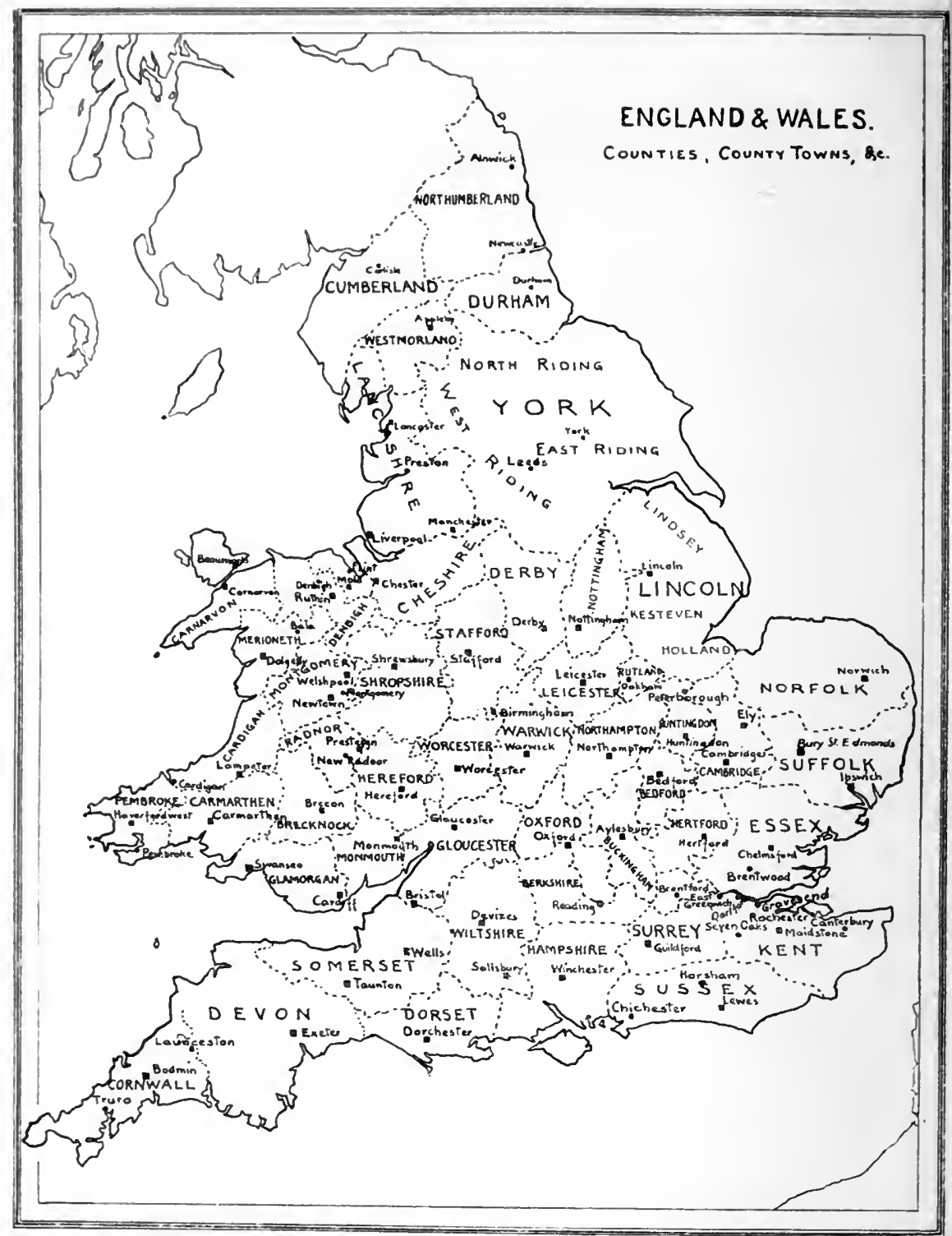

Frontispiece. 


\section{THE}

\section{STORY OF THE SHIRE}

BeING THE LORE, HISTORY AND Evolution

OF ENGLISH COUNTY InSTITUTIONS

BY

FREDERICK W. HACKWOOD

Author of "Inns, Ales, and Drinking Customs of Old England," "Old English Sports," \&c., dec.

"God gave all men all earth to love,

But since our hearts are small,

Ordained for each one spot should prove

Beloved above all."

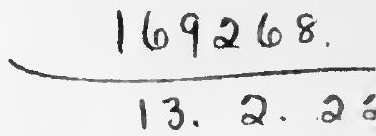

\section{HEATH CRANTON LIMITED}

6. FLEET LANE, LONDON, E.C. 4 


$$
\begin{aligned}
& 55 \\
& 3260 \\
& 133
\end{aligned}
$$




\section{LIST OF ILLUSTRATIONS}

I. MAP OF ENGIAND AND WALES-Counties, CountyTOWNS, ETc. $\quad . . \quad \ldots \quad \ldots \quad$... Frontispiece

Page.

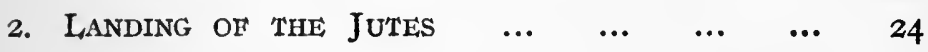

3. MaP OF ENGLAND-ANGLo-Saxon Kingdoms AND DANISH DISTRICTS $\quad \ldots \quad$...

4. A Case of Appeal, to the Witan $\quad \ldots \quad$...

5. LORd Mayor's Procession in Cheapside (I76I) $\quad$.. $\quad$ I20

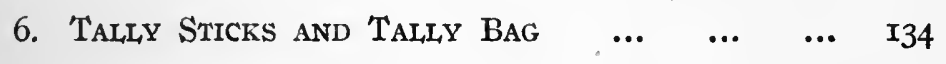

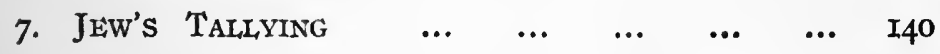

8. Sheriff's Carriage at County Hali $\ldots$...

9. MEETTNG OF THE SHIRE MOOT $\quad \ldots \quad$... 



\section{ANALYTICAL CONTENTS}

\section{I.-INTRODUCTORY.}

Shires, a Teutonic institution-the Anglo-Saxon Heptarchy.

The Jutes-found Kent (445)-given Thanet-and seize more territory.

The Saxons -found Sussex (477)-Wessex (495) - and Essex.

The Angles-found East Anglia-Deira-Bernicia -and Mercia (586).

Process of consolidation begins with Northumbria -Bamborough and Edinburgh-line of Northumbrian kings-succumbs to Wessex.

Diocese and kingdom co-terminous-Durham, a bishop's shire.

Strathclyde (or Cumbria)-a Celtic kingdom from the Mersey to the Clyde-no line yet drawn between England and Scotland.

Rise of Wessex-master of the south-midlands. All British influence gone-Britons driven westward-then Wales cut off from Cornwall (577)and from Cumbria (6I3)-Severn Valley left to Hwiccas (a mixed race).

The Bretwaldas-rise and decline of Mercia-the triumph of Wessex-a united England, 827-The name " England."

Varying fortunes of contending kingdoms-the language of the Angles prevails-Winchester, the first capital-the first shires.

The Welsh-made servile if not expatriatedEnglish shire system spreads into Scotland, Ireland, and Wales.

Englishman's mixed origin-love of self-government-autonomy of the local unit-the Anglian ideal-freedom rom a central control.

Individuality of the Shire-value of local experience-local independence the spirit of the English constitution-our common faith, "The Liberty of the Subject."

pp. $23-36$ 


\section{II.-BRITISH TRIBAL AREAS.}

Boundaries not constant-Distribution at Roman invasion-The Trinobantes (Essex and Middlesex)Iceni or Cenimagni (Norfolk and Suffolk) - Segontiaci (Hants and Berks)-Ancalites (Berks and Middlesex)-Bibroci (Hants, Berks, Sussex, Surrey, and part of Kent), Cassii (Herts, Beds, and Bucks) -and Cantii (Kent).

Two races-Goidels and Brythons (or Britons)Goidels occupy the three western peninsulas (Cumbria, Cambria, and Cornwall) - except for a wedge of the Ordovices in Mid-Wales-the Demetæ and Silures in S. Wales-the Damnonii in Cornwall -and Durotriges (Dorset and Somerset).

Coast-lands from Humber to Devon-and inland as far as Herts, Bucks, and Beds-occupied by a race distinct "rom the western portions-their civilisation higher-probably a people of Belgic Gaulwhile the Goidels of the west probably came from West France or the North of Spain.

North country held by Brigantes-flanked (Lancashire) by Segantii-and (Yorks) by Parisii-West Midlands occupied by Cornavii and East Midlands by Coritani-Thames Valley by Attrebates-and the sources by Dobuni-the Cantii held Kent, and the Regni Sussex-the Belgæ along the coast. Cantium, the most civilised part-the corn countries of the coast-the wild tribes of interior-the descriptions of Diodorus and Strabo-the Cornwall tin ores-conveyed to Vectis (?Wight)-no trace of the Phœnicians.

A second century survey-the Cantii (Kent)Regni (Surrey and Sussex)-Belgæ (Hants, Wilts, Somerset)-Durotriges (Dorset)-Iceni (Norfolk, Suffolk, Cambs, and Hants)-Coritani or Coritavi (Northants, Leicester, Rutland, Derby, Notts and Lincoln)-and Parisii (S. E. Yorks)-the Catuvillani (?Cassii) (Bucks, Beds, and Herts)Attrebates (Berks)-Dobuni (Oxon and Gloucester) -Brigantes (Northumbria)-Voluntii (W. Lancashire)-Sestuni (Westmoreland and Cumberland) -also Jugantes and Cangi. 
Another Catalogue-the Hedui (Somerset)-the Morini (Dorset) the Senones (Hants)-the Rhemi or Bibroci (Berks, Surrey and Sussex)-the Attrebates (Surrey and Hants)-the Cimbri (Devon) -and the Parisii (N.E. coast)-duplicate names attributable to foreign writers.

Belgic names that identify locality of origin-Attrebates from Artois-Cimbri from Cambrilla-Rhemi from Rheims-Senones from Sens-Parisii from Paris.

Wales-primitive tribes-Ordovices (Flint, Denbigh, Montgomery, Merioneth, Carnarvon and Anglesey) Demetæ (Cardigan, Carmarthen, Pembroke) - Silures (Hereford, Radnor, Brecon, Monmouth, and Glamorgan)-Cornavii (Warwick, Worcester, Stafford, Salop, and Chester).

Place-names betraying tribal locations-Cantii in Kent-Iceni at Ickborough-Bibroci at BrayCassii at Cashio-Damnonii in Devon-Durotriges in Dorset-Regni at Ringwood.

Tribal names and their meanings-some heroic tribesmen-Boadicia of the Iceni-Cymbeline of the Trinobantes - Cartismandua of the Brigantes Caractacus of the Silures - the names Coritavi, Catuvillani, Attrebates, Cornavii.

pp. $37-46$

\section{III.-BRITAIN DIVIDED INTO ROMAN PROVINCES.}

The first administrative divisions were Romangoverned as one province by emperor's Viceregent -aided by a Procurator.

Divided into two provinces, A.D. I97-then into four provinces-special officers appointed from Rome -the "Saxon Shore."

pp. $47-50$

\section{IV - ENGLAND DIVIDED INTO SHIRES.}

"Shires " credited to Alfred-not all in existence at the Conquest - first mentioned by Ina, 603-first ealdorman mentioned by name, 757 . 
Wessex comprised seven or eight shires-advanced its borders by settlements - or divided its territory among sub-reguli-the relationship between ealdorman and sub-regulus - shires named after royal vills. Mercia and Northumbria without an early shire system-ealdormen succeeding to sub-regulivassal kingdoms placed under duces - and possibly other units under ealdormen-Mercia comprised more than a dozen counties-Monmouth not an English county.

Hwiccia-its extent - a "Winchcombeshire "-the west-midland shires.

South Saxonia -East Anglia - first mention of Rutland -earl or ealdorman ? -or Danish " jarl ?" a system of grouping the shires.

Northumbria - ealdormen with a shire systemhereditary High-reeves-mixed Anglo-Celtic race - Cumbria, a Celtic province.

A Writ of Parliament in I275 mentions 37 counties -the three omitted-and why-the term "Province" has no obvious meaning in England.

pp. $5^{I-57}$

\section{V.-THE BORDER COUNTIES}

Undetermined appropriation of Northumbria and Strathclyde-both under influence of Edward the Elder-Cumbria conquered by Edmund, and let on military tenure to Scotland.

Northumbria divided into baronies and wardsNorthumberland an earldom-northern half, called Lothian, acquired by Scotland (IOI8)-Strathclyde also added to Scotland-the overlordship of England.

A united England and a united Scotland (I068)Malcolm III. does homage to William I. for Cumberland-Cumberland seized by Rufus-a "New Castle "-Edinburgh made the capital.

Durham a Norman earldom-devastation of the northern counties by the Conqueror-Northumberland scarcely English.

Northumberland, Durham and Westmoreland, recovered by Henry II-the hereditary High Sheriffs 
of Westmoreland-Scots king abandons claim to Northumberland and Cumberland.

A line of demarcation in 1237-but border warfare not ended.

North of the border line-the fortunes of BerwickLothian essentially English-shire system introduced into Scotland-old territorial divisions prevailed in Celtic parts-Galloway clans opposed to shire authorities-their tributary status.

pp. $58-63$

\section{VI.-SCOTCH SHIRES.}

While borders remain chaotic, the shire system finds its way into the northern kingdom-Gælicism recedes northward.

Scotland a confederation-Pictland-GallowayDalriada, or settlement of Irish Scots-the Norse settlement and the earldom of Caithness.

Three Gælic elements-the kingdom of Alban (844)-Highlands remain detached and semi-independent-the seven Gaelic Mormaers-the Norse element of Caithness, Orkneys, and Hebrides.

David I. introduces Shire System (II24)-Sheriffwicks, I305-expediency of making office hereditary -or for life-the number of sheriffs increased by Edward I.

Scottish parliament and the shire system-county representation-Orkneys and Shetlands, an insular county.

Cromwell's scheme of parliamentary representation -fixes a proportion between counties and burghs in Scotland-and groups the counties" commissioners" or members to sit in the House on "furmes" - method of Scotch representation -Scotch Sheriffs and their tenure. pp. 64-68

\section{VII.-WEISH AND IRISH SHIRES.}

From principalities to counties-from hereditary rulers to sheriffs.

Llewellyn's land formed into counties-Flint associated with Chester. 
South Wales re-organised on shire system-ancient laws of Wales retained but modified.

Henry VIII. divides Welsh Marches into shire lands-and legislates for uniformity with English system-disappearance of the Lord Marchers.

Shire divisions introduced into Ireland by Henry II.-the palatinates of Leinster, Meath, and Ulster - of Ormond and Desmond.

The "five obedient shires" of the Pale-shirelands extended in Mary's reign-the system completed under James $I$. pp. $69-73$

\section{VIII -COUNTY NOMENCLATURE.}

From a kingdom to a county-eight examplesnames related to points of the compass.

Counties named from clans-eight examples-legend of "Debon's share."

Counties named from the chief town-ancient burghal centres-Danish influence on place-nameswaterside towns-" "South-umberland "-towns at "ford" or " bridge:"-as Oxford-and Cambridge-Isle of Wight-" Hamptonshire" and Northamptonshire-Salop.

Names from physical features-woodland names -another legendary name.

Welsh county names-Celtic name legends.

General principles of the naming-county names that do not bear the terminal "shire"-county by-names and short names-exceptional spelling and pronounciation.

pp. 74-9I

\section{IX.-THE SHIRES AS EARLDOMS.}

The Ealdorman or Heretoga-the Shire-reeveold subject kingdoms as Earldoms-their semiindependence-brought into subjection by the Conqueror-the Ealdormen also sometimes troublesome.

Different status of Earl and Ealdorman-the real executive officer, the Sheriff-supersedes both Earl and Ealdorman. 
Ealdormen merged into Earls-only four Ealdormen at the Conquest-no titular Earls without counties.

A double nomenclature-Shire and County-Earl and Count-disappearance of the title " Count ""Earl " loses territorial significance-some countynames reserved for royal princes-others in the peerage.

pp. $92-97$

\section{X.-COUNTY ORGANISATION.}

Difficulties of a centralized government-met by divisions and subdivisions-influence of the church - "preost scyres" or parishes.

Division into Counties, Hundreds, and TithingsConstitution of the Hundred-northern and southern differ much in area.

Bookland and Folk-land.

Other divisions than Hundred and Tithing-as Lathe or Leth-of Roman origin-Wapentake due to Danish influences-and of military originRape, a Norman division.

Sokes-Ridings-natural boundaries.

Modern government subdivisions-North, East and West Ridings of Yorkshire-Holland, Kesteven, and Lindsey in Lincolnshire-East and West Sussex-East and West Suffolk-Isle of ElySoke of Peterborough-and Isle of Wight.

pp. 98-ro5

XI.-THE SHIRE COURT AND OTHER LOCAL COURTS.

Saxon basis of society the Family-influence of local custom-no uniform administration-Shire Moot held twice a year-anciently judicial and legislative.

Sheriff's Court-criminal jurisdiction-the processes of the Court-Ordeal-Compurgation-the Deman or "doomsman."

Delegated functions-Hundred Courts, once a month-Tithing or Township Courts-Tithing-man or Head-borough presided-intimate business of 
local moment dealt with-from township to feudal manor-manorial courts attacked by Edward I.rise of the Justices.

Hundred Courts--their constitution-influence of the clergy - the " wise men" or Witan-National Council or Parliament-the element of county representation- " Hustings" or voting assembly. From Folk Moot to Witan-grouped Shires-The Shire Court at its zenith-The first House of Commons an expansion of the Shire Court-Trial by J ury also traced to Shire Court procedure.

XII.-THE TOWNS.

pp. Io6-II4

Saxons not town-dwellers-the growth and grading of Towns-county aid to walled towns-" entire vills "-originally " one parish one tithing"corporate towns-market towns-cities-boroughs. London-a place apart of independent strength and prestige-the capital of the East Saxons-Winchester being capital of West Saxons-London given authority over Middlesex-long retained its Roman character.

London-a city of privileges-its first mayor-first Lord Mayor's Show-the complexity of modern local government.

pp. II5-I2I

\section{XIII._-"THE SHIRE MAN."}

Administrative areas-under deputed authority - the Ealdorman-and a royal officer.

The Shire Man, Scir-gerefa, or Shire-reeve-High Reeves-A constitutional officer-whose office has survived-The King's Bailiff of the Shire-annually appointed-by popular election.

In the north an heritable office-heritable jurisdictions abolished-County Keepers.

Popular choice confirmed by royal approvalelection superseded by Chancellor's nomination Originally the Scir-gerefa an executive officerafterwards a judicial officer-President of the Sheriff's Court-judicial powers waned after appointment of Justices in Eyre-and Justices of the Peace. 
Origin of Trial by Jury-local juries in Shire Courts. Custos Comitatus-the Sheriff's concern in other county matters-as revenue officer-as miliofficer.

Commander of the County forces-The Fyrd or national army-Posse Comitatus-how the levy was raised-its composition-its character changed by Feudai System-baronial retainers differed" livery and maintenance."

Decline of feudal levies-Sheriff superseded by Lord Lieutenant.

pp. $122-130$

\section{XIV.-THE COUNTY ESCHEATOR.}

From Witan to Great Council-Exchequer Courtcomposition of fixed revenue.

The Escheator-accounted for the Ferm of the Shire-" Sheriff-geld "-Danegeld.

Finance reform after Conquest-Sheriff as an accountant-business routine at the Exchequerthe Treasurer-the " chequed" or chessboard table-tallies.

The tally system-described-abolished I826satirised by Charles Dickens.

The Treasury at Westminster-the Exchequer in session-the Court of accounts-Sheriff presumed to be illiterate.

Shrievalties held by barons-thesaurarial and judicial functions of the Exchequer separatedimportance of Sheriff's Office-Statute of Sheriffsappointments to be made by Chancellor-become annual-scandals at the Exchequer (1389)-a change of sheriffs as a political barometer-appeals for money moved from Parliament to the County Courts.

pp. I3I-I 40

\section{XV.-THE KNIGHTS OF THE SHIRE}

A connection between Shire Courts and the High Court of Parliament-the function of the County in parliamentary representation- "Wise Men" of the Folk Moot continued after Heptarchy as Shire Moot-and a Superior Council set up. 
Domesday practice of sending Commissioners to consult Shire authorities-local representatives brought together by De Montfort-original objects purely financial-37 counties and many burghs summoned by writ-but always through the Sheriff.

Sheriffs not impeccable returning officers-false returns made.

A democratic franchise-a property qualification set up-comparative values of a "forty shilling freehold "- a restrictive franchise-the influence of large landowners.

As returning officer for boroughs and cities-discretionary power as to enfranchisement of " trading towns "-boroughs by prescription-Writs of summons always to the Sheriffs-who determined what towns should send members-some towns indifferent-and represented only by the Knights of the Shire.

Reform Act of I832-some counties divided into two-some given an additional member-some left unchanged with two members-Welsh counties retained one member each-Scotch counties with one member each and some with only alternate representation.

The Union of I80I-two members to each Irish county-an election song of I832-additional Sheriffs to large counties in I888. pp. I4I-I 49

\section{XVI.-THE HIGH SHERIFF.}

Sheriffs of London and Middlesex still electedHigh Sheriffs of counties nominated-the ceremony of the Law Courts-on " the morrow of St. Martin " - "pricking the Sheriffs" in February ensuing. Sheriffs, the link between Shire Moot and Curiathe Chancellor presides at ceremony- "Pocket Sheriffs "-objections to serve-excuses considered - the judges' recommendations-Rutland's exceptional treatment.

A costly office-examples of systematised extortion. 
Chief personal duty obligatory-attendance on the judges of Assize-chief ministerial officer of the Superior Courts-to the extreme penalty of the law-during year of office may not act magisterially. Decline in the importance of office-duties vicariously performed-the Under Sheriff-High Bailiff -of Hundreds-Constables and petty officersduties as Royal Bailiff-“'Sheriff's Posts."

pp. $150-159$

XVII.-THE ASSIZES AND THE COUNTY TOWNS.

Country divided into Circuits-visited by Judgesas the King's representatives-some ceremonial has therefore to be observed.

Two Assize Courts-the Crown Court-and Nisi Prius Court.

Originally six circuits-" justices in eyre "-other reforms effected through the Sheriffs-Assizes restrained to their own shires by Magna Charta.

The old circuits prior to I830-Welsh circuits added, I83I-circuit alterations in 1863.

Now there are eight circuits-the Northern-the North-Eastern-the Midland-the Oxford-the Western-the South-Eastern-the North Wales-and the South Wales-The position of London and Middlesex.

Four Assizes for all Circuits-but not for every Assize-town-certain groupings found inconvenient - smaller Assize-towns may be deprived of the privilege.

Old-time Assize-towns- " Maiden Assizes"judges sent as commissioners-" gaol deliveries."

pp. $160-168$

XVIII.-THE LORD LIEUTENANT OF THE COUNTY.

A military officer, tempo. Henry VIII.-also Custos Rotulorum- Sheriff superseded in military matters-but retains precedency.

An emergency officer-superseding Commissioners of Array-the earliest known appointment-with the duties set forth-instructions as to "armour and artillerie." 
From " Commissions of Array"-to Commissions of Lieutenancy" - the Militia-formerly officered by I,ord I,ieutenant-responsibility for Militia ballot.

Status of Lord Lieutenant-Deputy Lieutenants. pp. $169-$ I 76

XIX.-SHIRE BOUNDARIES.

Boundaries variously marked-meeting-places of three counties-" hoarstones."

Rectification of county boundaries-“ "foreign" areas-Ely Place Holborn, as part of Cambridgeshire-a list of out-lying territories-consolidated, I846-Kent and Essex once mixed up.

Pseudo-Shires - Norhamshire - Islandshire- Bedlingtonshire-Hexhamshire-BamboroughshireHallamshire-Richmondshire-Allertonshire.

pp. $177-\mathrm{I} 84$

\section{XX.-COUN'TIES CORPORATE AND COUUNTIES PALATINE.}

Every part of realm in some county-territories that are " counties corporate" by royal grant-in theory, though not in practice, on same footing as the other counties-legal constitution of a county corporate-a tendency to disregard this special status in parliamentary areas.

Nineteen old towns so distinguished-London, Bristol, York, Lincoln, Norwich, Newcastle, Hull, Nottingham, Southampton, Coventry, Canterbury, Haverfordwest, Gloucester, Chester, Exeter, Lichfield, Poole, Carmarthen and Worcester.

Berwick-on-Tweed-its peculiar status-geographical counties which include these privileged areas-Welsh and Irish examples.

Three counties palatine-Ely erroneously included -origin of privileged status - their superior courts. Legal definition of a palatinate-when institutedderivation of term "palatine"-the privilege of an independent and almost regal jurisdiction. 
The Palatinates of Chester-of Durham-and of Lancaster-Ely, formerly a royal franchise, is now vested in the Crown.

Two ancient palatinates, Pembrokeshire and Hexhamshire-all now deprived of ancient honours by enactments.

pp. $185-194$

\section{XXI - COUNTY SESSIONS, COUNTY COUNCILS AND COUNTY COURTS.}

Two inferior courts-Quarter Sessions with criminal jurisdictions-County Courts for civil businessa relic of the Shire Moot-decline of Sheriff's power -rise of the Justices-who were once elected-but now nominated by the Crown.

County committed largely to the Justices' careJustices' duties, Appellate and Original.

Sessions quarterly-the Chairman or Recorderprocedure-satirised-the Coroner.

Quarter Sessions a spending authority-but unrepresentative-reform called for-many proposals for re-constituted County Boards.

Elective County Councils substituted, I888-difficulties of financing Countryside government.

The County Borough-sixty-four large towns independent of the County government-London County Council.

A Standing Joint Committee-for control of Police. The County Court-quite modern-civil jurisdiction - simple and inexpensive.

The Stannary Courts of Duchy of Cornwall-The Cinque Ports.

pp. $195-205$

\section{XXII.-THE GEOGRAPHICAL COUNTIES.}

Four Northern Counties-poor land, rich coalfields-lakes and mountains.

Counties of the Humber Basin-great YorkshireNotts of old romance-Derbyshire, the English Switzerland,--Leicestershire on the Central PlainStaffordshire of the twin coalfields. 
Ribble and Mersey Basins-Lancashire, the richest coal-cellar in England-Cheshire, the salt-cellar of England.

West-midland Counties-Salop, merging into Wales -Worcester's rich valleys-Warwick, "the heart of England "-Gloster's grazing grounds-Hereford and the beautiful Wye-Monmouth, "the English Welsh" county.

East-midland Counties-fenny Lincolnshire-little Rutland-low-lying Huntingdon-Bedford and "the slow-winding Ouse"-Cambridgeshire and the Isle of Ely - “'The Bedford Level.'

East Anglia-Norfolk Broads-Suffolk pastures.

Thames Basin-Middlesex and Essex on lower reaches-pleasaut Hertfordshire-Bucks and the Vale of Aylesbury-Berks and the Vale of the White Horse-Surrey, Kent, and the North Downs.

Southern Counties-Weald of Sussex-Hampshire, "the county of Downs"-Wilts and Salisbury Plain-chalky Dorset.

South West Corner-diversified Somerset_Lovely Devonshire-Cornwall, the county which is a Duchy.

North Wales-Anglesey, the Island County-Carnarvon and Snowdonia-Denbigh in "Wild Wales "-Montgomery and Flint-and their mineral resources-Merioneth, and the Alsatia of Dinas Mawddwy.

South Wales-Cardigan and its sweeping bayPembroke, "Little England beyond Wales"sparsely populated Radnor and Brecon-busy Glamorganshire-Carmarthen, the largest Welsh County.

Aid to memorising the county names. pp. 206-2I9

\section{XXIII.-SHIRE “ PROVINCIALISM.”}

The Man from the Shires-the Home CountiesA Shire horse.

County separateness - north and south very distinct from each other-the northern harshness.

Line of demarcation-Mercia, the ethnological dividing line-dialect differences.

pp. $220-223$ 


\section{XXIV.-COUNTY ATTRIBUTES AND CHARACTERISTICS.}

The traditional Yorkshireman-his coat of armsLancashire law.

County nicknames--county comparisons in thyme -Cheshire cats-Lincolnshire bag-pipes-Wiltshire moonrakers-Derbyshire wise-Hertfordshire kindness-Stafford law.- the Bailiff of Bedford.

County pet names-The Home Shire-Woody Warwick-Breezy Berks-High Suffolk-Norfolcian Goose-greens-Beechy Bucks-Little Rutland - Nottingham dukeries - the Shire of Sea-kingsMiddlesex, rural London.

The Delectable Duchy-legend of I,yonesse-Somerset, most English of counties-Dorset the heart of Wessex.

Cheshire, the gateway of N. Wales-some characteristics of Welsh counties.

Staffordshire blue-Kentish fire-lore and legend of Kent-Men of Kent and Kentish Men-the tailed men of Kent-the real Dickens' county.

The pride of county productiveness - the various products for which certain counties have acquired wide reputation.

pp. $224-242$

\section{XXV.-COUNTY PATRIOTISM AND COUNTY RIVALRIES.}

County feasts-Devon and Cornwall clannishSussex pride in the Cinque Ports.

County rivalries-Worcestershire v. Gloucestershire-Cornwall v. Devon-Cheshire $v$. Staffordshire. Essex lions-the Cinderella county-its boasts - Silly Suffolk.

Self sufficiency in local custom-varying weights and measures-Troy Weight and Avoirdupois.

pp. $243-250$

\section{XXVI.-COUNTY BADGES.}

A county, having no corporate existence, was not entitled to bear arms-spurious arms generally of chief town or some distinguished earl-County Council inventions. 
Popular emblems of Kent-Lancashire-Yorkshire - Cornwall, etc.

County cognisances suggested by Mr. Alfred Rodway.

Michael Drayton's county heraldry-for Warwickshire - Worcestershire - Herefordshire - Staffordshire-Salop-Derbyshire-and their legends.

The battle streamers at Agincourt-distinguishing the county bands.

The Welsh battle standards. pp. $25 \mathrm{I}-262$

\section{XXVII.-THE COUNTY FAMILY.}

A power in the land-officially recognised in the organisation of the new Territorial army.

The county dignitaries-how county families are founded-old landed families and the new industrial plutocracy.

"County society" exclusiveness- " the county god."

Noble families. pp. $263-268$ 


\section{I}

\section{IN'TRODUC'TORY.}

The story of the English Shires begins with the Anglo-Saxon invasion; for the County, as we know it, is a peculiarly Teutonic institution. The Saxon Heptarchy is only a phrase; as a matter of historic fact the Norse invaders established more than seven kingdoms here.

The first was Kent, founded in 445 by two chiefs or ealdormen from Jutland, Hengist and Horsa, who came at the invitation of the civilized Britons to fight in alliance with them against the barbarous Picts of Scotland, and the equally troublesome Scots of Ireland.

The alliance was successful in its primary object, and the Jutes received the Isle of Thanet as their reward. Quarrels ensued between the new comers and their allies, who a few years later swarmed across the Wantsum, undertaking a war of conquest in which the original inhabitants were either slaughtered or dispossessed, the whilom rovers of the sea settling down on the land with their families and all their national institutions. This process, it may be noted, was repeated at each subsequent irruption.

Legend hath it that the Jutes also made a descent on the Isle of Wight, and that the mainland opposite fell into the hands of Hengist-Hengistbury Head on the coast of Hants marks one of the natural "gateways of England" used by the early raiders, Teutonic and Danish. 
In the year 477 an expedition of Saxons, inhabitants of Holstein, set out under the chieftain Ella, and succeeded in establishing themselves in Sussex, by capturing the fortress of Anderida, near Pevensey, the most thoroughly Romanised part of Britain. Eighteen years later another Saxon force, led by Cedric and Cynric, passed up Southampton Water, and founded the kingdom of Wessex.

The East Saxons landed in Essex, in the valleys of the Colne and Stour, captured Colchester, but could make little or no headway, a great forest (of which Epping and Hainault are remnants) hemming them in, just as the conquerors of Kent were cut off from the west by the impenetrable belt of the Andredweald forest, the same barrier which also limited the kingdom of Sussex to a narrow strip of coast land.

A third Teutonic tribe, the Angles of Schleswig, then joined in the migration. They came in several great hordes, the main division under Uffa descending on the east coast and establishing the kingdom of East Anglia. One band settled in Suffolk, another in Norfolk, while a third sailed up the Witham to Lincoln where their settlement became known as Lindesey (Lindis-waras, " the dwellers near Lindum "). Almost from the first these settlers overflowed into Cambridge.

Previous to this another horde had landed at Holderness, north of the Humber, and in less than half a century had made themselves masters of all Yorkshire, founding the kingdom of Deira.

Still further north, a fifth horde of enterprising Ang es, under Ida, " the flame-bearer," sailed up the Forth to the site of Edinburgh, and conquered a large territory which became the kingdom of Bernicia, having the mighty coast fortress of 


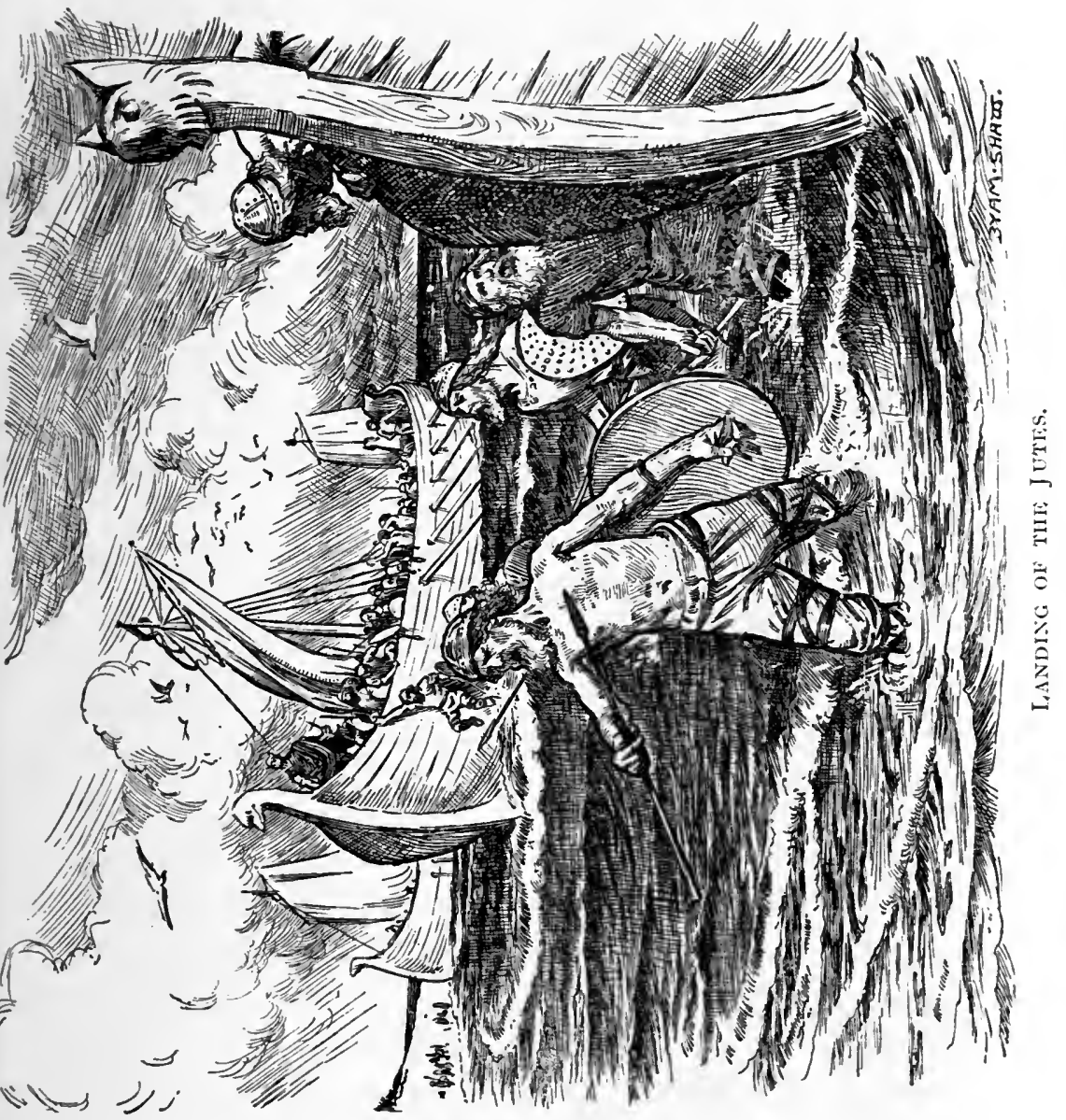



Bamborough (called after Bebba, Ida's wife) as its stronghoid.

The last party of invaders, also Angles, made their descent under a leader named Cridda, in 586, and finding the coastlands already appropriated, pushed their way up the Trent into the heart of the country, overran the northern and western midlands, where they founded a kingdom called Mercia, that is, the land of the merc, or march; thus completing the Conquest begun from Wessex by Ceawlin in 577 .

This, which was the eighth and last kingdom of the Heptarchy, lay between the Thames and the Humber, and constituted the merc or boundary between the English and the free unconquered Britons of Wales.

Before the close of the sixth century, the process of consolidation had commenced-it began with the Angles of the northern territories.

The country between the Humber and the Tees was erected into the kingdom of Deira in 560 ; the portion north of the Tees was established as a kingdom in 547 , by Ida, both territories being eventually united with the name of Northumbria under one monarch.

Northumbria stretched almost from the Trent to the Forth, when its mother-town Bamborough, was in the heyday of its pristine strength and importance-

King Ida's Castle, huge and square.

It was "Ida the flame-bearer"-flames for the houses and churches, the barns and the steadings-who led the fierce Northumbrians across the land, almost to the walls of Chester, while the vanquished Britons retired to their fastnesses in the Pennine Hills. And soon after 
this, Edinburgh was founded by Edwin, and the Northumbrian kingdom flourished mightily.

From Ida, first king of Bernicia (547) and Ella, first king of Deira (560) there were seven short-reigned rulers till 593, when the two states were united under Ethelfrith, first king of Northumbria. Then came Edwin, after whose reign the provinces were again divided, to be re-united temporarily in 634 under Oswald. In 634 Oswy began to reign as ninth king of Bernicia, and when Adelwald, fourth king of Deira died in 670, he seized the empty throne and became fourth king of Northumbria. After its twenty-first king had reigned some twenty years, Northumbria became subject to Wessex, and ceased to have a separate existence.

With the advent of Christianity, a missioner, having converted a Saxon king, was allowed to set up his bishop's stool in the capital, and thus it came about that each original diocese was coterminous with an ancient kingdom.

Durham, in origin and history, stands unique, in that its ancient boundaries do not preserve the rough outline of a kingdom, or any other area of civil government. Durham is a bishop's shire, a diocese made into a county, with the bishop paramount in all things. When the heathen Danes destroyed the religious settlements on the sacred isle of Lindisfarn, the relics of the good St. Cuthbert were carried away, and for safety eventually deposited at Durham.

And after many wanderings past
He chose his lordly seat at last
Where his cathedral huge and vast
Looks down upon the Wear

Durham, a noble site upon a bold, rocky promontory, enfolded by the winding river, became 
at once a temple and a fortress. To this transferred shrine the Northumbrians paid all their reverence, brought all their offerings. By degrees the new settlement became supreme over all the country round; grants from kings and thanes confirmed the authority of the bishop.

Let it be understood that the present line of demarcation between England and Scotland had no existence. On the eastern side the Anglican kingdom of Northumbria stretched from the Humber to the Forth; on the western side, the British kingdom of Strath-clyde (or Cumbria, south of Hadrian's Wall) reached from the Mersey to the Clyde, with Dumbarton as its capital.

When the Romans left the island, the tribes occupying the country between the two walls had formed themselves into the kingdom of Strathclyde. This state comprised (on the north side of the present border) the counties of Ayr, Lanark, Renfrew, and parts of Dumbarton, Stirling, and Dumfries.

The belated definition of the northern counties naturally arose from the later period at which it was attempted to fix a line of demarcation between a united England and a united Scotland. Of which, more anon. In the meantime we return to the Saxon kingdoms of the South.

When London, the richest and most populous sea-port, was attacked and occupied, is not precisely known-probably about 568 . The West Saxons had extended themselves from Hampshire to Gloucestershire, overrun Wiltshire, Oxfordshire, Berkshire, and the valley of the Severn, almost reaching Chester; after storming the huge fortress of Old Sarum, they destroyed Silchester which commanded the road to London, and suddenly found themselves at Wimbledon face to face with 
the Jutes of Kent, who had edged their way westward between the forest and the Thames. A battle ensued, the Kentish men were forced back, and the West Saxons remained masters of the south midlands.

British influence largely disappeared in the mastered territories, those who escaped death fleeing to their brethren in Cornwall or Wales. A line drawn along the Pennine chain to Derbyshire, through the forest of Arden to the mouth of the Severn, and thence to Southampton, marked the limits of the Teuton conquest up to the year 600. All west of that line remained British. For with each successive wave of the incoming Teutons, the Celts had retired further before them, taking refuge in the more mountainous regions of the west -in Wales, Cornwall, and Cumberland.

The main body of the British in Wales were cut off from their brethren in Cornwall by the West Saxons in 577 ; in 613 the Northumbrians broke through the British march, fought their way to Chester and thus cut them off from the northern section in Cumbria. It was a great battle in 577 at Deorham, near Bath, which cut off the two principal British settlements from each other, after which the West Saxons left the lower Severn valley to the tribe of Hwiccas, working their way up the Avon into Warwickshire. The Hwiccas may possibly have been an outlying tribe of the West Saxons who had intermarried with the British; when the see of Worcester was founded, the Bishop was to be designated "Bishop of the Hwiccas," and his diocese included the counties of Worcester and Gloucester, together with some of the adjacent district. At the outset there were nine or ten Saxon kingdoms; Middlesex soon ceased to exist, and Deira and Bernicia were 
generally governed by one ruler as Northumbria. The pure Saxons established themselves into the three kingdoms of Essex, Sussex, and Wessex; these afterwards federated under a Bretwalda, or "Wielder of the British," chosen from one of their kings. From a ducal Bretwalda, to a sole king of all the united sub-kingdoms, was but a step in political progression.

The rank of Bretwalda arose out of the need for a common leader against the Britons, Picts, and Scots. The first was Ella of Sussex, the second Ceawlin of Wessex, and the third, Ethelbert of Kent, the King who was converted to Christianity in 597 by St. Augustine.

The next Bretwalda was Redwald, king of East Anglia; the fifth and greatest was Edwin, whose authority was acknowledged by all the AngloSaxons, except those of Kent.

Edwin fell in battle, fighting against Penda, the pagan king of Mercia ; who in turn was defeated and slain by Oswy, king of Northumbria, and sixth Bretwalda, in 656. Then Mercia, successful against the Britons of the west, became the leading state, uniting under its standard East Anglia, Essex, Kent, and for a while also Wessex. Ethelbald of Mercia, in a charter of the year 736 calls himself " King of Britain." After the death of Offa, king of Mercia, the builder of a dyke from the Dee to the Wye, to keep back the Welsh, Mercia began to decline.

To Wessex was reserved the achievement of bringing all the Anglo-Saxon states under one crown. Egbert, eighth Bretwalda, wrested from Mercia the tributary kingdoms of Kent and Sussex, took under his protection the revolted East Anglians, and completely overthrew Mercia. To all these Egbert granted the power of electing 
kings tributary to himself, and soon after received the submission of Northumbria on the same footing. By 827 the country was virtually united, the minor kingdoms having merged their identity into that of Wessex, so that Egbert styled himself " King of the English."

Varying fortunes of the contending kingdoms altered their boundaries from time to time, and even their number, as the more powerful absorbed their smaller neighbours. The Jutes (or Goths) were the first comers, though the less numerous of the three invading tribes. The Angles came in such hordes that they completely evacuated their native land, and left it uninhabited.

Though in the end a Saxon kingdom prevailed, it was the dialect of the Angles, who had filled the middle of the country, which came to be used. It is indeed remarkable that while the people of the entire south called themselves Saxon-as witness the names Essex, Sussex, Middlesex, Wessex-they never called themselves in literature or records by the name Seaxisc, but always Englisc.

It is now disputed that the name of this country was elementally " the land of the Angles." It is contended that the word England was derived from the nature or character of the country inhabited by them.

The root of the name is given as "Enge," the Norse name for a meadow. Until the latter half of the tenth century the southern parts of England were known as Wessex, Essex, Sussex, Middlesex. Freeman in his " Norman Conquest" (Vol. I) writes : " Indeed England itself was hardly a geographical name. Enghalaland is a late form, scarcely found before the Danish Conquest. The common name for the land is the name of the 
people Angel-cyn "-in other words, the meadowland folks.

When the Norsemen overran and conquered England in the tenth and eleventh centuries they were struck by the extent and richness of the pasture-lands of Yorkshire and Central England, and called it Enge-land, that is, meadow-land.

The confusion of Enge-land with Angle-land may have arisen from the fact that the district so-named was really occupied by Anglians. For till then the Angles and the Saxons had really stood apart, and remained distinct from each other, the former holding the north and the east, the latter occupying the south and the west.

The Angles were the first to produce a cultivated book-speech, which accomplishment so excited the admiration of their southern neighbours that they emulated the Anglian example, and the common language which emerged came to be called Englisc, after the inventors of it.

It was 400 years from the first Teutonic invasion to the foundation of a united England ; Winchester was adopted by Egbert as its capital, although Alfred recognised the greater importance of London.

The original Saxon capital retained its position till after the Conquest, and Henry II was crowned at Winchester, although by this time London was fast superseding it as a court residence, and the seat of governmental functions. But no capital, wherever situated, could make its voice articulate or its authority felt, till the relationships of all tributary and subordinate territories had been placed on a definite footing.

When the Heptarchy was merged into one united kingdom under Egbert in 827, few of the heptarchical divisions, as Essex and Sussex, became 
counties at once, while the rest of them, as will be seen, were in due time divided up till they constituted the forty English shires as we know them to-day. Wales being unconquered territory, was left out of this arrangement for a long period, even after its conquest by Edward I.

The arrogant attitude which the Anglo-Saxon conquerors assumed towards the original owners of the soil, is amusingly illustrated by the name by which they designated their victims. Having first unceremoniously dispossessed the Britons of their lands, the intruders dubbed them Wealas -that is, " strangers "-and as Wealas, or Welsh, they are to this day known in the land which was once their own.

Unquestionably a large native population must have been left in the conquered portion, and these would appear to have been gradually absorbed by their conquerors; the majority of these no doubt in a servile position, and all of them in close subjection.

A careful study of English Place-names disposes of a theory, once so largely held, of the original equality of the early inhabitants. It emphasises, too, the character of the first AngloSaxon forms of land tenure, and seems to indicate the early existence of a type of agrarian community from which the manorial system was gradually evolved.

As the story of the shires unrolls itself, it will be recognised as the manifestation of the Englishman's genius for local self-government. The shire system of England spread at a comparatively early period into Scotland, Ireland, and Wales.

At various later periods we get sprinklings of other peoples. The Norman Conquest brought in a mixed multitude from the continent; the wars 
of Stephen's reign introduced a numerous body of Flemings who were by Henry II. settled in Wales; and a little later a still larger body of the same people were brought in by the commercial views of Edward III. and located as cloth-workers in Kent and the eastern counties.

However mixed the Englishman's origin may have been; and notwithstanding that De Foe has said that

With easy pains you may distinguish

Your Roman, Saxon, Danish, Norman-English-

all these varying elements have modified but very slightly the national character, the dominant feature of which, from the day our first Teuton ancestor landed, has been a love of liberty and a passion for self-government. And this has always been expressed in the autonomony of the local unit.

Though various races have contributed to populate this island, the chief contribution, made well within the historic period, is from a Teutonic source; large colonies of the Saxons and Jutes establishing themselves from Kent to Devonshire, and the Angles (subsequently the Normans also) from the Thames to the Tweed. It is the Tuetonic ideal of self-government that has always prevailed.

The Romans, who occupied the country more as a permanent garrison than as a body of colonising settlers, are altogether a negligible element. By the Danes or Norsemen a very considerable contribution was made; but in many characteristics they were scarcely dissimilar from the Saxon settlers with whom they freely mingled and intermarried. 
Throughout the centuries, whatever people or race have found their way to the shores of this country, to remain here and "dwell within the gates" with us, have inevitably been absorbed and assimilated into the nation; finding here

\section{A land of settled government \\ A land of just and old renown \\ Where Freedom broadens slowly down \\ From precedent to precedent.}

And not the least remarkable feature in our national life has been the self-assertion expressed in our settled form of local government, which has always enjoyed comparative freedom from the thralldom of a central authority.

The tendency for centuries has been for each shire to exploit its own vitality, to cherish its own traditions. Everywhere local patriotism and civic independence have gone hand in hand, the operation of the shire system tending towards variation and individuality, and not to that dreary uniformity of social life which robs it of half its strength. It was surely the characteristic ineptitude of a centralised bureaucracy that, during the recent great World War, neglected to take advantage of the ardent spirit of territorialism, and allowed the War Office to recruit a Lancashire regiment with Cockneys, and to draft Dorset men into a regiment of Borderers!

No topographer can afford to ignore the subtle yet unmistakeable characteristics of the counties which set them apart from each other. In the old days each county was a little kingdom, and all outside it was " foreign."

The march of progress and easier communications are fast obliterating these distinctions, but as nature is in them as well as man, and as parts of remote rural England have not altered so 
enormously since Domesday, many remain to rejoice the true topographer, who knows that in the country little things go a long way back and mean much.

A disposition to reverse the practice of centuries, and to centralise the whole government of the country in London, as that of France is in Paris, first began to manifest itself here in the latter half of the nineteenth century. The result has been described as "the chaos of local government." As early as I888, the Rt. Hon. Joseph Chamberlain, while at the Local Government Board, diagnosed the evil with statesmanlike sagacity, and strenuously opposed any addition to the controlling powers of his department-had he not been himself trained in the school of local politics? The truth has since come home to other statesmen, particularly in the education department, that it is better to rely on local experience than to enforce a national uniformity. Everywhere bureaucracy has been a failure, and happily the tendency now is to go back to the good old English custom and " trust the people."

The policy of the future will be the policy of the past - to increase the functions of local authorities, to co-operate with them, and to free them from the shackles of centralisation.

English freedom, liberty of thought, liberty of speech, liberty of action, the freedom of English institutions, are not a little attributable to its ancient system of local independence. It was an organisation by which each locality became as a matter of course, lively and articulate.

This is the spirit of the English constitution, says that patriot statesman, Edmund Burkeand he was speaking of that same spirit carried across the Atlantic to the new States then arising 
in the far west-." which, infused through the mighty mass, pervades, feeds, unites, invigorates, vivifies every part of the empire, even down to the minutest member."

" The sovereign authority of the country," says the orator, is kept by " the chosen race of the sons of England," wherever they make their home, as a sacred temple consecrated to their common faith-the Liberty of the Subject. 


\section{II}

\section{BRITISH TRIBAL AREAS.}

Before entering upon the story of the shires, it may not be out of place to make a digression here, in order to obtain some faint idea of the divisions into which this country was apportioned among its earlier inhabitants, the Ancient Britons.

Even in those primitive times, when the surface of the country was nearer the earth's primeval state of dense woods, impervious marshes, and undrained fenland, political boundaries did not remain constant. This fact becomes apparent when we find the various writers upon whom we depend for our knowledge of those far-away times, giving different lists of the tribal areas of the Ancient Britons. We have to remember they wrote at different periods.

When the Romans came to this country, just before the Christian era, they found it in the possession of a Celtic population akin to the Gauls of France, and like them split into numerous tribes, the mass of the people in a state of serfdom, the slaves of two dominant classes, the priests (called Druids) and the chiefs of military clans.

After the termination of the first hostilities, treaties of agreement had to be made with the Trinobantes of Middlesex and Essex, whose young chief was restored (as a Roman tributary) to the sovereignty which had been usurped by Cassivelaunus, the talented leader who had led the Britons 
against the Roman invaders, and whose capital was probably St. Albans, in the territory of the Cassii, a Belgic tribe, probably the same as the "Catycuchlani" of Ptolemy.

Another city of Romano-British origin in this part of the country was that near Basingstoke in Hampshire, called by the Britons Cær-Segant, and by the Romans Segantiaci; afterwards it was known to the Saxons as Silchester.

The example of the Trinobantes was immediately followed by other tribes; the Iceni or Cenimagni (of Norfolk and Suffolk), the Segontiaci (Hampshire and Berkshire), the Ancalites (Middlesex and Berkshire), the Bibroci (Hampshire, Berkshire, Sussex, Surrey and East Kent), and the Cassii (of Hertford, Bedford, and Buckingham). All these bargained for protection against the aggressive Cassivelaunus, whose kingdom centred in Hertfordshire. Julius Cæsar was thus master of a considerable territory, which completely surrounded the country of the Cantii (Kent), where he had first landed. And if we are to accept Shakespeare as an authority-

Kent, in the commentaries of Cæsar writ,

Is termed the civillest place of all this isle.

(Henry VI. Part 2).

The Celts had come to Briton in two separate bodies, and at two different periods. No one can say when the first horde, known as the Goidels, crossed from the Continent, but certainly centuries before the Brythons or Gauls, who when they arrived later drove them westward.

When the Romans appeared on the scene, the Goidels were found occupying the three western peninsulas of England, the Cambrian, the Cumbrian and the Cornish, except for a wedge driven in between North Wales and South Wales by a 
Brythonic tribe called the Ordovices. South Wales was occupied by the Demetæ and the Silures (the latter extending at first from the Dee to the Wye) and the Cornish peninsula by the Damnonii, having on their inland or north-eastern borders the Durotriges, whose territory stretched from the Bristol Channel to the Isle of Wight within the well-defined limits of the Mendips and the River Stour.

It is quite clear the island was inhabited by two distinct races, differing perhaps to some extent in language as well as in manners. The coast-lands extending from the Humber to Devonshire, and stretching inland as far as the modern counties of Hertford, Buckingham, and Berks, were occupied by the tribes who had last crossed from the continent and driven the aboriginal inhabitants westward. They were distinguished by a much higher civilization - they had permanent habitations, while the others wandered all over the interior, and the western highlands, driving their flocks and herds before them.

It may be accepted that the southern and eastern parts of England derived the main portions of their population from Belgic Gaul, while the western districts and Wales were probably peopled from the west of France and the north of Spain. The earliest peoples of both Ireland and Scotland may also have been originally Belgic.

Northward of the Tyne wandered the Maetæ, and north of them the Caledonii, together known as the Picts.

It will be seen that practically the whole of England proper was held by the various tribes of Brythons (otherwise Britons), the north central part, stretching from the sources of the Trent to the mouth of the Tweed, 
being inhabited by the Brigantes, who were flanked on the Lancashire coast by the Segantii, and on the Yorkshire coast by the Parisii. Eastward of the Ordovices, the Midlands were occupied by the Cornavii, divided by the Trent from the Coritani whose territory stretched thence to the Wash. East Anglia, we have seen, was held by the Iceni, Essex by the Trinobantes, and west of these were the Catuvillani. The Thames valley was occupied by the Attrebates, and between the sources of that river and the left bank of the Severn came the Dobuni. Kent was the country of the Cantii, divided by the Forest of Anderida from the Regni. Lastly, along the south coast came the Belgæ whom Cæsar distinctly says differed in language and customs from the Celtæ.

As already noted the most civilized of all were the people of Cantium (Kent), whose manners bore strong resemblance to those of their Gallic neighbours. The maritime districts were essentially corn countries, agriculture having been introduced by the Belgic settlers. The wild tribes of the interior did not till the soil, but lived on milk and flesh and clothed themselves with skins. Cattle were abundant, though the art of making cheese was unknown. All the Britons stained themselves with a blue dye made from woad, to give them a more terrible aspect in battle ; they wore their hair long, and shaved every part of the body but the head and upper lip.

The Goidels or aboriginal Celts were tall of stature and corpulent, but not well made. They practised polygamy. Their dwellings were temporary establishments formed in the forest by inclosing a space with felled trees, within which they made huts of reeds and logs, and sheds for 
the cattle, " not intended to remain long" says Diodorus Siculus, the Roman historian. Those who practised agriculture, he describes as gathering the corn, storing it up in the stalk in thatched houses, out of which " they plucked the old ears from day to day, and used them to make their food."

Strabo, the geographer; informs us that those who lived near the Bolerian promontory (the Lands' End, Cornwall), were more polished in manners, and hospitable to strangers, to whom they were more accessible than those of the interior since they had some small intercourse with the outer world by sea.

Both authors quoted describe the country as for the most part flat and very woody, with " many strong places on the hills."

The produce consisted of corn and cattle, gold, silver, and iron, with skins, slaves, and dogs of a superior breed for the chase. The inhabitants of Cornwall worked mines of tin, and showed skill in preparing the ore, which they conveyed to Vectis (?Wight) where it was purchased by merchants who transported it to Gaul.

The Isle of Wight was called by the British Guict, signifying " divorced " or " separated," from which arose the appellation of Vectis, or " separated region," for this island. In the days of Diodorus it was only disjoined from the mainland by the tide, and was united to it sufficiently at the ebb, by a gravelly isthmus, to allow carts of tin to pass over it.

Whatever there was of British intercourse with the outer world, there exists not a scrap of evidence, linguistic or other, of the presence of the Phœnecians in Britain at any time. The tin of the Damnonian peninsula certainly found its way 
to the continent, it may have been through the Isle of Wight, though not improbably via the Isle of Thanet.

A survey made by a Roman geographer about the beginning of the second century, shows Kent still occupied by the influential Cantii; Sussex and Surrey by the Regni; Hampshire, Wiltshire, and Somersetshire by the Belgæ; Devon and Cornwall by the Damnonii ; Dorset by the Durotriges; Middlesex and Essex by the Trinobantes; Suffolk, Norfolk, Cambridge, and Huntingdon by the Iceni ; Northampton, Leicester, Rutland, Derby, Notts, and Lincoln by the Coritani or Coritavi; while the south-eastern portion of Yorkshire was held by the Parisii.

Between the tribes last enumerated, in the counties of Buckingham, Bedford, and Hertford, lay the tribe called the Catuvellani, another name for the Cassii, or a division of it. In Berkshire, west of these, were the Attrebates, and still further west in Oxon and Gloucester, were the Dobuni.

Coming to the interior of the land and northward, the extensive district, difficult of approach on account of mountain and wood, reaching from the Humber and Mersey to the present borders of Scotland, was occupied by the Brigantes, believed to be the original inhabitants of the country. This powerful and predatory tribe included several smaller ones; the Voluntii occupied the west of Lancashire, and the Sestunii inhabited Westmoreland and Cumberland. The Jugantes and the Cangi, on the shores of the Irish sea, belonged to, or were dependent on, the Brigantes.

A later writer gives a list of the Belgic colonists who settled in the south-eastern portion of the country, associating the Hedui with the locality of Somersetshire, the Morini with Dorset, the 
Senones with Hampshire, the Rhemi (probably another name for the Bibroci) with Berks, Sussex, and Surrey, the Attrebates with a strip of territory stretching from Surrey into Hants, the Cimbri with the borders of Devon, and the Parisii with the north-east coast. Some of these names we have noted before; those that are new are probably duplicates, or the names of subdivisions. Anyway it should be remembered that all these names were conferred on the various tribes by foreigners and strangers to them.

But it is interesting to trace in the names of some of these Belgic tribes the localities on the continent with which they were originally identified. The Attrebates came from the region of Artois, the Cimbri from Cambrilla, the Rhemi from Rheims, the Senones from Sens, and the Parisii from Paris. Place-names do occasionally yield evidence in this way of the migratory movements of a people.

Wales continued to be inhabited by its primitive population. The northern counties of Flint Denbigh, Montgomery, Merioneth, and Cærnarvon, with the island of Anglesey (then 'called Mona), was the territory of the Ordovices. The southwestern counties, Cardigan, Carmarthen, and Pembroke were held by the Demetæ; while the still more celebrated tribe of the Silures occupied the modern counties of Hereford, Radnor, Brecknock, Monmouth, and Glamorgan. Between these and the Brigantes lay the Cornavii, who inhabited the territory now filled by the border counties of Warwick, Worcester, Stafford, Salop, and Chester, and a part of Flint.

In the versification of Michael Drayton, we have an expository rendering of all this in the lines- 
The Ordovices, now which North-Wales people be

From Cheshire which of old divided was by Dee ;

And from our Marchers now, that where Demetr then

And those Silures called, by as South-Wales men.

The poet, it will be observed, slightly displaces some of the tribes, though fairly correct in the main; as " where the Dobuni dwelt, and their neighbouring Cateuclani." And again in the lines-

Cornavii more remote, and where the Coritani

Where Dee and Mersey shoot into the Irish Sea.

he is scarcely so correct as in the following-

As in that horn which juts into the sea so far,

Wherein our Devonshire now, and farthest Cornwall are,

The old Damnonii dwelt; so hard again at hand

The Durotriges sat on the Dorsetian sand ;

And where from sea to sea the Belgæ forth were let

Even from Southampton's shore through Wilts and Somerset,

The Attrebates in Bark unto the bank of Tames.

So eastward from the Thames the $\bar{T}$ Trinobantes were set

To Trinovant their town, from that their name in debt

That London now we term.

London's earliest name, Troy-novant, is really British, being compounded of Tri-nou-hant, "inhabitants of the new town." Civitas Trinobantum, the city of the Trinobantes, might be rendered New-townsmen. It has nothing to do with the legend that London was founded by Brute, a Trojan refugee, notwithstanding Spenser's lines in the Faery Queen-

For noble Britons sprung from Trojan's bold,

And Troy-novant was built of old Troyes ashes cold.

The spelling of the names of some of the tribes, and their geographical location, must be reconciled as best they may.

It is interesting to note that the names of some of these ancient tribes may be discerned in existing place-names in the localities they once occupied. The name of the Cantii is seen in 
Kent and in Canterbury; of the Iceni in Ickborough (Norfolk), Ickworth and Iken (Suffolk) ; of the Bibroci in Bray (near Windsor), and of the Casii in Cashio, the name of a Hertfordshire Hundred, and in Cashiobury (near Watford) which probably occupied the site of the chief town of the tribe.

The Damnonii are believed to have given their name to Devon, and the Durotriges to Dorset and Dorchester, while the Regni evidently lived around Ringwood (or Regne-wood) in Hants.

The literal signification of these tribal names would be profoundly interesting and, probably, very illuminating, if only they could be arrived at with any degree of certainty.

The name Trinobantes, if not derived from the capital settlement of the tribe, has been said to signify the " battle-spearers" ; and the Ordovices (or Ordovi) are said to have been so-called because originally they were " the hammerers," wielding, in the Stone Age that preceded the Iron Age, formidable axe-hammers of flint. The Iceni, again, were "the men of the small knives," presenting a Celtic parallel to the Saxons who, it is well-known, derived their name from Seaxe, a short sword. Invading hosts were frequently named from the weapons they wielded in battle with most effect.

As the Iceni gave to our history its most heroic queen, the renowned Boadicea, the Trinobantes produced for our literature Shakespeare's hero, Cymbeline. Cymbeline, otherwise Cunobeline, whose father was an ambitious chieftain-

The first of Britain that did put

His brows within a golden crown, and call'd Himself a king-

is said to have had his capital at Colchester. 
The Brigantes are believed to bear a name which (literally) distinguished them as free men and a privileged race, as contrasted with the reduced and servile Goidels under them. It was Cartismandua, queen of the Brigantes, who delivered the gallant Caractacus, king of the Silures, to the Roman invaders. The name Silures is altogether of unknown meaning, though believed to have some relationship to the name Scilly. And all that can be said of Demetæ is that the district they occupied now bears the name, in modern Welsh, of Dyved.

The Attrebates bore a name which, it is said, marked them out in a special sense as the farmers or "homestead men." The Cornavii, it has been suggested, had this name conferred upon them because they occupied the horn, or "corn" headland, between the Dee and the Mersey. This origin is extremely doubtful.

The Coritani (or Coritavi) are said to have taken the name of some pre-Celtic inhabitants who had possibly survived in the inaccessible regions of the Wash, which then reached inland to Cambridge and Northants. The Catuvillani were another aggressive tribe, the Mercians of their day, and paramount among the Celts. 


\section{BRITAIN DIVIDED INTO ROMAN PROVINCES}

At the first coming of the Romans the tribes were sharply divided. Many and great were the changes which came over the native inhabitants of the land after its subjugation.

Their independence was irrecoverably gone, their nationality was lost, and, as they were merged into the Roman Empire, they lost their very names, either as Roman subjects or as Roman slaves.

Not the least of these great changes was the disappearance of the old tribal divisions of the land. Under barbaric rule the boundaries of these divisions had fluctuated as aggression expanded a territory, or subjugation had either obliterated or contracted the tribal delimitations.

The Romans were the first to divide this country into administrative areas; though from the time of its conquest, down to the year I97 A.D., they governed it as one province, and did not, as they had done with Spain and Gaul, divide it into three or four separate territories. It is noticeable that while the people of Spain became cultivated Roman citizens, the Britons remained rude boors.

Britain was one of the provinces administered by the Emperor's deputies, not by an officer of the Senate ; and the governor's full title was Legatus Augusti pro pratore, or Viceregent of the Emperor. Being a province that required military 
occupation, Britain was not committed to a Pro-consul chosen by the Senate, but to a Proprætor nominated by the Emperor. In other words, it was "Imperial" as opposed to "Senatorial."

The governor of Britain, however, was not a mere rough soldier, but generally a man of some education, capable of administering the law and conducting the affairs of state, besides commanding the military forces of the province. By his side was an officer called a Procurator or Quæstor, who took charge of all financial matters, and administerd the revenues of the country.

After the year I97, Britain was divided into two provinces by a boundary line, which was not improbably drawn between the Mersey and the Humber; the southern half of the Country being designated Britannia Superior, and the northern half Britannia Inferior, these distinguishing terms having reference to nearness to Rome. Although it is not known in what towns the respective Governors took up their official residence, the weight of evidence is largely in favour of London and York.

Presently this arrangement gave way to an organization of four districts or provinces, Britannia Prima, Britannia Secunda, Maxima Cæsariensis and Flavia Cæsariensis, to provide which with physical frontiers the Thames, the Severn, and the Humber were very probably called into use.

The first of these lay south of the Thames and the Bristol Channel ; the second corresponded with the modern principality of Wales; Flavia comprised the middle of the country, from the Thames to the Humber and Mersey ; and the country beyond this, to some twenty-five miles north of Hadrian's Wall, formed the department of Maxima 
Cæsariensis. At a later period (A.D. 369) a fifth province called Valentia was added, stretching northward from the Tyne to the Forth.

Towards the end of the Roman period, when the enemies of the empire were closing in on every side, three high military commanders were appointed, independent of the authorities in Britain, but subject to the Gallic præfectus ; they were the Duke of the Britons, the Count of the Britons, and the Count of the Saxon Shore, the last-named having the defence of the south-eastern coast in his special charge.

The Saxdn Shore comprised the coast of Norfolk, Suffolk, Essex, Kent, Sussex, and Hampshire; castles with garrisons under the command of Comes Littoris Saxonici per Britanniam were situated at Brandcaster (Norfolk) Burgh (Suffolk), Ithanchester (Essex), Reculver, Richborough, Dover, Lymne, (Kent), Pevensey and Worthing, (Sussex). The remains of some of these castles, and of the Roman walls in the north, are a few of the reminders of the sway once held by imperial Rome in this island. Hadrian's Wall, between the Solway and the Tyne, marked the northern limits of the province in the year I2O. This wall was the beginning of the division of Great Britain into the two parts now known as Scotland and England.

Subsequently, but for a very brief space, the old British kingdoms were united under one chief, called Pendragon, who claimed to represent the Roman Emperors.

It will be seen that for some considerable time before the Roman evacuation, piratical expeditions had harried the coasts of the country, and that settlements had even been effected. After the Roman withdrawal the Teutonic marauder was merged entirely into the settler. 
In considering these early settlements physical barriers and other natural features must not be lost sight of. 'Thus, the first great settlement, which was made in Kent, was bounded by the dense forest which the Romans called Anderida; and here the Jutes were practically shut up in a single county; for by the time they made their second landing, in Hampshire, the other tribes settled round about were too strong for them.

Later, when the Angles attacked the east and north-east coasts, they penetrated into the midland districts but slowly, and that by sailing cautiously up the rivers; for at that period there existed a great belt of swamp and marsh of which the Fens are but now the merest remnant. The river valleys, too, were found by the Saxons who landed in Southampton Water, to be the easiest, if not the only avenues into the heart of the country.

These invaders, whatever their tribe, were a bold and sturdy people, of a free and enterprising spirit. Yet of their previous history our knowledge is strictly limited, notwithstanding that their habits and customs and their established laws, came to exercise such a far-reaching influence over the destinies of this country. It is manifest that, as they came with their wives and families, their intention was not so much to govern the Britons as to exterminate or subdue themto deprive the natives of their land, which by comparison with the district round the Elbe from which they came, with its barren marshy soil and its chilly damp climate, was a rich and inviting country. 


\section{IV}

\section{ENGIAND DIVIDED INTO SHIRES.}

Though Alfred the Great is generally credited with the division of the country into shires, it is certain these territorial divisions were known long before his day, being mentioned in the laws of King Ina, a century or more before the consolidation of England into one realm under one king. The probability is that Alfred rectified the boundaries of a number of them.

The smaller kingdoms and their sub-divisions fell naturally into shires; as Kent and Surrey, Norfolk, and Suffolk, Essex and Sussex. At what time the complete distribution of the country into shires was effected is not known, but nearly all of them had been called into existence before the Norman invasion.

Freeman, the historian, makes an exception of Lancashire, which he says, did not exist as a shire at the Conquest. In IO7I the northern portion was included in Yorkshire ; and the southern part, between the Mersey and the Ribble, had been vested in the crown under Edward the Confessor, and held of him by a number of petty thanes.

Ina, the greatest of the early kings of Wessex, in 693 formulated, for the good governance of the West Saxons, a Code of Laws, the thirty-sixth of which distinctly mentions the earldorman as the governor of a shire under the king.; the ordinance is to the effect that if he lets a captured thief escape, or hushes up the crime, " he shall lose his shire." 
The first Wessex ealdorman mentioned by name is Cumbra, who ruled "Hamtunscire" (Hampshire), for king Sigebert, a tyrant, who rewarded his fidelity by slaying him (A.D. 757).

Wessex included Hampshire, Wiltshire and Berkshire, and also perhaps Oxfordshire, although it was on the north side of the Thames. Somerset and Dorsetshire were long included in Celtic Damnonia, which comprised Devonshire and Cornwall, only rominally in Wessex, and in reality mainly Welsh. Not till 926 was the king of the Cornwelsh driven back beyond the Tamar. A trace in the delimitations of the two races may be found in the loop of Devonshire on the west side of the Tamar, none of the place-names being Cornish, but commonly ending with the Saxon terminal " cot."

All the shires of Wessex, save Devon, appear to have been created before the reign of Ina. These shires may have been the successive local units created by each advance of the Wessex border at the expense of the Welsh; colour is given to this theory by interpreting the names Wiltshire, Dorsetshire, Somersetshire, as indicating the regions in which bodies of settlers called Wilsætas, Dornsætas, and Somersætas took up their abode, and gave their names to their respective settlements.

Another view of the origin of shires regards them as representing, more or less, the realms of the numerous sub-reguli who parted Wessex among themselves on several occasions during the seventh century. This theory would certainly hold good with regard to Berkshire, which most probably represents a principality of three thousand hides which king Cænwalch is known to have granted to Cuthred "in Ashdown." 
Under the latter hypothesis the ealdorman would be a royal official appointed to administer what had formerly constituted the realm of a sub-regulus, from its most important centre. In agreement with this theory, the shire names of Hampshire, Wiltshire, Dorsetshire and Somersetshire, would then be traced back to the royal "vills" from which they were respectively administered, namely Hamton, Wilton, Dorchester, and Somerton.

It is noteworthy that in the other English kingdoms which were large enough to require administrative ealdormen, Mercia and Northumbria, no trace can be found of this early shire system, with its sheriffs, and other necessary officials.

In Mercia there were certainly ealdormen who governed districts for the king, but they were much more extensive than the Wessex shires. The Mercian ealdormen seem to have ruled the old sub-kingdoms, in succession to the sub-reguli, who died out in the eighth century. When the Mercians were supreme in the eighth century, it is noteworthy that they held : way in London, when that great imperial city was being engrafted with Anglo-Saxon forms of local government.

It may be inferred from a statement in the Anglo-Saxon Chronicle that in the following century there were at least five administrative districts in Mercia under ealdormen-these distinct from the vassal kingdoms of Mercia, like Kent and Essex, under duces, as they signed themselves in various charters. These administrative districts were those of Hwiccia (the lower Severn valley, formerly ruled by a line of native kings ;) the Magesætas beyond the Severn to the line of Offa's Dyke ; Lindsey, be- 
tween the Humber and the Wash; the Middle Angles, directly inland of East Anglia; and Mercia proper. Possibly there were two other administrative units under ealdormen - the Gyrwas, on the Fenland border (Cambridgeshire, North Northamptonshire and South Lincolnshire) ; and the Chilternsætas, lying north of the middle Thames.

Mercia at one time or other comprised the area now occupied by Staffordshire, Derbyshire, Nottinghamshire, Leicestershire, Northamptonshire, Rutlandshire, Warwickshire, Gloucestershire, and Worcestershire: possibly also parts of Bedfordshire, Buckinghamshire and Oxfordshire. For a long time the Severn was its western boundary, and till a comparatively late period Shropshire and Herefordshire were in the Welsh marches, and under Welsh rule. Monmouthshire, in the basin of the Usk, was not made an English county till the reign of Henry VIII (I535) and remains to this day more Welsh than English.

Gloucestershire and Worcestershire do not exactly reproduce Hwiccia, which had embraced a part of Warwickshire along the Avon, and had not included the Forest of Dean, which was in the ealdormanry of the Magesætas. Gloucestershire was no doubt formed of lands attached to Gloucester and Winchcombe (there was originally a "Winchcombeshire," which Eadric Streone, the infamous ealdorman of Mercia, who was executed by Canute, arbitrarily annexed to Gloucestershire); Worcestershire, of lands attached to Worcester; Herefordshire, of the area round Hereford; Warwickshire of lands governed from Warwick Castle; Staffordshire, of the burghal hidage attached to Stafford; and Shropshire, of lands belonging to Shrewsbury. Salop com- 
prises a portion of Mercia only as to two-thirds of its area, its southern third having been Magesætan soil. Oxfordshire, which was formed round the government of Oxford, stretched beyond the limits of old Mercia.

The formation of the west-midland shires came much later, and seem to have been administrative districts which crystalized around certain of the burghal centres created by the warlike Princess Ethelfleda (daughter of Alfred the Great, and widow of Edward the Elder) or older centres like Chester. It cannot be discovered that they were honoured, on their formation, with an ealdorman apiece. The first to be mentioned by name is Cheshire, in 980 ; and none of them, from this county to Oxfordshire, had boundaries which coincided with those of the older Mercian ealdormanries.

South Saxonia was made up of Sussex and Surrey; East Saxonia, of Essex, Middlesex, and Hertford, and in ancient times took in part of Bedfordshire. Kent, as a Saxon kingdom and a modern county, is practically identical.

East Anglia contained Norfolk and Suffolk, Cambridgeshire and Hunts; and as a rule, Lincolnshire, though at odd times it belonged to the Mid Angles of Mercia. Of Rutland, as a distinct county, no mention is made till the fifth year of King John, at the coronation of whose queen, Isabel, it was (with other lands) assigned for her dower. Till this period it was a crown manor merged in the neighbouring counties of Northampton and Nottingham.

In the eastern regions, which had come under Danish influence, the title of Earl began to appear, and evidently indicated the high dignitary who on purely English soil would have been designated ealdorman. 
By the year 930 there were no less than thirteen earls bearing Danish names, evidently Danish magnates holding territorial jurisdictions in Northumbria, East Anglia, and the east Midlands, all of them probably " jarls" who, having submitted to Edward the Elder, were graciously given, or confirmed in, their official positions.

Though there was an ealdorman for every southern shire when Edward came to the throne, by the end of his eldest son's reign there were only three or four south of the Thames, a system of grouping, probably for military purposes, having been commenced by Edward and completed by Athelstan. A unit of three shires, as Somerset, Dorset, and Devon, or Hants, Wilts, and Berks, would be more conveniently handled by one ealdorman than three; and its levies got together more effectively under one leader, a matter of some consideration when the Dane-law was but newly subdued.

As to Northumbria, there were certainly ealdormen therein, though without any visible trace of the shire system. These officials are styled Highreeves in the Anglo-Saxon Chronicle; they exercised as much power as a sub-regulus, and their office was apparently hereditary, as one family of such High-reeves can be traced at Bamborough for several generations. Though this characteristically Anglo-Saxon administrative system flourished in the north during the seventh and eighth centuries, it was entirely swept away by the Danes in the ninth.

Northumbria contained Northumberland, Yorkshire, and Durham, and anciently stretched to the Firth of Forth. The races who occupied Mercia and Northumbria can only be described as mixed Anglo-Celtic. 
Cumbria comprised Cumberland, Westmoreland, Lancashire and a portion of Cheshire, and as a Celtish province it stretched at one time into Yorkshire as far as Leeds.

For Edward I's parliament of I275 writs were issued to thirty-seven counties, the three names omitted being those of Durham, Chester, and Monmouth-the last-named, as already noted, did not become shire ground till I535, and the other two were palatinates.

Durham was granted to St. Cuthbert and his successors in 685 , and was held by its bishops as a palatinate from the Norman Conquest until I836, when it was transferred to the crown. Chester, after the departure of the Romans was held by the Welsh till 607, when it fell under the power of Ethelfrith, king of Bernicia. In 828 Egbert annexed it to Mercia, and William the Conqueror made it a county palatine, and since I237 it has been an appanage of the eldest son of the king.

Thus, so far as it is possible to trace them, were the shires carved out of the Anglo-Saxon kingdoms. The term province has no obvious meaning in England beyond application to the ecclesiastical provinces of Canterbury and York. Mercia, Wessex, and Northumbria are sometimes mentioned as provincial divisions, and there is nowadays a tendency with some writers to revert to the old names of the Heptarchy. 


\section{V \\ THE BORDER COUNTIES}

Administrative areas disappeared from Scotland, as they had from England and Wales, at the termination of Roman rule in 4 ro.

It remained still to be settled whether the Angles of Northumbria and the Britons of Strathclyde should be annexed to Scotland or to England.

Both these states were largely under the influence of Edward the Elder, because he was able to protect them from the Danes, who were then ravishing the land on every side. In 945 Edmund Ironsides made the conquest of Cumbria, and then handed it over to the Scots king on military tenure. Cumberland remained in the hands of the king of Scotland till I237, when it was permanently annexed to the English crown.

When Edwin, the founder of Edinburgh, subdued all Northumbria in 942 , he divided it into baronies and counties, and transformed its kings into jarls or earls. One of the earldoms took the name of Northumberland, which extended from the Tees to the Forth, with the consequence that part of its history is interwoven with that of Scotland, till the death of Siward, who dethroned Macbeth of Scotland (I055).

The northern half, known as Lothian, of which Edinburgh was the chief town, was granted on certain conditions to Kenneth II, of Scotland, by Edgar the Pacific. Half-a-century later Lothian had become a part of Scotland absolutely (IOI8). 
In I0o6 Malcolm II. had made a great effort to annex Lothian, but he suffered a severe defeat on the banks of the Wear, while besieging a new town which was growing up around the shrine of St. Cuthbert, the missionary who had converted the Lothians-that town is now the city of Durham. Twelve years later he did succeed in a second attempt, defeating the Northumbrians at Carham on the Tweed. In the same year (IoI8) the latest independent king of Strathclyde died, and that district was also added to the kingdom of Scotland.

Even after his victory at Carham, Malcolm had to recognise the king of England as his overlord; and when Duncan, his successor, tried to throw off the yoke, he was disastrously defeated at another battle fought near Durham.

By 1068 there was a united England and a united Scotland, though the borderland between them long remained vague, undefined, and "debatable."

In that year Malcolm Canmore, always a troublesome vassal, made an attempt to annex Northumberland. William the Conqueror successfully resisted the attempt, and in I072 forced him to acknowledge his overlordship for Cumberland also. Twenty years later William Rufus seized Cumberland and placed an English garrison in Carlisle. It was during this struggle that a new castle (now Newcastle) was erected on the Tyne, to hold the district against the Scotch raiders.

The capital was removed from Dunfermline to Edinburgh by Edgar (I098) though homage was still being rendered to the king of England for Lothian and Strathclyde.

The Conqueror had given the county of Durham to one of his followers, Robert de Comines, as an 
earldom. The Norman garrison placed in the city was promptly massacred, and the English in York also rose on their new masters. The king marched against these northern insurgents and routed them with unsparing slaughter. A year or two later the Normans set fire to York before making a sally upon the English who were investing the city, and who with some Danish allies managed to defeat the attackers, inflicting heavy losses upon them. William was so exasperated, he collected an overwhelming force with which he again marched to the north, and laid it waste with fire and sword, driving the inhabitants to take refuge in the forests and mountains. From the Humber to the Tees, and from the Wear to the Tyne was made a desert. The history of the northern counties at this period was a tale of fury and carnage.

The country southward of Durham could scarcely have been sympathetic to Norman rule, and it is not at all surprising that Northumberland continued to link its fortunes with those of Scotland through the reigns of several succeeding kings of England.

In II57 Henry II. induced Malcolm to give up Northumberland, Durham, and Westmoreland, which had been held by Scotland since the disturbed days of King Stephen.

When William the Lion attempted to recover Northumberland, he was not only defeated, but compelled to acknowledge the king of England as his overlord for the whole of Scotland. Scottish independence, however, was shortly afterwards recovered from Richard I for a money fine. By the time of William the Lion, the counties of Northumberland and Cumberland had become English in their sympathies. 
Under the Normans Westmoreland was held in two baronies of two wards each for border service. It is significant of the demands of the locality that for 650 years the office of High Sheriff was hereditary in this county, the privilege being terminated only in 1849 .

The barons 'who opposed King John in the civil disturbances of that reign, secured the assistance of Alexander II. by promising him the northern counties of England, which he had always coveted. By the treaty of Newcastle, twenty years later, a compromise was agreed to that the Scots king, if he abandoned his claim to the whole of Northumberland and Cumberland, should be permitted to retain certain lands situated in those territories. The fact that Scotch kings and princes held lands in England on feudal tenure, tended not a little to complicate the relationships between the two countries.

It was not till I237 that the line of marches between England and Scotland became at all fairly defined, when an arrangement was come to that no further efforts should be made to extend the Scotch frontier southward. However, in May, I385, Scotland having made a league with France against England, a French force of two thousand men landed at Leith, and were afforded the pleasure of making a raid into England to lay waste the counties of Northumberland and Cumberland. And so the border game of harrying and plundering went merrily forward for yet another century or two.

Now to examine the state of affairs north of the border line. Berwickshire is the most southern portion of Lothian. Edward VI. and Mary, Queen of Scotland, by treaty made Berwick, which had been brought under the English crown 
in Edward IV's reign, a county town, and a free town independent of both states. Yet from this time until the death of Queen Elizabeth, Berwick continued to be involved in all the turbulence of constant border broiling. By 1603 , when the two countries were united under one crown, this town had changed masters no less than thirteen times in its chequered history. Though referred to separately in many national documents, Berwick is now considered an English town, situated politically in the county of Northumberland, though it cannot escape from Scotland geographically without crossing the Tweed. The uncertainty of its nationality in early times won Berwick-on-Tweed the distinction of being accounted a county in itself, and the singular honour of being specially mentioned in Acts of Parliament, after Wales, as a separate area in Great Britain. It may be claimed as the only English town whose members have sat in a Scottish parliament-this happened in the Bruce's time, and on one or two occasions subsequently.

The Saxons had entered the southern parts of Scotland before the close of the fifth century, and early in the sixth had established themselves in Lothian. Their attempt to dominate the country between the Forth and the Tay failed, but Lothian remained essentially Saxon, in speech and other ways. As we have seen, they were eventually separated from the Saxons of England, and absorbed into the kingdom of Scotland, the historic centre of which was at Scone, on the banks of the Tay.

It was, of course, to the Saxon element, that the introduction of the Shire system into the northern kingdom was due. But for a long time the policy of territorial divisions prevailed, 
divisions that were semi-independent and the frontiers of which could be clearly marked by some physical feature, as mountain, river or lake; to such divisions in Scotland proper may be traced many of the country's great historical names, like those of Fife, Angus, Athol, Argyle and Strathnairn. The Saxon policy of Shire divisions was quite unknown to the Celtic peoples, who long after the appointment of Sheriffs, treasured a hatred of them that was characteristically racial.

- The Galloway clans were always turbulent, and for centuries the kings of both countries failed in their efforts to maintian order among the Border freebooters, a Sheriff's posse often meeting with as sanguinary a reception as the marauders gave each other in their old-standing feuds and retaliations.

At first Galloway was rather a tributary than an incorporated part of the Scottish kingdom. The subjection of both Pictish Galloway and British Cumbria was for a long time uneasy and uncertain. But so far as the purpose of this work is concerned, the most important annexation was that of Lothian, because it meant that Scotland was not to be solely a Celtic country, but to contain a large English element. 


\section{VI}

\section{SCOTTISH SHIRES}

Mainly because neither state was strong enough to make the exact boundary line between the two countries a really effective frontier, the border countries remained in a disturbed and chaotic condition for centuries. As a matter of historic fact, the northern state was being all this time slowly but surely Anglicised in many of its institutions-certainly in those relating to its system of political divisions. To see how the English shire system was introduced into Scotland and developed there, it will be necessary to take a cursory view of Scottish history.

Sight must not be lost of the fact that for six hundred years before the Norman Conquest there had been an English population spreading itself and its racial influences over the south of Scotland. After the annexation of Lothian, the language and customs of Scotland gradually became more and more English, Gaelicism receding to the remoter districts of the north and west.

Scotland is made up of a number of confederate nations. Pictland to the north of the Forth, as far as the Spey, represents the land of the original Gaels. Galloway (Wigtonshire and Kirkcudbright) was occupied by a smaller but independent section of Picts. On the coast of Argyleshire was Dalriada, a settlement of Irish Scots, who in the end succeeded in converting the Picts to Christianity, and then in giving their name to the 


\section{SCOTTISH SHIRES}

whole country. At a later period, the temporary settlement of Norsemen in the great northern earldom of Caithness, was brought, under the Scotch kings.

The Gaelic population of Scotland contains three elements, the Picts, or northern Gaels, the Scots, or Irish Gaels, and the British or Gaels of Strathclyde. The Kingdom of Scotland had its beginning in 844, when Kenneth Mac Alpin, king of the Scots, united these Celtish peoples into what was called the kingdom of Alban, with Dunkeld in Perthshire for its capital.

Because of the hilly and inaccessible nature of the Highlands, the local chiefs of the northern Gaels acquired a power that, if not quite independent of any centralised authority, made them contemptuous of royal officials. There were seven separate districts under officials called Mormaers, each the head of a clan, exercising the authority of a petty kinglet. The Norwegian settlements and influence in the Orkneys and the Hebrides, in Caithness and Sutherland--the Norwegians were as troublesome to Scotland as the Danes had been to England-are almost outside the scope of this work, though it is interesting to note that in the eleventh century a Norwegian earl of Orkney held the office of Mormaer. Eventually, however, this Celtish title gave way to that of earl.

David I. (II24) was very much under English influence, and had a great deal to do with the earlier stages of Scotland's development of the English shire system. In his reign Scotland was divided into Sheriffwicks, in which the law was administered in the name and by the authority of the King; and the Sheriff was, both in theory and practice, the minister of the 
crown, for executing the king's writs as well as judging and trying cases, both civil and criminal - all precisely as it was in Norman England.

The Scottish Sheriffwicks were mostly settled in I305. For some time, Galloway, Argyle, and the western isles clung to their ancient policy and lay outside the system. When the Anglo-Norman policy at last prevailed, it was found expedient to make the Sheriffships hereditary in certain families. Under Robert I. (I306) and David II. (I329) an advance was made by granting Sheriffships for life.

Edward I., during the time he held Scotland, increased the number of Sheriffs in that country. To the policy of this monarch we are also largely indebted for the system of border warfare as a recognised institution-a lawless system which continued till the reign of James I., and during which (notwithstanding that the frontier had been irrevocably fixed) the sword was never long in the scabbard, and the border counties, if not exactly a waste, were shamefully kept back from peaceful development.

In the northern kingdom, as in England, the story of the Shires cannot be separated from the history of the evolution of parliamentary representation. From the twelfth century Scotland had its national assemblies of bishops, earls, and barons, which were held at various places, as Perth and Stirling. In the following century these great councils came to be called Parliaments, and began to include an element claimed as representative of " the community of Scotland"; at the parliament of I326, held at Cambuskenneth, certain " burgesses and other free tenants of the kingdom " were distinctly summoned to attend in a representative character. 
In I424, when James I. returned from his English imprisonment, full of English constitutional ideas, he proposed to relieve the small barons from the burden of attending parliament, provided they sent two or more "wise men" from each shire to represent them, except Clackmannan and Kinross, which were to send one each. An Act was passed to give effect to this, and thus, it will be seen, the English method of the representation of counties was closely imitated.

The Orkney and Shetland Islands, the most remote, if not the last shire-land added, were acquired by the marriage of James III. with Margaret of Denmark in I468; these now constitute an insular county. The name of the adjacent county, Sutherland, is no misnomer, though it is situated almost at the extreme north of the mainland; to the Norwegians who founded it "south land" was quite accurately descriptive of its relative position.

It will be found that one of the first things done by James III., when reducing the Highlands and the Isles to order, was to appoint Sheriffs to take charge of the several districts.

Cromwell was the first statesman who brought forward a well-considered scheme for the parliamentary representation of the three nations; in his second parliament (I654) England was to be represented by four hundred members, Scotland by thirty, and Ireland by thirty. He also fixed the proportion between the county and burgh representation of Scotland - the former were to have twenty members and the latter ten. For this purpose the smaller and less populous counties were to be grouped; Sutherland, Ross and Cromarty to return one member ; Forfar and Kincardine, one ; Fife and Kinross, one ; Linlithgow, 
Stirling, and Clackmannan, one; Dumbarton, Argyle and Bute, one; Ayr and Renfrew, one; Selkirk and Peebles, one ; Orkney, Shetland, and Cajthness, one; Elgin and Nairn, one.

It is interesting to note, in passing, that in the Scottish parliament, while the nobility and clergy occupied " benches," the commissioners of Shires and burghs sat on " furmes."

It should not be forgotten that even in the eighteenth century Scotland did not possess the right of popular representation as we understand it. The town councils elected the borough members of parliament, and in I790 the total number of voters in all the counties of the kingdom was only 2652. Other particulars concerning the Scottish counties may be found by consulting that voluminous work, Chalmers' "Caledonia:"

At the Union of I7I4 a return was made of the "Sheriffs and Stewarts" in Scotland, of which there were found to be 33 , given under three heads-9 held office " during pleasure," 4 held office for life (or lives), and 20 enjoyed hereditary office. In I748 the Imperial Parliament abolished all hereditary jurisdictions in Scotland which were associated with the ownership of land and titles of rank. 


\section{WELSH AND IRISH COUNTIES}

So far we have accounted for the origin and development of the forty English counties. The twelve counties of Wales came into the scheme of things at a later period of our history.

After his conquest of Wales, Edward I. sought to introduce the shire system into that country. In various parts of the conquered territory, government by princes had to give way to government by the king's officials. Instead of tiny principalities composed of commotes-in ancient Wales a commote was half a centred or hundred, containing fifty villages-grouped differently at different times, there were to be shires with fixed boundaries. Instead of ruling scions of the Welsh royal race, there were to be a sheriff, a coroner, and bailiffs of commotes in each shire.

Mona, being an island, was comparatively easy to make into a shire by itself, and it became the county of Anglesey. The wild district of Snowdonia, hitherto the unconquered heart of independent Wales, together with the adjacent promontory that runs out into the western sea, became Carnarvonshire.

The rest of Llewellyn's land became the shire of Merioneth, and these three counties were placed under the justice of Snowdon. The county court was held regularly in each of them every month ; and twice a year the sheriff was to make his tourn through the commotes, to inquire into all 
crimes and offences, after the traditional English manner. East of these territories lay the four centreds which had been in possession of King Edward before 1284, and which had risen in revolt because he had tried to introduce the shire system into them. The eastern portion was made into the shire of Flint, and the sheriff of Flint was to attend before the justice of Chester, and to bring his accounts to the exchequer of Chester.

South of Llewellyn's land, beyond the Dovey, were the territories of the royal house of South Wales, a picturesque land of feudal castles. From the castles of Cardigan and Carmarthen, Edward tried to establish his rule by introducing the English shire system there. These two southern shires were also given their sheriffs, their coroners, and their bailiffs of commotes, but were made subject to a separate justice-the justice of South Wales.

In re-organising the principality, Edward I. ordered the justices, sheriffs, and other officers, to administer, as far as was practicable, the ancient laws of Wales, which he had publicly recited before himself and his nobles at the Castle of Rhuddlan. "We have," he then proclaimed, " annulled some of them by the advice of our nobles, some we have allowed to remain and some others we have decreed shall be added." Edward I. was a statesman as well as a soldier.

After the Norman Conquest the English kings, in order more effectively to protect the borders, had given warrants to such of their barons as desired them to seize and enter upon the lands of Welsh princes. The land thus seized was called a "lordship marcher" and was held from the crown as a fief, but not subject to the usual con- 
ditions of feudal tenure. The Statute of Rhuddlan, which put an end to Welsh independence, did not apply to the territory of the Lords Marcher, and these districts remained as separate entities until 1536 .

From the date of the Statute of Rhuddlan the term "Wales" applied exclusively to the portion directly under the King's rule.

In I535 (27 Henry VIII.) an Act was passed " for laws and justice to be ministered in Wales, in like form as it is in this realm (England) "

By this Act the Marches or intermediate Border Lands between England and Wales, were divided into new counties, or annexed to old ones. The new counties were Monmouth (which became an English county) Brecon, Denbigh, Montgomery, and Radnor, in Wales; the English counties augmented by annexations were Gloucester, Hereford, and Salop; the Welsh counties augmented were Cardigan, Carmarthen, Glamorgan, Merioneth, and Pembroke.

The same Act directed the Chancellor of England to issue a commission to such persons as he should deem fit to inquire and view all the said shires of Carmarthen, Pembroke, Cardigan, Monmouth, Brecon, Radnor, Montgomery, Glamorgan, and Denbigh ; and thereupon " to divide each of them into so many Hundreds as should be thought most convenient, and to certify the said Hundreds to the High Court of Chancery ; which Hundreds (after such certificate) should be used and taken as other Hundreds were in every other shire within the realm of England."

By this Act Wales was removed from the jurisdiction of the Lords-Marcher, each of whom had been a kinglet in his own territory. The principality was also, with this legal constitution 
of its twelve counties, brought within the English parliamentary system. Eight years afterwards another Act was passed creating the courts of Great Sessions to which was assigned the work carried on by the Commissioners of Assize in England. These courts were held in each of the twelve counties, and they went on practically without alteration, down to I8zo.

Similarly, at a later period, James I. when modelling the Scotch local government upon the English shire system, appointed " Commissioners of the Middle Shires." After the Union of I603 there no "Borders"-they. had become the " Middle Shires."

Here a glance may be given at the English shire system as it has been introduced into the sister kingdom of Ireland. Henry II., after landing at Waterford in II7I, and establishing his authority in the south-east of the island, had not been in Ireland six months before he had divided the district ceded to him into counties, appointing sheriffs and setting up courts of law on the traditional English plan. King John continued the process with fresh annexations, and by his time there were three Palatinates in Ireland, namely Leinster, which had been granted to Strongbow, earl of Pembroke; Meath to De Lacy ; and Ulster to De Courcy. To these were subsequently added Ormond and Desmond; and Strongbow's Palatinate of Leinster was split up into five smaller palatinates.

The power of the Irish Lord Palatine was all but absolute. He had his Palatine Court, with its judges, sheriffs, coroners, and other usual officers, the territories being divided into counties. By I569 the whole of Ireland had been finally divided into shires. 
Presently as England was unable to protect her settlers in Ireland, they refused to call themselves English any longer, save only those in the "five obedient shires" which came to be known as the English Pale, outside which the king's writ no longer ran.

Two separate codes of law grew up, one for the English Ireland, which then included ten counties, though it afterwards shrank to four; the other for the rebellious English, which practically included the rest of Ireland. English law could not be enforced outside the Pale, and from time to time many ferocious Acts were passed, which tended not merely to separating the two classes of subjects, but to keep them from ever uniting.

By the reign of Mary the area of the shire lands was still limited, though increasing. Leix and a portion of Offaly, some of the more profitable lands of the centre, wereleased to English colonists, and called Queen's County, in compliment to the Queen; while an adjacent territory was named King's County, in compliment to Philip, her husband; at the same time Dangen became Philipstown, and Campa was re-named Maryborough. Other counties were formed in $I_{562}$.

Not till the time of James I. was every portion of Ireland made into shire land, when the last remnant of the native laws, as made by the Brehons or ancient law-givers of the land, was abolished. After the great U1ster Confiscation of 1607 seventeen new counties were formed.

In speaking of an Irish county, it is customary to omit the preposition; thus, while we say the " county of York," across the channel it is correct to speak "Co. Cork."

In Ireland the name Barony is given to a Petty Sessional Division. 


\section{VIII}

\section{COUNTY NOMENCLATURE}

In the majority of cases the name of an English county will give a clue as to its probable origin; whether it represents an ancient kingdom, or was a district occupied by settlers, or whether it was formed as an area of government around a burghal centre, and took its name from that centre.

As the Heptarchy faded out of existence, and a united England came into being, the original Saxon kingdoms declined to the position of Earldoms; in other words, they became, for all practical purposes counties.

Sussex, Essex, Wessex, and Middlesex were the kingdoms, as the names imply, of the southern, eastern, western and central Saxons. Wessex has disappeared from the list of counties. The south Saxons also founded Surrey, a name which appears in Robert of Gloucester's Chronicle in the form of Sothe-reye, that is, the south realm. Norfolk and Suffolk were the northern and southern divisions of the East-Anglian folk. Another shire name which reveals an ancient kingdom is Kent, though the name is one of British origin which the Jutish invaders just adopted; it signifies the territory of the Cantii, and is derived from a Celtic word for " corner " or " headland," which geographically Kent is.

The eighth and last of this group is Northumberland, though its area is but a poor shrunken remnant of the once extensive Anglian kingdom 
of Northumbria - the country north of the Humber.

Northumberland is a name, the origin of which may be attributed to its relative position-land north of the Humber ; or, if regarded as another form of Northumbria, as a piece of tribal nomenclature applied to the reduced area of a modern county, carved out' of that ancient kingdom.

The points of the compass, as might be expected from a hardy race whose " home was on the wave," entered largely into Saxon nomenclature; the cardinal points were never lost sight of as we see not merely in the county namesas South-Seaxe, North-folk, and so on-but in such place-names as Aston (East-town), Weston (West-town) Norton (North-town), and Sutton (South-town), of which they have left us scores of examples. The same method of structure is seen in the name of Northamptonshire or North Hants-the English county which touches the greatest number of other counties.

The second group of county-names also makes up a list of eight; they are those in which are preserved the names of ancient clans, or of some prevailing tribe.

The intermixture of the two races, where the conquering Teutons permitted the dispossessed Celts to remain among them, could not have been without important results on the language of the locality, and certainly on the place-names. In Wessex and in Mercia the bulk of the population was Celtic.

Even so late as the time of Henry II., Herefordshire was not entirely Anglicized, and it was not till the reign of Henry VIII. that Monmouthshire was first numbered among the English counties. The nomenclature of these two counties, however, was not affected by this fact. 
In the name Cornwall, which is equivalent to Cornwales, "the kingdom of the Welsh of the Horn," is recorded the fact that the Britons were driven into this peninsula as they were into Wales, and given the same nickname, "Foreigners," by their overbearing conquerors. Another body of Britons found security in the hills of Cumberland, otherwise " the land of the Cymri," the real name of the Welsh. By some authorities the name of Cornwall has been derived from the Cornavii tribe.

In Devon survives the name of the Celtic tribe, the Damnonii (a word which has been claimed to be of Phœenician origin, made up of Dan or Dun, " a hill," and moina, " mines"). The Cornish called this county Dunan, but under Saxon rule it became Devenascyre or Devonshire.

According to English mythology, the name Devonshire is a corruption of Debon's share. This Debon was one of the heroes who came with Brutus from Troy. One of the giants that he slew in the South coasts of England was Coulin, whom he chased to a vast pit, eight leagues across. The monster trying to leap this pit, fell backwards, and lost his life in the chasm. When Brutus allotted out the island, this portion became Debon's share. Thus in Spenser's Faery Queen (ii. IO).

And eke that ample pit, yet far renowned

For the great leap which Debon did compell

Coulin to make, being eight lugs of ground

Into the which retourning back he fell .

In mede of these great conquests by them got

Corineus had that province utmost west

And Debon's share was that is Devonshire.

Although Wessex disappeared from the map, its divisions retain good Teutonic names. In the names Dorset and Somerset, the terminal " set" or seat, signifies the habitation of settlers. In 
the word Wiltshire again, the $t$ belongs to this root; in the Saxon Chronicle the men of the county are called Wilsætan, just as the men of Dorset and Somerset are called Dornsætan and Somersætan; it was the seat or " settlement of the Wyltic tribe," a people found in Germany in the sixth century.

Somerset may possibly have been named from the Saxon Sumerton, because of the summerlike temperature of the locality-the Welsh for the same reason called it Glad-arhaf. Dorset is believed to reveal the name of the Durotriges, or "dwellers by the water."

In the will of Alfred the Great, Dorset, Somerset, Wilts, and Devon are enumerated as "Wealhcynne," a phrase which proves that these counties were then Celtic in blood and language, although politically they belonged to the Anglo-Saxon Commonwealth. Wiltshire may possibly be Wilton-shire, Wilton being a contraction of Wily-town, a town inhabited by a mixed race, on the river Wiley.

Worcester, the British name for which was Wigorn, was the country of the Hwiccas. In Anglo-Saxon charters the name appears as Wegerna-cester, Weogern, Wihgeraceastre, and a variety of forms up to the tenth century, when the addition of " scire" is made to the name of the county ; in one instance the town is specified as " in metropoli Huicciorum." The country of the Hwiccas extended from the lower Severn halfway into Warwickshire.

In the name of Nottingham we have a relic of an old English tribe of troglodytes, of whom very few other traces remain. The word Nottingham disguises the original form Snot-incga-ham, the ham or home of "the children of the caves." 
An old British name for Nottingham was Tyogofawr, "the house of the cave-dwellers." The sand-rocks on which this town is built are easily perforated, and rock houses existed there in the last century. Mortimer's Hole, under Nottingham Castle is a cave well known to history.

According to the thirteenth century scribe, Roger of Wendover, Nottingham was called in the tongue of the Britons, Tinguobanc, which meant the " house of dens," or of caves.

The names of the great bulk of the English shires, as might be expected from the way these divisions were formed, were borrowed from the county-towns, from the burghal centres around which they grew up as administrative areas. In these cases, which constitute our third group, where the shire name is obtained from that of the dominating town within its borders, it will be necessary to get at the meaning and derivation of the names of the respective towns.

Alfred the Great and his successors had built a number of " burhs," which it was the duty of the neighbouring free-holders to garrison and maintain. These strongholds, though sometimes called castles, were really stockaded mounds; it was with their aid that an end had at last been put to the Danish forays; and these places became the centres for the new divisions or administrative shires in the Midlands.

Those so named had, as a rule, a different historical foundation from the counties with tribal names, such as Devon, Essex, or Kent. With hardly an exception names of the former class belong to the Mercian or Northumbrian kingdoms, which were conquests or annexations posterior to the date of the Saxon immigration. Successive districts, as they were annexed, took 



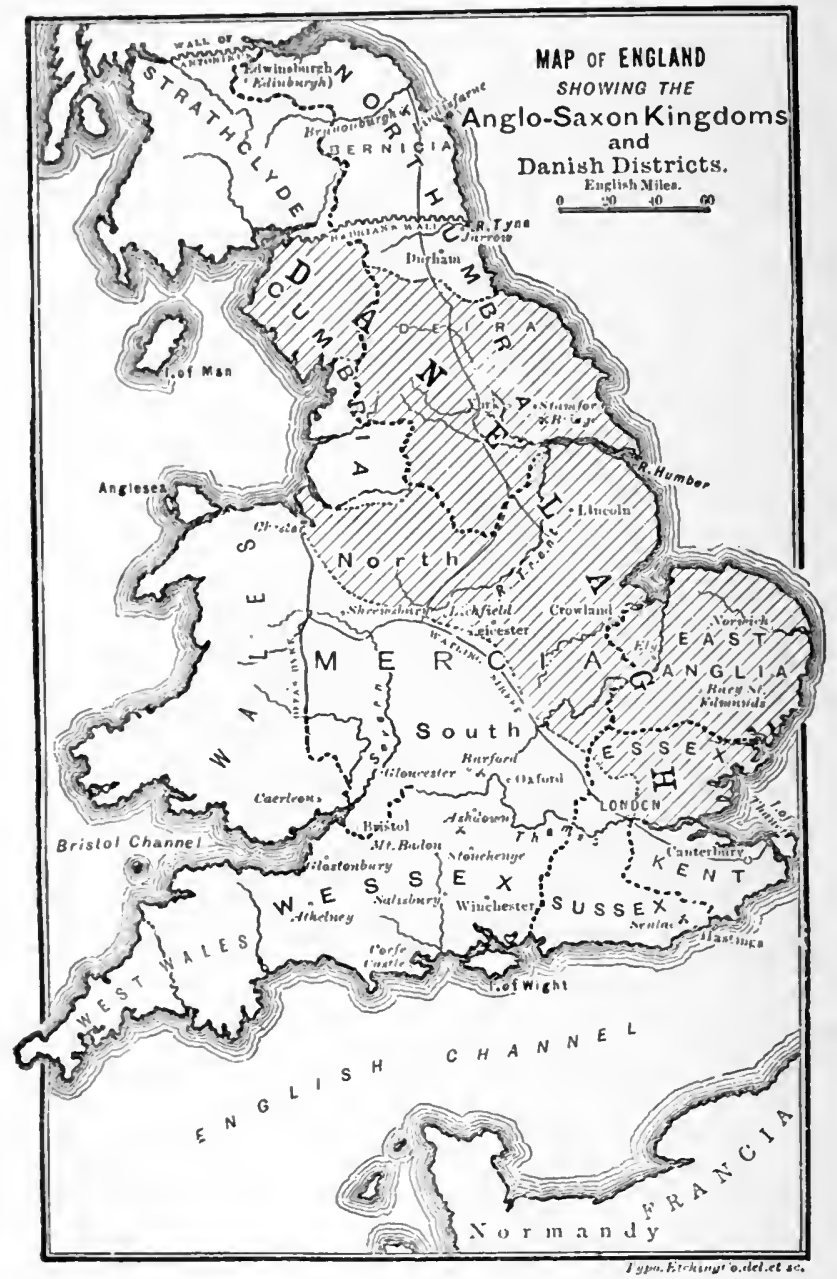


their names from the town in which the earl held his court, and from which he governed his conquered earldom. Names of the one class, like Sussex, point to the original tribal kingdoms; those of the other, like Derbyshire, mark the boundaries of the subject provinces.

Derby was at the first called Northworthig by the Saxons; this was before the fortune of war had created the Danelagh, or Danish kingdom, where the Norsemen were predominant. According to one theory the Danes, when they became paramount, rejected this name and called the place Derby, from deor "a wild beast" and by, "an abode," because it was " the village of wild beasts," in a clearing of the great midland forest between Sherwood and Arden. Another opinion derives Derby from Derwentby, the village on the river Derwent. The Earls of Derby take their title, not from the Co. Derby, but from West Derby in Lancashire, which is always pronounced as if spelt with a.

Some etymologist derives Durham, like Derby, and makes it signify the " home of wild beasts." This origin is more than doubtful, as in the Saxon Chronicle the name is written Dunholm, which at least gives it the Danish suffix holm (an island or a grassy hill by the water) and not the Saxon ham (home). The bishop's signature is Dunelm, which again changes the prefix from the Danish Deor ("wild beast") to the British Dun, “ a hill."

The bishops have been used to sign in Latin and in French alternately, as each succeeded to the see; thus if the last bishop signed Dunelm, the living incumbent of the see would sign Dunesm, the next again Dunelm; and so on. 
A goodly number of the towns which designated the counties they dominated, have names associating them with the waters on which they stood. Gloucester is " the fortress near the clear water," derived from the British word gloyw, " clear." The Britons called Gloucester Cær Gloyw, " the fortress near the glowing or clear water," which the Romans Latinised into Glou or Glevum. The Saxons restored the old British name Glou, adding to it ceaster, to signify it had been a Roman camp.

Monmouth is at the mouth of the river Monnow, where it makes its junction with the Wye; and the Monnow water was, in the British tongue, the Mynydd, or " mountain river." This county with Glamorgan made the British Kingdom Gwent, a name meaning an open elevated county, Latinised into Venta by the Romans, and sometimes called Wentsel or Wentsland.

The name of Lincolnshire is obtained from its chief town Lincoln, which was a British fortress on the river Lindis, now the Witham. The Romans in succession made the place one of their chief stations, established a colony there, and called it Lindum Colonia, from which it is easy to trace the contracted form of Lincoln-which is substantially a Latin name for an English town. The Lindum is a corruption of the old British Ilyn-dune, or " fen-town." In Early English times the county was sometimes known as Southumberland.

Another river-named town is Leicester, the cester or " camp on the Leir " or Ligera, now called the Soar. (Some authorities, however, derive Leicester from Legionis Castra, precisely as they do Chester from Castra Legionis, each place having been the permanent station of a Roman legion.) 
York is a contraction of Eure-wic (pronounced Yor-ric) the Eure being now called the Ouse. The Romans called the place Eboracum, and the Archbishop signs himself Ebor.

Obviously Lancaster is the " castra on the I une," or the Lon as its older pronunciation was. Popular tradition, as unreliable as it is fanciful, has derived Lancaster from Lang Kester, that is Long Christopher, who in far away times used to carry travellers over the river Lune at this spot.

Cheshire, made up from Chester, is Castra-shire. Chester was called by the Romans Devana castra (the camp town of Deva, or Dee-mouth). But it was pre-eminently the great Roman city, the Castra-that it had been a British settlement, the chief stronghold of the Ordorvices, was quite ignored-the Latin Chester, without any Celtic prefix.

Among the Saxons there were few towns worthy the name; markets and fairs were often held at fords or bridges, where road and river met, and hence it is that many towns which eventually grew up at these points bear the word ford or the word bridge as part of their names.

Several in the same category were fording places, whose importance arose from the traffic brought to them as well-frequented places. Oxford is a good example. In Ceadwalla's grant to the abbey of Abingdon, made in Saxon times, mention is made of " eoccenforda," which is believed to be the earliest form of Oxford, the name of which long remained in the form Oxenford, literally " the ford for oxen."

Hertford in its pronunciation, if not in its spelling, is plainly " the hart's ford," although an origin has been claimed for it in Harting'sford. Taylor traces it through the Celtic rhyd, a ford, as a reduplication of terms. 
Stafford is popularly derived from " the staffford," the town at which the shallow Sowe could be crossed by the aid of a staff. The old form, however, was Stæthford - the ford nearby a landing place; staithe being an old English name for a riverside landing.

Some antiquarians explain the name Hereford as a Saxon word meaning " army-ford," forgetting that the Saxons called the place Feren-lege, that is " the meadow of fern." One of its British names was Henffordd, that is " the old way." Probably the true etymology is from its other British name Cær-ffawydd, corrupted by the Saxons to Harford and then to Hereford. This etymology is supported by Shakespeare's accenting the word as two syllables in the line-

Harry of Hereford, Lancaster, and Derby.

Some old writers spell the name Hariford.

The etymology of the name Bedford has given rise to much controversy. The first syllable Bed occurs in a number of place-names, but in this case it has been very variously interpreted. On Saxon coins minted in the place the town's name appears in the form Bedafor, and in the contraction Bedaf and Beda. Anciently the name was frequently written as Bedanford, which has been taken as an abbreviation of Bedicanford, meaning the " fortress by the ford." Another contention is that the name is derived from the Cymric Bedw, " a birch grove," because it was the "ford in the birch woods" ; and yet another that its signification is " the beggars' ford," derived from Bedica, a beggar. Many incline to regard the first syllable as the relic of a personal name, Beda or Bedca, and a few have even claimed the word Bedford as equivalent to Bideford, otherwise By-the-ford. 
Cambridge appears in the Anglo-Saxon Chronicle, under date 875 , as Grantanbryce, " the bridge over the Granta" ; it also appears at an early date as Granta-ceaster, or Grantchester. It is therefore evident that the town practically occupied the site of the Roman station, Granta. Spenser and Drayton call the river on which it stands, the Grant. But Chaucer calls the town Cante brigge ; and the river has for centuries been known as the Cam. It is difficult to believe that Cam is a corruption of Granta. Whatever the river was called, it is more than probable it was crossed by a ford long before it was spanned by a bridge, and that Cambridge, like Oxford, derived its earliest importance from a water-crossing. The Rev. Isaac Taylor says that in "Camboritum," the ancient name of Cambridge, the syllable rit represents the Celtic root rhyd, " a ford."

At Camboritum two great Roman roads intersected, one of which, the V1a Devana, was made to pass sheer through the river by the construction of a paved causeway, laid on the bed of the sluggish stream. For some reason best known to themselves the Roman engineers did not throw a bridge across the Granta, or the Cam, whichever they called it; and the fact which emerges is that for centuries the place was known as a "ford of the Cam," but by Chaucer's time had changed its name to Cam-bridge. The primeval fortress of the Britons, covering some sixty acres, and defended by mighty earthworks, a formidable stronghold which the Roman conquerors appropriated, stood on the left bank of the river.

Warwick, which gives its name to Warwickshire, was at first the Weringwic, the fortressvillage, or station of soldiers. 
Huntingdon is not improbably the Hunters' hill; the terminal don signified a hill-fortress. These last two names indicate an origin through conquest and annexation at a date posterior to the Saxon tribal immigration.

Hampshire is a contraction of Hamptonshire, named from the county-town Hampton, standing on the river Anton, and now called Southampton, to distinguish it from Northampton. The Shire is also called the County of Southampton. The natives prefer not to derive the name from the river, but from the fine old Saxon word ham, making it the homestead of the original Teutonic settlers. Ham, like the German heim, signifies, at first, an inclosure, that which hems in ; and in essence expresses the sanctity of the family bond, of the home, among our Anglo-Saxon progenitors.

The Isle of Wight, which forms part of the county was called, according to the Anglo Saxon Chronicle, after the name of Wihtgar, great-grandson of King Cedric, who conquered the island.

Northampton in the Saxon Chronicle, A.D. 9I7, is Hantun, and in Domesday Book, North Antone. In 1087 it becomes North-hamtun. Shropshire and Salop are names derived, directly or indirectly, from Shrewsbury. In Domesday Book (I086) the town appears as Sciropesberie; and the county as Sciropescire; in the Pipe Rolls (II59) Salope and Saloscir appear for the first time. In the Anglo Saxon Chronicle, under the year 1006, the town's name is written Scropesbyri, and the county's Scrobbesbyrigscire ; in which the Scrope or Scrobbe is probably a personal name, though Shrewsbury has sometimes been interpreted as Shrub-borough. As to pronunciation the sc in the first syllable was originally sounded as sk, but later became sh, and 
eventually just s. Then Srop, or Scrob, not being easy to say (though to this day, the vulgar pronunciation of the name in the immediate locality makes it S'ropshire), the name in process of time developed into Slob, Slop, and ultimately into Salop. The word Salop is generally accepted as derived from the Norman " Sloppesburie," a corruption of the Saxon Scrobbes-burh (Shrub borough) the original of Shrewsbury.

Another group of county names is constituted of those which are derived from some physical characteristic, or some dominant natural feature of the locality. Thus Rutland, or Roteland, obtains its name from the English word rot, "red," and is so called on account of its red soil.

It is curious to notice how our Teutonic ancestors seemed to seize upon any natural feature that differed from or reminded them of their native land. Denmark, the home of the Jutes, was an undulating land of low hills and spreading moorland, consisting mostly on the surface of meadows and beechwoods. Of its forests more than fifty per cent. were beech trees. So among our county names we have Buckinghamshire taking its name from the county town, which was the "ham in the becen," or the village among the familiar beech-trees.

No county bears a name of greater historic value than Berkshire which was named from the tree under which its shire-mote was held in the very earliest times. According to Asser, the biographer of Alfred the Great, than whom no authority could be more weighty, the name is derived from Bar oc (bare oak) otherwise a polled oak in the forest of " Wyndesore," under which the people were accustomed to assemble for the transaction of the public business of the shire. 
Speed, the sixteenth century antiquary, remarks - Bark-shire whether of the Box-woods there sited, according to the censure of Asserius Menevensis, or from a naked and beare-lesse Oke-tree, whereunto the people usually resorted in troublesome times, to conferre for the State, I determine not."

Of the last county to be treated here, the Saxon name seems to have been West-moring-land, the west land of the moors." Geoffrey of Monmouth (II54) gives currency to a legend that Mar, son of Arviragus, one of the descendants of Brutus, the Trojan Wanderer, killed Rodric, a Pict, and set up a monument of his victory in a place which he called West-mar-land:; and the chronicler adds that "the inscription of this stone remains to this day." The second syllable has also been given as mere making the county to be West-mere-land.

This completes the name-derivations of the forty English counties. Although the Welsh counties were not all named till a much later period, it will be convenient to deal with their nomenclature here.

In North Wales four of the six counties are named after their chief towns, namely Carnarvonshire, Flintshire, Denbighshire and Montgomeryshire. Anglesey obtained its name from its Teutonic invaders, and Merioneth has retained its ancient British name.

In South Wales five of the six counties have names that correspond with those of the chief towns; namely Cardiganshire, Pembrokeshire, Carmarthenshire, Brecknockshire, and Radnorshire (New Radnor a town of 3,000 inhabitants, is not now the county-town of the last-named, but Presteign, a mere village) while Glamorganshire 
has a Celtic name, the real origin of which has been lost in the mists of antiquity.

Anglesey is generally supposed to be, literally interpreted, "the Englishman's island"; the Rev. Isaac Taylor makes it " Onguls eg," meaning "the isle of the strait." By the Ancient Britons the island seems to have been called Mon, signifying remote; this the Romans Latinised into Mona, "the nurse of Wales," because of its fruitfulness.

Carnarvon is Cær-yn-Arfon, the city of Arfon ; Arfon being the land over against Mona's isle. In Gray's ode " The Bard," we have the reference

On dreary Arvon's shore they lie.

Flint is not so called because it is the county of siliceous rocks. Old documents make allusion to Castellum apud Fluentum, "the castle on the flow," or tideway. The word Fluentum, applied to the adjacent town on the Dee estuary, has in course of time been corrupted into Flynt or Flint.

Denbigh-like the Flemishly corrupted form, Tenby-is a Welsh word signifying " cliff."

Montgomery till I533 was a part of Powysland. The castle there was captured from the Welsh by Roger de Montgomeri, a Norman noble who gave his own name to it. The name of the castle, as in the case of Flint, passed on to the town which grew up round its walls; and when Henry VIII. made it the county-town, it was allowed to name the shire in which it stood-a unique example of a Norman name so applied. The Welsh call it Baldwinshire (Sir Dre Valdwyn) after the original holder of the castle.

Radnorshire was named by Henry VIII. from New Radnor, which he made the capital of the county. Probably the literal signification of Radnor is " red shore." 
Pembroke is Pen-bro, signifying the " head of the land "-a name highly descriptive of its physical features.

Cardigan is a corruption of the old name Keredigion, the country of Keridig, a son of Cunedda, a sixth century Welsh prince.

Merioneth is also said to be derived from a personal name-that of Meirion, a Welsh saint, and another son of Cunedda. A second derivation, however, has been proffered-" mæronæth," a dairy farm.

Another Welsh legend asserts that Brecon was named after Brycnan, the eponymic king whose daughter was martyred by the heathen Saxons and Picts at Merthyr Tydfil.

Carmarthen is believed to be Maridunum, the sea fortress, which with the prefix Cær signifying the city, became Cær-marthen.

An old British legend chronicled by Geoffrey of Monmouth gives a romantic, though highly improbable origin for the name of Glamorgan. $\mathrm{He}$ says that Cundah and Morgan, the sons of Gonorill and Regan, usurped the crown at the death of Cordeilla. The former resolved to reign alone, chased Morgan into Wales, and slew him at the foot of a hill, a place ever afterwards called Gla-morgan, or Glyn-morgan, otherwise the valley of Morgan. A more probable derivation is from mor the sea, and gant side, and makes the name Glamorgan express " the place by the sea-side" -and synonymous with the Celtic Armorica.

The Cornish and Welsh languages, it may be noted here, were originally indentical ; they were 'two branches of the Cymric, as the Armoric of Brittany is another.

In remote parts of Devon the ancient Cymric speech feebly lingered on till Tudor times, and in 
Cornwall was still the general medium of intercourse. On the other hand in the Welsh border counties of Glamorgan, Flint, Denbigh, and Montgomery, the English language has encroached very largely upon, and in many parts has displaced, the native language.

While the natural features of the country were allowed to retain their British names-every river-name in the island, for instance, is of Celtic origin-the towns, strongholds, and political divisions had Teutonic names conferred upon them by the dominant race. Exceptions to this rule may be found in the border counties of Salop, Hereford, Gloucester and Devon, and in the mountain fastnesses of Derbyshire and Cumberland, where occasionally village names occur with the prefixes lan and tre interspersed among the Saxon patronymics.

And yet most of the shire names contain Celtic roots. The Rev. Isaac Taylor gives the following list of such-Cambridge, Cornwall, Cumberland, Dorset, Durham, Gloucester, Hertford, Huntingdon, Kent, Lincoln, Lancaster, Monmouth, Northumberland, Oxford, Worcester, and York, together with all the Welsh and Scotch counties except Anglesey, Montgomery, Haddington, Kircudbright, Selkirk, Stirling, Sutherland, and Wigton. There are a few of the chief ancient centres of population which bear Celtic names, as London, Winchester, Gloucester, Exeter, Lincoln, York, Lancaster and Carlisle; while some of those which originated from isolated family settlements in the uncleared woods are distinguished by Teutonic names, as Buckingham and Derby.

Anglesey in Wales, and twelve counties in England-Cornwall, Cumberland, Durham, Essex, Kent, Middlesex, Norfolk, Northumberland, Suf- 
folk, Surrey, Sussex, and Westmoreland-bear names which do not terminate in " shire."

In three cases the terminal " land" would perhaps make the addition of shire redundant, although the objection has not applied equally in the case of Rutlandshire. As explained elsewhere Durham was originally an ecclesiastical diocese, and not an earldom or civil shire.

For obvious reasons the termination "shire" has never been appended to the Celtic state of Cornwall. Nor has it been attached to Essex, Sussex, Middlesex, Surrey, Kent, Norfolk, and Suffolk, because anciently they were autonomous kingdoms, and not portions "shorn" away from other states. The same distinction has been claimed, though not for the same reason, or a particularly valid one, for Somerset and Devon.

Most of the English counties have by-names or convenient abbreviations of their full legal designations. Many of these terminate in s, which may be taken as signifying shire; as Beds, Berks, Bucks, Staffs, Lancs, Lincs, Yorks, Notts, Wilts, Hunts, and Herts. In some cases the termination of shire is dropped without the addition of the s; as in Warwick and Derby.

Other counties are fortunate in finding short names easily understandable; as Devon, Oxon, Salop, Rutland, Hants. Others again seem impossible of curtailment as Durham, Hereford and Kent.

The best authorities spell the name Gloucester in full; Shakespeare and the Post Office cut it down to Gloster, which is tolerable and to be endured; but the compromise between these two forms, sometimes accepted as good journalese Glocester, is without justification. 
The pronunciation of Derby-whether the er be sounded like ar, as in clerk, person, Berkeley -must remain a matter of taste. The same option is scarcely allowed us in the names Hertfordshire and Berkshire, which are invariably pronounced Harfordshire and Barkshire. In the seventeenth century Derby was most frequently written as Darby, and the territorial title of nobility is always so pronounced. The departure from the usual sound of $e$ in these words may be attributed to an alteration in the sound values of the vowels, and partly perhaps to original derivations. 


\section{IX}

\section{THE SHIRES AS EARLDOMS}

Each Saxon shire had a separate organisation, and the entire system of shires made up the kingdom. Its chief was called Ealdorman or Heretoga, according as he was engaged in peace or war.

A Shire might be defined as containing a circuit or proportion of the realm into which the whole land is divided for the better goverment of it, and the more easy administration of justice; so that there is no part of the kingdom that lies not within some county.

Every county was also placed under the supervision of a yearly officer called the Shire-reeve, who represented the king ; and of whose office more detail presently.

Before the subdivision of the entire country into shires, the old subject kingdoms were sometimes constituted earldoms. But the earls sought to make their office hereditary, and were powerful enough to give the king much trouble. During the Danish period, while the office of the Elderman in the shires became less important that of the earl (the Danish " jarl" is equivalent to the Saxon " eorl ") which became exalted, even at the expense of the royal authority. Siward, " the right valiant," earl of Northumbria, the famous Leofric, earl of Mercia, and the rebellious Godwin, earl of Wessex, made themselves semi-independent. Of the latter's two sons, Tostig became earl of Northumbria, and Harold actually acquired the crown of England. 
The Norman Conqueror discreetly limited the powers of his barons and earls, except in two cases ; the Bishop of Durham, who had to keep order on the Scotch borders, and the Earl of Chester, who had a similar responsibility on the Welsh Marches.

The Ealdorman or Elderman (practically the same word as Alderman) was not a territorial noble, but an appointed officer, who held a meeting of all the people of the shire twice a year, to settle disputes, punish offenders, and collect fines. His social status was different from that of an earl, though his functions may have been practically the same.

In dealing with these officials there was at times considerable trouble; some of them being found dishonest, and not a few of them ambitious. Ethelred made an ineffective attempt to restrict the powers of the Eldermen.

William of Malmesbury accounts for thirty-two counties existing in the reign of Ethelred, and Robert of Gloucester for thirty-five, including "Winchelcomb," since joined to Gloucestershire. No mention is made in these lists of Cornwall, Cumberland (styled also Carlisle-shire) Northumberland, Lancaster, Westmoreland, Durham, Monmouthshire, and Rutland. Cornwall, says a Tudor writer who quotes these old chroniclers, remained British till William the Conqueror gave it to his brother, Robert of Moreton; Cumberland, Northumberland, "Westmerland," and Durham were ranged, in the Saxon period, either under Scottish or under Danish rule; Lancashire was no county until Henry III. made it so, nor had Rutland any Earl till the time of Richard II. This is not strictly correct, but the list of the thirty-two earliest counties is interesting from their classification which is given thus- The 
nine counties under West Saxon law were Kent, Sussex, Surrey, " Hantshire," Berkshire, Wiltsshire, Somerset, Dorset, and Devonshire ; another eight were under Mercian law, namely Oxford, Warwick, Hereford, Gloucester, Shropshire, Stafford, Worcester, and Cheshire ; and the other fifteen were in Ethelred's reign under Danish law; namely Essex, Middlesex, Suffolk, Norfolk, Hertford, Cambridge, Bedford, Buckingham, Huntingdon, " Northamton," Leicester, Derby, Nottingham, Lincoln, and Yorkshire.

It is not probable that there existed, side by side, in every shire area, both a territorial (and sometimes hereditary) ruler, known either as " earl" or " jarl" (or in later times by the Frankish equivalent, "Count"), and the king's appointed highest representative, the "Ealdorman." But from an early period there came into existence an official who was the real and actual executive of royal authority, one to whom the practical government of the shire was entrusted, either as the Earl's deputy or the Ealdorman's subordinate. $\mathrm{He}$ was known as the Sheriff, or Shire-reeve. In English, the name implies simply and directly what he wasthe Officer of the Shire : but the Latin equivalent still in legal use " Vice-Comes," shows his original position as subordinate to that of the Count, or Earl. In process of time, however, it was upon the Sheriff or Vice-Comes that the civil administration of the county totally devolved-he superseded both earl and ealdorman, and the Shire Moot or County Assembly became the Sheriff's Court.

The Ealdormen, says an ancient authority, at first enjoyed " the title of Earles, in whose disposition was the government, upon delegation 
from the king, the title being officiary and not hereditary, except in some particular shire."

According to one learned authority, when, in process of time, the Ealdormen merged into Earls, the latter, by reason of their high employment, military duties, and attendance upon the king's person, not being able to transact the business of the county, the burden of it was delivered entirely into the hands of the Sheriffs.

After the Conquest only four Ealdormen were to be found in the whole of England, the administration of several shires being in the hands of each of these. By this time the Saxon idea of kinship as the basis of society had so weakened that the call was urgent for a king's executive officer in each shire. It was under these circumstances that the Sheriff rose to be the king's right hand in the county area.

According to Lord Littleton, in his History of Henry II., lib 2 fol. 2 I7, each county was anciently an earldom, so that previous to the reign of King Stephen, there were not any titular earls, nor more earls than counties, though there might be fewer.

The double nomenclature of county and shire reflects the social and political conditions under which the terms originated. Shive is a word connected by Trench with " share " and " shear" and is properly a piece of land sheared off.

When a Saxon king created an earl, it did not occur to men's thoughts, accustomed as they were to deal with realities, that such should be merely a titular creation, or exist without territorial jurisdiction; and a share or shire was assigned to him to govern, which also gave him his title. 
At the Conquest this Saxon officer was displaced by a Norman, the earl by the count (comes meaning originally " companion "- one who had the honour of close companionship to the leader, or king) : it was then the shire became the county (comitatus) or the territory governed by the count.

Strangely enough the title count has disappeared from the titles of English nobility, and the earl has recovered its place and is the most ancient of our titles of nobility; notwithstanding which, the wife of the earl is called a countess. Territorially the two names " shire " and "county" still survive, side by side.

Many Spanish counts bear the devices of a cauldron in their arms which is taken to signify their greatness in housekeeping and ability in maintaining those whom they lead. FolkLorists have thought the famous porridge pot of Guy, Earl (comes) of Warwick, may have had some connection with this association.

Whilst the original Saxon shires were generally earldoms, no territorial significance is now attached to a title of nobility appropriating a county-name.

Quite recently Lord Carrington, on being raised a step in the peerage, took the title Earl of Lincolnshire, although the family seat is situated in Bucks.

A more glaring example is that of the Duke of Devonshire, who is a great territorial magnate in several counties, particularly in Derbyshire, yet owns no estates in the county from which his title is derived. Tradition explains this by the story that when the first patent of nobility was made out for the head of the Cavendishes in the reign of James I., the Clerk made the mistake of writing Devonshire for Derbyshire, and that the error 
was allowed to go unrectified. It must be borne in mind that the first Cavendish dignity was an Earldom, and there was already in existence an earldom of Devon, in the Courtney family. By the way, it is contended by some precisions that the county should be called Devon, and not Devonshire.

Cornwall, as previously noted, is a royal duchy belonging to the Prince of Wales; there are other county-names which have been strictly reserved for use by princes of the royal blood as titular dukedoms; as Cumberland and Kent. There are in existence also dukedoms of Somerset, Rutland, Northumberland, and Norfolk. The lastnamed also carries the second title, Earl of Surrey.

The earl of Wiltshire is borne as the second title of the Marquis of Winchester, while one nobleman appropriates two county-names-the Earl of Suffolk and Earl of Berkshire. Among the other counties which now name titular earldoms are Buckinghamshire, Essex, Huntingdon, and Westmorland. There are other county names in use as titles, some borne as secondary titles.

Obviously, from the foregoing, a new peer in choosing a title could not be permitted, if below the rank of Earl ("Count") to adopt the name of a county or a county town.

Three grades of earls are described and defined in Burke's Peerage, of whom the Earl Palatine is highest.

The style of an Earl is " Right Honourable," and he is officially addressed by the Crown as "Our trusty and right well-beloved Cousin," a mode of address invented and artfully used by Henry IV., that prince having been either by his wife, his mother, or his sisters actually related or allied to every earl in the kingdom. 


\section{$\mathrm{X}$ \\ COUNTY ORGANISATION}

Having seen how the shires were formed and named, the next point to claim the attention, is their organisation for gubernatorial purposes.

When communication between distant parts of the country was difficult, the problem of government from a central authority was not so easy to solve. In Tudor times, for example, under a highly organised Privy Council Government, it was found necessary (after the uprising of I536, known as the Pilgrimage of Grace,) to strengthen the king's authority in two outlying parts of the realm by setting up divisional Councils, one for Wales and the Marches (see p.7I) and the other for the Five Northern Counties. The Northern Council was abolished by the Long Parliament, as was also the Court of Star Chamber.

It seems probable that when the realm was originally divided into counties, it was done primarily with a view to the convenient administration of justice ; for the judicial business of the kingdom was in early times chiefly dispatched in local courts, held in each different county, before the duly appointed officers of the crown.

Nor must the influence of the church in local government be overlooked. After their conversion to Christianity the influence of the clergy among the Saxons became very great, the humblest priest ranking with the landed gentry as a " mass 
thane." Originally the bishops' dioceses were ecclesiastical divisions co-extensive with the kingdoms of the heptarchy, and therefore with the ancient kingdoms which became shires. Each djocese (or shire) beyond its civil divisions was ecclesiastically divided into parishes, co-extensive with the Saxon township; that is, into preost scyres, each being the district of a single priest. The Bishops became members of the Witana Gemote or national Council, though in time they retired from participation in the work of the County Courts.

Hume says that it was Alfred the Great who, " that he might render the execution of justice strict and regular, divided all England into Counties; those Counties he subdivided into Hundreds; and the Hundreds into Tithings". The statement appears to be made on the authority of Ingulphus-secretary to William the Conqueror-who asserts that " Alfred divided the kingdom into counties, hundreds and tithings." William of Malmesbury repeats the statement, and gives a reason for the measure; namely, that it was to ensure safety of intercourse among the people that Alfred " appointed centuries which they call hundreds, and decennaries, that is to say tithings; so that every Englishman living according to the law must be a member of both."

In Saxon times the Court of the township was the Hallmote or Halimote; but a little later this developed into the Court Baron, the Court Leet, or the Customary Court of the Manor having civil jurisdiction. It was a court of freeholders in which the steward of the manor acted as judicial officer. Every manor had a Court Baron, but a Court Leet was a franchise granted by the crown 
conferring the criminal jurisdiction anciently exercised in the Hallmote-now superseded by courts of summary jurisdiction.

The constitution of the Hundred is found to be so anomalous that really it is difficult to divine on what principle it was founded. Some of the smallest Shires present the greatest number of Hundreds, but this may have arisen from their being more densely populated.

That a Hundred consisted of a hundred families of freemen is, after all, a mere guess. In the time of Edward the Confessor, the Hundreds of Northamptonshire seem to have consisted of a hundred hides of land. In the north of England the Wapentake corresponded to the Hundred of the southern district. One authority states that a Hundred was a group of inhabitants which provided a hundred fighting-men tor the fyrd, or national army.

There is a strange disproportion between the area of a Hundred in the southern and in the more northern counties; the average number of square miles in a Hundred of Sussex or Kent being about four-and-twenty; of Lancashire more than three hundred. The Saxon population would naturally be far the densest in the earlier settlements of the east and south, while more to the west and north their tenure would be one rather of conquest than of civilization, and the free families much fewer and more scattered.

Other authorities maintain that the system of Shires and their sub-division into administrative units existed long before Alfred's time, not only in this country, but among all German nations. When this people planted themselves on a land, peaceably or otherwise, the family bond was the unit of government. Each family had a hide 
of land-some thirty cultivable acres. It was book-land-private property. Other families clustered around, for the protection and comfort of society. Ten families made the Tithing. A wider personal and territorial division being found necessary for administrative purposes, a group of a hundred familses formed the then considerable community-and hence the Hundred.

Each tithing and hundred had its folk-landland comprising wood, heath, marsh, and pasture -held in common, and which originally formed the mark or boundary of the small community. The quality of the soil and the nature of the surface differing in various parts of the country, also accounted for the varying dimensions of these territorial divisions.

The Hundred and the Tithing constitute the normal or ordinary divisions of an English county ; but there are other divisions and subdivisions, in the names of which may be detected the import of such epochs in the nation's history as the accession of new blood by conquest and settlement.

A Lathe or leth is a larger division of a county, containing three or four hundreds or wapentakes, as in Kent and Sussex. The root of the word lathe is German, signifying people, and was originally applied to subsidized colonists (lati) introduced by the Romans to defend a frontier. The lathes of Kent are in all probability a vestige of the lætic organization of imperial Rome. The English name for the officer who presided in a lathe, was Lath-grieve, or Lathe-reeve, or sometimes Ledgrave.

The border counties of Northumberland, Cumberland, Durham, and Westmoreland have divisions significantly named Wards, as has Lanarkshire on the other side the border. 
The Wapentake was a military division of all fighting men capable of bearing weapons, an organisation due to the Danish intruders, and found chiefly in Yorkshire and other northern counties.

The word Wapentake literally signifies the touching of arms, and was derived from the ceremony which took place on the inauguration of the chief magistrate, when, having dismounted from his horse, he fixed his spear in the ground, which was then touched by the spears of those present. This was evidently the military origin of the Hundred, as adverted to by Tacitus, who, however, also mentions its civil or judicial destination.

While the Hundred indicated a peaceful Saxon settlement, and a Wapentake a Danish defensive settlement, later still came a Norman subdivision which must be classified with the latter. The Rape is a memorial of the violent transference of landed property by the Norman Conqueror-the lands being plotted out for division by the hrepp, or rope, just as they had been by Rolf in Normandy. The Hide, the Saxon unit of land, seems to have been measured off with a leather thong, as the Rape was with a hempen rope. Sussex is the only county which is divided into Rapes as well as into Hundreds or Wapentakes. Wapentakes generally prevail north of the Trent. The presiding officer of a Rape was called Rape-reeve, and like the Lathreeve, acted in subordination to the Shire-reeve.

The counties divided into Wapentakes include Lincoln and Derby (which have also their Hundreds and Sokes, the latter a kind of manorial franchise) ; also Lincolnshire and Yorkshire, which apparently from their great size, were divided into 
thirds, called thirdings or tredings, now corrupted into Ridings. The word " thing " or " ding " is Scandinavian, and signifies a legislative assembly. A Riding, or as in Lincolnshire, a Trithing, was the jurisdiction of a third part of a county, placed under the government of a Reeve or Sheriff. Originally the officer who presided over a Trithing was known as a Trithing-man.

Originally the largest divisional area, the " $\mathrm{Ga}$ " or "Scir" (that is, the Shire) was probably always defined by some natural boundary, as a river, a forest, or a mountain range; and it is tolerably certain that some of the Shires bore the names by which they are still known quite a century in advance of Alfred's time.

At the present day certain of the geographical counties are divided into smaller administrative counties. In Yorkshire they are the Ridings, and in Lincolnshire the Trithings, each having the jurisdiction of a county. In Yorkshire, the largest English county, the divisions are known respectively as the North Riding, the East Riding, and the West Riding.

The extensive area of Lincolnshire is partitioned into three " parts" ; they are known as Holland, Kesteven, and Lindsey.

There is an East and a West Sussex, with Quarter Sessions at Lewes for the former, and at Horsham and Chichester for the latter, though the Assizes are held at Lewes only.

There is also an East and a West Suffolk, administered from Ipswich and Bury St. Edmunds respectively.

In Cambridgeshire the Isle of Ely possesses in some respects the features of a distinct county.

In Northamptonshire the Soke of Peterborough is an administrative county of itself, with peculiar powers. 
A Soke is a locality which has some special " liberty," as the tenants being excused from customary burdens, or the privilege of holding a court within its own " soke" or jurisdiction. Within the boundaries of the Soke of Peterborough are comprised thirty townships and hamlets. The Marquis of Exeter, the " first Civil Lord of the Soke," is (or was) Lord Paramount and Custos Rotulorum having charge of the rolls of the Sessions or the Peace and of the Commission of the Peace.

The administration of justice in the city is in the hands of a bench of magistrates, chosen from the Soke under the nomination of the Custos Rotulorum and approved by the Crown, and these magistrates when sitting at Quarter Sessions had, till the Igth century, powers of jurisdiction far more extensive than an ordinary Court of Quarter Sessions, in that they have the power of trying any offence, including murder, and as for long the Mayor of Peterborough (though reckoned "the least city and the poorest bishopric in England ") was said to be the only Mayor to have the power of convicting and sentencing a man to death.

In Hampshire the mainland is administered as the County of Southampton, leaving the Isle of Wight a separate jurisdiction, though the Assizes for the whole are held at Winchester. In Wales the county of Carmarthen has a territorial division called a Commot - a name believed to be derived from " commonty," a pasture right.

It may be recalled that Cromwell divided England into eleven Districts, over each of which he appointed a Major-General, a military officer to enforce Puritan discipline (I655). Very soon did the country tire of the severities of military 
administration and gladly reverted to the old County system again.

As the familiar unit of local self-government, the "county" is constantly being met with in English literature. In Bret Harte's novels of life in far western California, repeated allusions are made to the " county " and to the "Sheriff," and the limitation of the latter's authority to the confines of his own official area, just as it is in the Mother Country. Or if we turn to the page of history we find Richard Cobden in I848 advocating a plan in what he describes as "constitution tinkering," a subject then enjoying some amount of public attention. He proposed that each county should be governed by an elected assembly to replace the lord-lieutenant and the magistracy who then had charge of most of the local affairs. According to the plan he unfolded-" "The head of this body, or rather the head of each county, to be the executive chief, partaking of the character of prefect or governor of State in the United States. By and by, when you require to change the constitution of the House of Lords, these county legislators may each elect two senators to an upper chamber or senate."

One is suddenly reminded of Cobden's almost forgotten proposals, by the Ulster exclusion clauses suggested for the Irish Home Rule Bill by Mr. Asquith in I9I4. In America, in England in Ireland, it is always the Shire unit which is recognised. 


\section{$\mathrm{XI}$}

\section{THE SHIRE COUR'T AND OTHER IOCAL COUR'TS.}

Saxon Society was constituted on the basis of the family; the whole nation was built on the family tie, cemented by the blood-bond of kinship, which to them implied mutual dependence and mutual responsibility.

Local customs and local laws at this period governed the lives of the whole people. For any practical purposes there was no central government in existence ; there was no " state " dealing directly with the people, and if there were national laws there was certainly no uniform administration of them.

The great bulk of all the justice was done in the local courts-the Shire Moot and the Hundred Moot-the king's own court being for the protection of the royal rights, and a court for the causes of the king's barons.

Originally, when as the national assembly as well as the judicial court of the tribal kingdom, held in the open air beneath the spreading shade of some mighty oak, the Scir-gemote, or Shire Moot, had possessed legislative functions. In London "Paul's Cross" was the meeting-place for one of the chief Folk motes of the city.

In the later Anglo-Saxon times a Shire Moot or County Court was held at the beginning of May and October, in which all the thanes were entitled to a seat and a vote. Its functions were judicial 
and it was presided over by the ealdorman (or the earl), with the assistance of the bishop. Hume justly remarks that among a people who lived in so simple a manner as the Anglo-Saxons, the judicial power is always more important than the legislative; and the thanes were mainly indebted for the preservation of their liberties to their possessing the judicial power in their county courts.

From the foundation of the kingdom the Shire was the largest administrative division; the Sheriff occupied the position of royal steward in it, and has survived all the other functionaries.

The County Court remained in Norman times as the tribunal before which almost all the criminal charges were determined. All the land-owners of the county under the presidency of the Sheriff and Bishop, formed the Court. They all took part, or bad a right to take part, in a criminal trial, and they all looked on to see whether due proof of guilt or innocence was given. Into the methods and processes employed it is scarcely necessary to enter here; but, as is well known, they included Trial by Ordeal, and the system of Compurgation. In the latter, the neighbours of the accused swore to a belief in his innocence, the testimony of each compurgator being estimated according to a scale of " worth "-an earl's oath, for instance, being equal to the oaths of six ceorls (the freemen cultivators of the soil) and so on. If the aggregate value of the oaths fell below the prescribed sum, the accused was found guilty. If the accused put himself upon the trial by ordeal, the weight of the pot of iron he was to bear, or the depth to which he was to plunge his arm into the hot water, was scrupulously pre-appointed by the law. The Assembly looked on. In trial by compurgation they added up the amount of the 
oaths; in trial by ordeal they watched the effect of the hot iron, or hot water, upon the skin of the accused person; and that was all they had to do. It was over the solemnity of their fellows' judgment, judicially exercised, that the Sheriff of the county and the Bishop of the diocese presided. When, in process of time, the Bishop disappeared from this civil court, the Sheriff, as direct representative of the King's authority, became the sole president.

To assist in the dispensation of justice there seems to have been another class of official, called Deman in the original Saxon, but generally translated judices in the Latin, who took part in administering and accepting the oaths of Compurgators. It is difficult to realise the precise status of this officer in a court where the suitors were the judges, but conceivably the judex may have been the "doomsman" of the Hundred. In any case he acted as deputy to the Sheriff in the administration of justice.

The sovereign of a large or considerable kingdom found it impossible to wield the sword of justice personally in every part of his realm, and therefore in the evolution of the state, the administration of the law was from the first a delegated function. In England the earliest and most elemental form of this delegated authority, with a criminal jurisdiction, was found in the Hundred Court.

Each Tithing or Township had its own local court, with varying amounts of jurisdiction, and subordinate to the Hundred Court, which again was subordinate to the County Court or Shiremoot. Hundred Courts were held monthly, and the Shire Courts at least twice a year. 
" The civil division of the territory of England (says Stephen in his Commentaries) is into counties, of those Counties into Hundreds, and of those Hundreds into Tithings or towns. This division is of remote and undefined antiquity; and was not peculiar to England, similar distributions having been in use among several nations of the continent. As to the Tithings, they were so called from the Saxon, because ten freeholders with their families composed one. These all dwelt together, and were sureties or free pledges to the king for the good behaviour of each other ; and if any offence was committed in their district, they were bound to have the offender forthcoming. And therefore antiently no man was suffered to abide in England above forty days unless he was enrolled in some Tithing or decennary."

One of the principal inhabitants of the Tithing was annually appointed to preside over the rest, being called the Tithing-man, or Head-borough, names which speak their own etymology. In some counties a similar officer, elected because he was deemed to be the discreetest man in the borough, town, or tithing, was known as the Borsholder, or borough's-elder. As a Headborough came to be regarded as a sort of petty constable, a borsholder would be a superior kind of constable. The commonalties of some of the larger townships elected officers with magisterial powers; but as a rule the Town Moot concerned itself with other and more intimate affairs.

At the Town Meeting all questions of local moment were considered and decided. For instance, each year the strips of cultivated land, scattered about the parish, were at these meetings fairly divided so that each man stood an equal chance of having good and bad in his holding. 
The question of cropping was settled to the satisfaction of the majority of the townsmen. Regulations were made for the grazing of the common lands, and also of the waste land between the townships. In fact every communal interest was discussed and fairly arranged.

With the advent of Norman rule, each village and township became a feudal manor, or part of a manor. As a ruling class, the Normans had sense enough to preserve the local courts and customs, and, incidentally, the powers of the Sheriff became considerably enlarged.

At a later period the manorial courts of the feudal lords were fiercely attacked by Edward I., who tried to extend the jurisdiction of the Shire and Hundred Courts as well as the popularity of the Assize Courts; his object being not only uniformity in the administration of justice, but a vindication of the authority of the central government. Another blow dealt at the old manorial jurisdiction was the rising power and increasing usefulness of the unpaid justices.

At the Hundred Meetings, where the Bishop sat with the Elderman to look after the interest of the church, the Sheriff also being present in the capacity of the royal steward, to safeguard the king's rights, all disputes were decided, and criminal offenders punished according to law or custom. Neither the Danish kings or the Normans interfered with the English practice of preserving the peace by the method of mutual responsibility, and open trial in the Hundred Courts.

At the Hundred Court the landowners of the district and their stewards were entitled to be present, or if unable to be present might be represented by certain of the freemen. The Hundred was governed by a High Constable or Bailiff. 



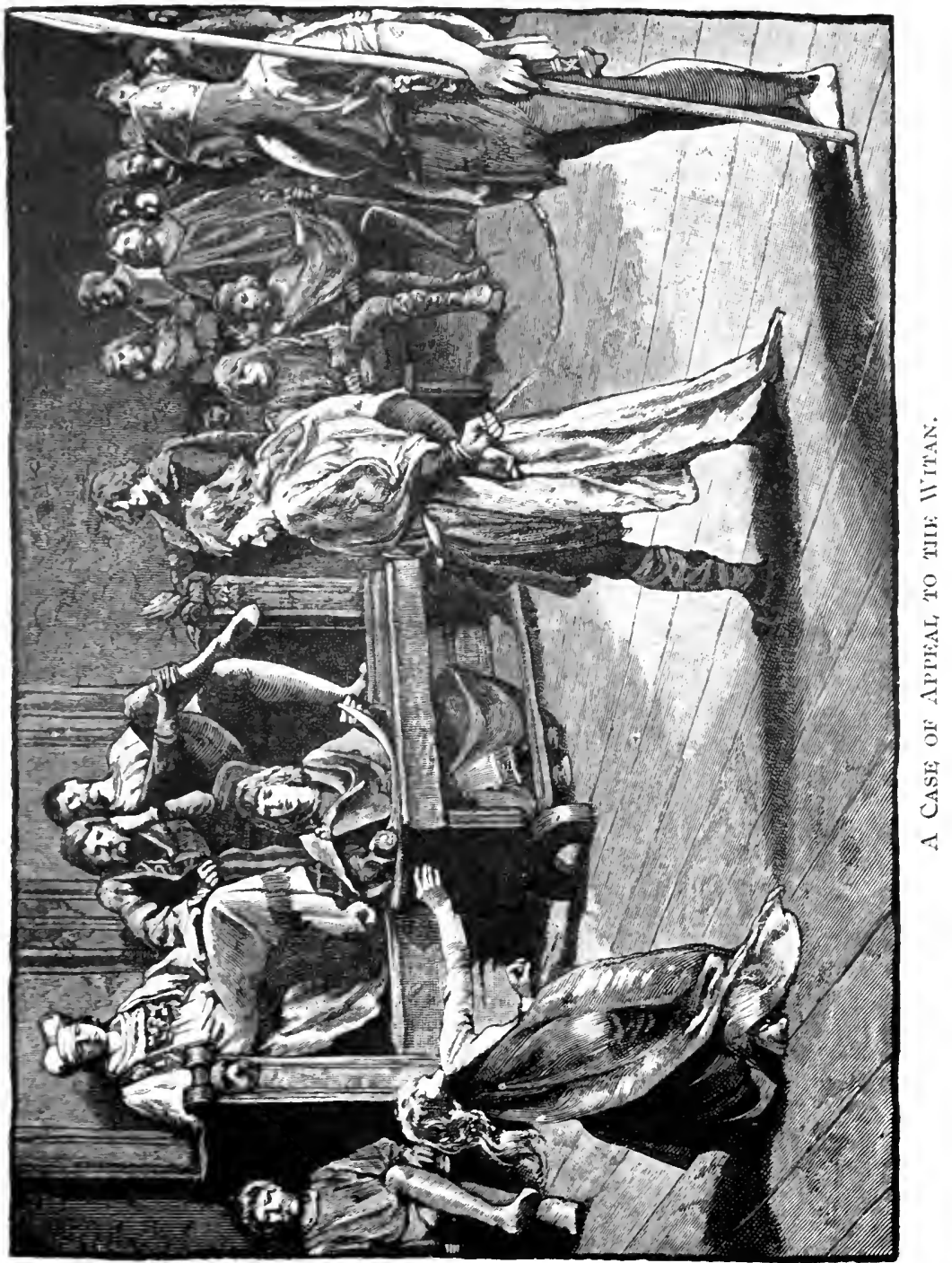


At the Shire Court, also, the Church took a part in the proceedings; it was not till after the Conquest that the Church asked for, and obtained, independent ecclesiastical courts with a privileged jurisdiction. Almost concurrently with the withdrawal of the Bishop from the Shire Court, the powers of the Eldermen waned to vanishing point while those of the Sheriff steadily increased.

Henry I. sent out Commissioners to the Hundred and Shire Meetings to see that justice was done in them, and that the taxes were paid.

Above the Town, the Hundred, and the Shire Courts was the Witan, or assembly of wise men, who advised the king. As in Saxon and Danish times, government through the great earls had proved unsatisfactory, the Conqueror was careful to avoid this form and to rely more on the advice of the Eldermen, who in some sense, at least, were representative of the Shires.

Our Saxon ancestors, like all the ancient German peoples, maintained the right of meeting to advise their king in council ; so, in all the countries where the feudal system became established, there arose a national council which, in different countries was known by different names, as States General, Cortez, the Grand Assize, or Parliament, In this country the Norman Conqueror and his successors had assemblies, differently constituted under the names of Concilium, Magnum Concilium, andCommune Concilium. To these none were summoned but archbishops, bishops, abbots, priors, earls, and barons.

In this national assembly there always existed an element of county representation, the Sheriff of each Shire being directed to send up a certain number of freeholders or royal tenants to talk with the king-it was in fact a " talking meeting " 
or parliament, the deliberations at which were carried on in Latin or Norman-French. These representatives were chosen by the free votes of their fellows at the Shire-moot, or Hustings as it came to be called later.

The Hustings, literally, was an assembly (or "thing") of householders. The Borough Courts were first called Hustings, and thence the name became applied to the assemblies at which Borough (and later, County) representatives in parliament were elected.

Shire-Moot and Folk-Moot were synonymous terms, the folk signifying the tribe. When the union of the kingdoms had been effected, it was doubtless found difficult, even on special legislative occasions, for the people to attend. The powers and functions of the Folk-Moot then merged into the Witan or national council of Wise Men, which consisted of the bishops, abbots, and the chief officers of the royal household, the ealdormen of the shires, and the King's nearest kinsmen and chief tenants. These men, considered to have the highest knowledge of political affairs, advised the King, carried on the administration, and prepared the laws for the acceptance of the people.

Spelman says that originally the Saxon FolkMoot held its annual meeting on May-day. This learned antiquary explains it as a convention of Bishops, Thanes, Aldermen, and Freemen, in which the laymen having first sworn to defend one another and conjointly with the king maintain the laws of the realm, then proceeded to consult of the common safety.

It was under the absentee King, Richard I., that the Shire Court reached its fullest activity, and made for the fullest form of local self-govern- 
ment in the county, which could be enjoyed under feudal conditions, from the year II94 its influence in affairs was recognised time after time by the union of a number of shires into a central assembly for the discussion of some matter of grave importance. In 1226, for instance, knights of the shire were called together to discuss certain disputed articles in Magna Charta.

It has therefore been suggested that, when calling his first national parliament, Simon de Montfort borrowed the idea of organising a central assembly from the practice, which had then prevailed for some time, of four leading knights going round to arrange for a representative body of twelve knights or freeholders for each Hundred, into whose hands certain well-defined powers of local government were fully committed. The first House of Commons is claimed to be an expansion of this idea.

It is a weighty suggestion, no doubt; there is another of almost equal significance-that our boasted system of trial by jury can also have its origins traced to an old Shire Court practice, or possibly to that of the Hundred Court below it. By the laws of Ethelred (about 675 A.D.) a court was to be held in every Hundred, in which twelve men (duodeni viri) of free condition and mature age, together with the presiding officer, " shall swear not to condemn the innocent or acquit the guilty." But, it must be remembered, these laws were promulgated to regulate Trial by Ordeal and Trial by Compurgation, and the "twelve men" therein mentjoned were merely a body of assessors to assist the Earl or other officer who presided in the Court ; and the duties performed by them can scarcely be claimed as similar to those discharged by a modern juryman. The germ of the idea 
which gave us the jury system is certainly there ; but whether as a relic of Roman law adopted by the Saxons from the vanquished Celtic inhabitants, or brought over from the forests of Germany by them, no man can say.

The Hundred Court was utilised in ro85 to collect the sworn information upon which the Domesday Book was compiled. The chief men in each Hundred, who were called upon to give evidence to the compiling clerks, were designated jurors. The term, however, did not convey the signification since attaching to it, as men called upon to judge and award-but merely men put on their oath.

Among the Saxons the Shire Court had relied chiefly on compurgation, and trial by ordeal. The Normans introduced the wager of battle. Henry II., a little later, is believed to have introduced the jury system in a modified form. In his reign the Shire Court first accepted the oaths of those persons who were considered most likely to know the truth of the case under trial. This procedure in time developed into the jury system as we know it; a body of men knowing nothing whatever of the case, being called upon to weigh the evidence of those who did know.

To trace the history of the Shire Court is to discover the origin of the Parliamentary idea, and the rudimentary beginnings of democratic government. 


\section{XII \\ THE TOWNS}

Our Anglo-Saxon forefathers were not towndwellers; and in many ways they showed their dislike of walled towns when they settled here. With them land was the accompaniment of full freedom, and the freeman was the freeholder. Therefore, on their first arrival, instead of crowding together in cities, they preferred to live apart in farmer commonwealths, each of which was jealous of its isolation and independence, and to maintain which, each agricultural settlement was girt by its own " mark" or belt of waste land. But even in a nation of sturdy farmers, the evolution of the burgh is inevitable-though these Teutonic invaders had destroyed Roman cities, their children were doomed to the erection of many Saxon burghs.

Though our subject treats nominally of the Shire, the evolution of the Town cannot be entirely ignored.

Though with the Saxons the Tun or Township was the smallest, if not also the least important of governmental areas, it has come in many instances to rival, and even to outstrip, the Shire, in all material factors-except, of course, areaas population, wealth and political influence. Something, therefore, requires to be said on the growth and grading of Towns.

Cities, boroughs, and corporate towns were not always absolutely independent of county sup- 
port. In early times the walled towns, being strongholds somewhat in the nature of local " cities of refuge," received aids from the county in which they were situated, and sometimes even from a neighbouring county. Thus we find Ipswich, in the reign of John, had its walls and ditches repaired by the aid of the county, assisted by the county of Cambridge. An entry in Domesday Book discloses that the responsibility for the upkeep of the walls and bridges of Chester, lay upon the whole county.

Sir Edward Coke estimated that in his time, some three centuries ago, there were in England and Wales about 8,800 towns, several of them having small appendages called " hamlets," which were noticed in the Statute of Exeter (I4 Edward I.) wherein also occurred the terms " entire vills" and " demi vills." Sir Henry Spelman conjectures " entire vills" to have consisted of ten freemen or frank pledges, " demi vills" of five, and hamlets of less than five. "These little collections of houses are sometimes under the same administration as the town itself, sometimes governed by separate officers; in which last case they are, for some purposes in law looked upon as distinct townships."

"Tithings, towns, or vills," says a later authority, "are of the same signification in law, and are said to have had each of them originally a church with celebration of divine service, sacraments and burials; though that seems to be rather an ecclesiastical than a civil distinction. The word town or vill is indeed, by alteration of times and language, now become a generical term, comprehending under it several species and varieties. These towns contained each originally but one parish and one tithing; though many of them 
now, by the increase of inhabitants, are divided into several parishes and tithings ; and, sometimes, where there is but one parish, there are two or more vills or tithings."

Towns are distinguished from each other (legally) as being either corporate or not corporate; the townsmen forming, in the first kind a corporation, that is, a society, with certain legal powers, properties and capacities.

There are Market-towns, which are towns entitled by some old privilege or franchise to hold markets in their public streets and thoroughfares. Cities (in England) are those towns which areor have been in the past-sees of bishops; there being no connection between a city and a see, though the bishopric be dissolved, the town remains a city still.

A borough is a town that sends, or has sent in the past, a burgess to parliament; it is sometimes known as a " mayor-town."

Of all the towns in this country, London is the most privileged, being the capital and the most important, rejoicing in every civic franchise possible. London is the exception to all rules.

When a state organism was being given to England by its Norman Kings, London occupied a peculiar place in the institutional life of the country; a place of independence, strength, and prestige of a really remarkable kind, though it is generally unnoticed or unemphasised by historians. The records, though fragmentary, clearly show that London stood apart from the life that surrounded it in the Anglo-Saxon period.

In the earlier part of the period it had been the chief town of the East Saxons; but for recognition as the capital city of a united England it had a strong rival in Winchester, the Hampshire capital 
of the West Saxons. Its Roman walls at the first had not attracted the Saxon invaders, for they were not town dwellers ; the Danes, however, had made it their head-quarters, and after they had desolated it, King Alfred recovered and rebuilt it.

The Conqueror had found London the chief trading town, and had ordered it to be fortified by the erection of a strong castle or tower. Its citizens were freed from taxation, it was allowed to have its own Courts of Law, and by Henry I. was even given authority over Middlesex. While London remained the largest city, Middlesex was but the smallest of the Shires.

London is not included in the comprehensive survey of Domesday. It did not become the seat of Government until the late period in which it grew out to, and absorbed Westminister, " the home of royalty."

That eminent authority, Sir Laurence Gomme, who has attempted to trace the origin and growth to maturity of " the English institution which is contained within the shell of London city," makes one realise that there is something almost mysterious in this complete separation of London from the rest of the country.

This writer says-

" London remained so long independent of English polity because that city alone, in the midst of the primitve and typically tribal society that now flooded the country, retained the character and the highly-developed institutions of a city of the Roman world-state; she stood like a strong tower above the tide that overwhelmed every other centre of the Roman civilization of England." 
There was in London a prolonged resistance by its isolated garrison and higher civilisation to the assaults, first of the Anglo Saxon, then of the Dane, and then of the great Norman and Angevin statebuilders. London's position and numbers having saved the community from mere stamping out and scattering, her own law, custom, and government, by sheer force of superiority, withstood the absorbent power of the barbarian society about it. And this at the period when the Shire system was being inaugurated. Only by degrees AngloSaxon custom and spirit soaked into the city from without the walls. London elections were not English elections-its Anglo-Saxon Folk-Moot was always striving to be dominant but never actually became dominant.

When the Norman came London was still independent, though ranged with the rest against him on the hill behind Hastings. The epoch of the charters to London, begun by the Conqueror, was the epoch of the gradual discovery by the new statesmen of London's peculiar body of prescriptive rights and customs, claimed as London's due against every other power, into rights and customs expressly granted by the Crown out of its new national sovereignty. In the end the robust life of the young Einglish State, now at length made one, played freely through the city, obliterating a thousand traces of the rule of ancient Rome and blotting out the memory of what they meant.

The first Mayor of London was Henry FitzAilwin, who was appointed in II89, and held office for twenty-four years. In I354 the holder of the office was dignified with the title of " lord-mayor."

The Mayors of London, York, and Dublin, and the Provost of Edinburgh have long had the 
courtesy title of lord, which brought with it the other courtesy designation of Right Honourableand a similar honour has in recent years been extended to the Mayors of the newer populous cities, like Birmingham, Manchester, Liverpool, Bradford (Yorks.), Bristol, Hull, Leeds, Newcastleon-'Tyne, Norwich, Nottingham, Sheffield, and Cardiff.

The first lord mayor to go by water to Westminster (for the royal ratification of his election) was Sir John Norman, who in I 453 thus instituted the Lord Mayor's Show.

The symbolical cap and sword of the Lord Mayor of London were given to Sir William Walworth by Richard II., for killing Wat Tyler. In "The Nine Worthies of London" (I592) we are told that the Mayor first arrested and then stabbed the rebel chief, of which died.

A costly hat his Highness likewise gave

That London's " maintenance" might ever be ;

A sword also he did ordain to have

That should be carried still before the Mayor

Whose worth deserved succession to the chair.

In course of time the creation of diverse bodies for diverse objects, tended not a little to complexity-the single community of London, for instance, is managed by I44 local governing authorities, with 4343 members elected in various ways-but then the population dealt with is half as numerous again as that of Bulgaria.

In the centre is the City, nursing the ancient privileges and property that belong to all ; outside is County Council London, with its 28 separate boroughs and 30 separate poor law districts; beyond extends the area of Main Drainage London, beyond that the area of Water London; still further is the area of Police London, stretching from Cheshunt to Epsom and 


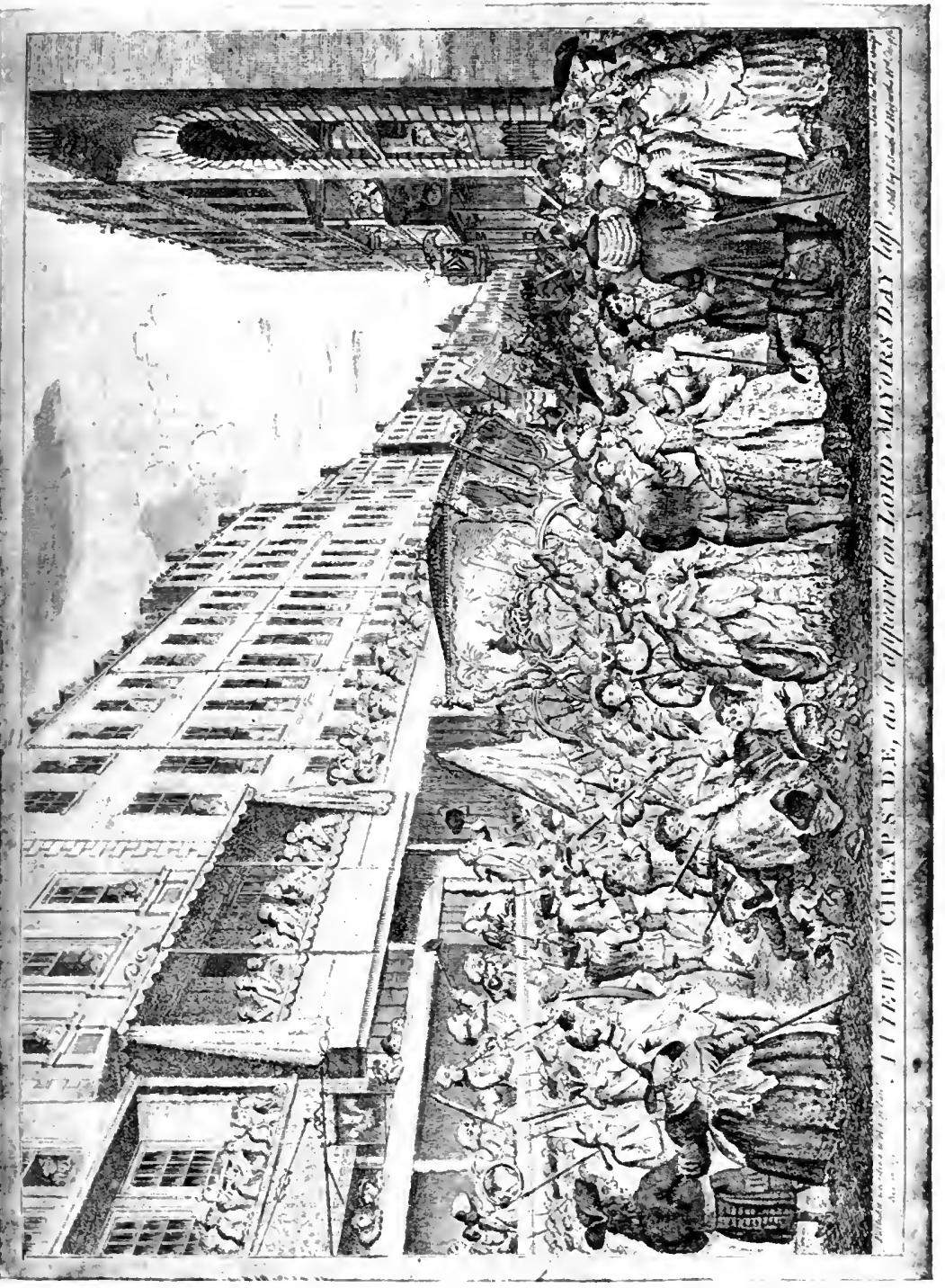



from Romford to Staines. No two of these areas are co-terminous and all are strewn with authorities, often conflicting in interest and activities, all independent and all spending the ratepayers' money. Within the II7 square miles of the County of London there are IOI authorities, spending over $f 25,000,000$ a year; within the 693 square miles of Police or Greater London there are 262 authorities, spending some $£ 35,000,000$ a year.

There is no central control and no co-ordination ; with the result that there is much waste, great confusion, and some injustice.

And so London, with ever increasing population and accession of wealth, has grown from greatness to greatness. Other trading towns and commercial cities have followed in the same course of material prosperity. Inasmuch as many of these prosperous towns have extended their municipal boundaries, they have grown in area at the expense of the county area. But whether this shrinkage of the county areas is for the good of the general community is doubtful - there is not only the encroachment of the town upon the countryside which is not hygienically desirable, but there is the risk of a further impoverishment of the rural districts, where local government is already handicapped by the smallness and inelasticity of the rateable values chargeable. 


\section{XIII \\ THE " SHIRE MAN"}

The division of the country into a number of administrative areas called Shires, necessarily implied deputed authority on a large scale; it was a system which called into being for each Shire a functionary of no little importance, one who for local purposes was the representative of royal authority, vested with very considerable powers. In the earlier stages of state consolidation the over-king had delegated his authority to the Ealdormen of the Shire, who was not unfrequently a descendant of the old tribal kings. But with the later organisation of the shire system, this delegated authority was placed in the hands of a local freeholder of the better sort, chosen by his fellows, though sometimes nominated by the king; he was specially charged with the care of the royal estates within his jurisdiction, and the collection of all dues and fines for the royal treasury.

In the creation of this constitutional officer we seem to see the first glimmerings of a national consciousness, and the growth of that consciousness is traced in the gradual evolution of his office.

This was the Shire-man-in Saxon times the Scir-gerefa or Shire Reeve, and in the northern parts, the High Reeve. But by whatever name he was known, he was a constitutional officer, and his office, it is noteworthy to observe, has survived a thousand years after that of 
the Ealdorman has ceased to be known, and that of the Earl-or Count-has ceased to have any official connection with the county. It may have been that when the custody of a Shire was committed, as at the first division of the kingdom, to the hands of an earl or of an ealdorman, either of these rulers was found of tendencies too autocratic for the independent spirit of the people, and it was therefore deemed expedient to associate in the government another official of a more representative character, one more amenable to well-ordered influences. It is not difficult to understand how, under conditions such as these, the office of Sheriff came into being.

As bailiff of the shire, acting on behalf of the king, appointed annually with the approval of both king and people, the Sheriff became the constitutional head of the county; and it was as such that his office endured.

The Sheriff was at the first chosen by the inhabitants of the several counties, in confirmation of which it was ordained by statute 28 Edward $I$. that " the people should have election of Sheriffs in every shire when the shrievalty is not of inheritance."

For in some counties the office was once hereditary, as it was in Scotland, till the heritable sheriffs were deprived of their powers (which extended to the trial of criminals) by an Act of I748. After the Rebellion of I745 the Imperial parliament found it advisable to abolish all hereditary jurisdictions in Scotland which were associated with the ownership of land and titles of rank. In England the Earl of Thanet was hereditary Sheriff of Westmoreland, and the office once descended to, and was executed by, a female of his line, in the person of Ann, Countess 
of Pembroke, who exercised it in person, sitting on the bench with the judges at Appleby Assizes.

The Sheriff of Northumberland was High Treasurer of the county, and being entrusted with the defence of the borders, was endowed with extraordinary powers and prerogatives, even to the retaining of some of "the issues of his sheriffrick to his own use."

In Northumberland and the adjacent border counties, the Sheriff in olden times appointed officers known as the County Keepers, whose chief duty was to afford protection against, or make good, losses occasioned by reivers from the Scottish side of the Tweed.

Although the process of popular election, which was the more generally observed, appeared to give the appointment that democratical tinge which is in consonance with the English constitution, the person elected was always required to receive the royal approbation. The elected of the people required the confirmation of the king.

These elections growing too tumultuous, an end was put to them in the ninth year of Edward II., when it was enacted that from thenceforth the sheriffs should be assigned by the Chancellor, Treasurer, and the Judges, as being persons in whom the same trust might with confidence be reposed.

Originally the Scir-gerefa (conf. the other Teutonic form, Shire-graf) was the executive officer appointed by the king to carry out the decrees of the Court, to take charge of prisoners, to levy distresses, and so on. He was the legal official before whom accusations had to be enrolled. At first he acted only as assessor, but in process of time became joint president, and ultimately sole 


\section{The " ShIRE MAN"}

president. The Sheriff's court survived the Norman Conquest, and in the opinion of Hallam it contributed in no small degree to fix the liberties of England by curbing the power of the feudal aristocracy.

When the Earl (or the Ealdorman) had ceased to attend the County Court, and the Bishop had his own court, the Sheriff became the sole judicial officer in the shire, and so remained for a time--till the appointment of Justices in Eyre II89, and then of Coroners and Justices of the Peace in II95. By the first of these innovations Henry II sought, amongst other reforms, to secure greater uniformity in the administration of the law; and at the same time, of course, to carry royal justice into every quarter of his kingdom.

As already suggested (Chapter XI.) the origin of trial by jury-which no one reaily knows-is associated, and not remotely either with the history of the office of Sheriff. In the reign of the Conqueror a dispute arose about some land which the Sheriff claimed on behalf of the king. "All the men of the county" (by which we are to understand the "Sectores," or the landowners of the ristrict who acted as judges in such matters), were assembled and sworn to say the truth. Eventually they found for the Sheriff. The judge, dissatisfied with the verdict, directed the men of the county to choose out of their number twelve who should, upon oath, confirm the verdict if they thought fit. This they did, though authorities now agree that the selected twelve were not exactly jurymen. The legal existence of jurors, in the sense of the awarders of a judgment, was first recorded under the Plantagenets, a century or so later. 
The known and established facts are that the jury system was found to exist in a very rough and primitive form in the Conqueror's time, and that under the Plantagenets it was carefully adjusted and improved to meet changed conditions and altered circumstances. All sorts of inquests, inquiries, and inquisitions, to do justice between man and man, were brought through the Sheriff, or other local officer, before a body of men sworn to speak the truth, and who were chosen by reason of their character and local knowledge; and in this assembly of sworn "Recognitors," as they were called, we undoubtedly have the first germs of the modern jury. The first steps in the evolution of the system are well known.

By the Assize of Clarendon, an order of the King's Council made in II64, local juries were to present criminals for trial before the Shire Courts. It was enacted that Inquest be made through each County and through each Hundred by twelve " lawful " men of the Hundred and by five "lawful" men of each Township, by their oath that they speak the truth. These men were to present to the justices all persons of evil fame who must then submit to the test of the Ordeal by fire or water.

Further legislation followed in the Assize of Northampton, promulgated in II94, prescribing the method of appointing the Recognitors, in whom we may recognise the beginnings of the Grand Jury. There is a great tangle of subsequent statutes, rights, and customs; in the application of the Jury system to both criminal and civil trials; in the institution of the Petty Jury to test the truth of the Recognitor's presentments; and at last, after the abolition of Ordeal, to make a judgment and return a verdict. 
Confessedly the part of the jurymen at first was rather that of witnesses than of judges. But the system which encouraged the accused, or the litigant, to lay his case before a jury of his fellow men, or as it was expressed, to " put himself upon the country," was an institution worthy of the administrative genius of the English people.

Sheriffs are said to have been nominated for every county in England by William I in I079, though this is doubtful. In the new language of the law courts, he then became vice-comes, that is, deputy count; and by that name he is still legally known, though no longer subject to an earl. To him, by letters patent, was committed the custody of the county, and in his hands were other than judicial matters affecting county governments.

This, the most ancient constitutional officer in the realm, has therefore to be considered in other aspects than as a judicial functionary. The Sheriff was the earliest revenue officer, being legally responsible for the collection of the royal revenues arising from litigation and taxation, as well as from the king's landed estates.

He collected the royal rents and ferms, or contributions of towns on the king's demesnes; and (as Escheator) dealt with escheats and fines, and forfeitures for scutage, assarts, and other feudal burdens.

Not only was the custody of the county committed to him in a financial sense, but he was also charged with the important duty of raising the shire's quota to the national army, and presenting 1t, when called upon, in a state of efficiency. He was expected to head, if not to lead, the Fyrd, or county force. 
The basis of national defence in Anglo-Saxon times was an obligation not only to serve in arms, but to equip oneself and to support oneself entirely during the campaign. And the levy was always made by counties. In return for this service one became a "freeman." Nowadays a minority regards military service as a loss of freedom, whereas it used to be the price at which one attained citizenship.

The Sheriff as a military officer does not occupy a conspicuous position in history; the form of feudalism introduced by the Normans did not encourage the old system under which the Saxons had raised a national force by means of the "Fyrd." From time to time the Fyrd, which was in essence a territorial defence army, was used to supplement the feudal levies-the liability of the feudal army did not extend to more than 40 days in a year-but this was entirely a misapplication of its purpose.

The first precedent for employing the Fyrd on foreign service was created by William Rufus. This unscrupulous monarch, having assembled as large an army as possible at Hastings, collected from the men the money entrusted to them by their respective counties for the expenses of the campaign-then cancelled the expedition and pocketed the proceeds!

The Fyrd was the general levy of the shire, liabulity to military service extending to every man between the ages of $I 6$ and 60 . At the call to arms the men of each township marched in families, with their reeve (and in Christian times, with their parish priest) to the meeting-place of the Hundred; thence the united townships marched under the Hundred-man to the Shire meeting-place, where the Ealdorman (and the Bishop) took the command. 
This force at a later period was called the Posse Comitatus, by the latter word being understood a county composed of hundreds and tithings.

The Posse Comitatus was the whole force of the county-that is, all the male members of the county over fifteen, who may be summoned by the sheriff to assist in preventing a riot, the rescue of prisoners, or other unlawful disorders. Clergymen, peers, and the infirm. were exempt from such summons.

Originally the Fyrd had consisted of two elements. The bulk of the shire levies consisted of all freeholders, men in the prime of life, yeoman and gentry, who need only discipline to make them the very best fighting material. Supplementary to these were the house carles of the king and his ealdormen, fewer in number, but better trained and always well disciplined. The levies were not bound to serve out of their own shire, except under certain defined circumstances.

In 1328 the first Parliament of King Edward III. enacted: " . . . that no man be compelled to go out of his shire but when necessity requireth and sudden coming of strange enemies into the realm; and then it shall be done as hath been used in times past for the defence of the realm."

With the Saxons the Fyrd (or army) was actually a territorial force, each locality supplying its quota of fighting men for national defence. Moreover, the labour of all the inhabitants could be requisitioned for the making and mending of the roads, bridges and forts in the neighbourhood.

The introduction of the Norman form of feudalism naturally made some change in the character of this national militia when landholding, instead of land-owning, became the basis 
upon which depended the provision of an army (and incidentally, the enforcement of justice). William II. made use of the Fyrd in his quarrels with the barons, using this English force as quite distinct from his feudal supporters. The Fyrd was again revived as a national militia by Henry II., who embodied it for the defence of the country ; and in I285 the Statute of Winchester continued the Fyrd by legal enactment. A blow, however, was struck at this ancient method of raising an army by the rise of baronial retainers, attached to their leaders by " livery and maintenance," which began to grow up in the reign of Edward III.

By the Tudor period, and when the old method of raising military forces by feudal levies was fast dying out, a new one had to be inverited to take its place. The Sheriff was superseded, as the military commandant of the county, and his place was taken by an entirely new functionary known as the Lord Lieutenant.

To him was transferred the power to raise the posse comitatus, or county forces, formerly invested, under certain conditions, in the Sheriff. Macaulay, however, does not hesitate to show the more ancient officer discharging this military function in Elizabeth's reign; as thus, in his famous ballad, "The Spanish Armada"-

With his white hair unbonneted, the stout old sheriff comes,

Behind him march the halberdiers, before him sound the drums. 


\section{XIV.}

\section{THE COUNTY ESCHEATOR}

Under the Normans the Witan became the Great Council, a strong central authority, attended by the great barons and chief tenants of the king, the bishops, and the heads of the great monasteries. As a consultative council it held periodical meetings for the transaction of business of state ; and between those meetings a small body of advisors, who in course of time evolved into regular officials, carried on the affairs of the King's Court. The Council gave its added authority to the mandates of the king.

A branch of the King's Court was set up to deal with the financial matters of the realm. This was the Exchequer Court, in which trained clerks were employed, under the direction of capable officials. These officials stationed at Westminster, were appointed to receive all accounts and payments from the Sheriffs.

The fixed revenue consisted of the king's demesne lands within the counties, of the county mints (the "moneyers" were liable to be summoned to Westminster to take part in the trial of the pyx, when, for any deficiency in weight or fineness of their coin, the manufacturers were punished as traitors) and of certain boroughs which paid annual sums as the price of their liberties. There were also rents incidental to the forests, and mining and other royalties. Danegeld was regarded as a fixed revenue till the time of Henry 
II. There was also a considerable casual revenue arising from feudal fines and forfeitures.

The Sheriff, as Escheator, had to collect, bring into the Exchequer, and there account for the Ferm of the Shire; that is, the fixed rent of the old public lands and royal domains. At the Norman Conquest these rents, known as Sheriffgeld, together with the Danegeld (a tribute of two shillings on every hide of land in the realm and so called because it was a " gold" levy first laid upon our ancestors by the Danes, and was in fact the first tax collected in money in this country), and the various feudal fines and amerciaments, constituted the whole of the national revenue.

An Escheator was the officer, connected with the seignorial interests of the Crown, who played an important part in county organisation, when feudal dues were rather a large consideration at the Exchequer.

Another term just used which needs glossarial explanation is Ferm-a word with an interesting history which cannot be given better than the learned Blackstone has given it-

"Farm or feorme is an old Saxon word signifying provisions ; and it came to be used instead of rent or render, because antiently the greater part of rents were reserved in provisions; in corn, in poultry and the like; till the use of money became more frequent. So that a farmer, firmarius, was one who held his lands upon payment of a rent or teorme; though at present by a gradual departure from the original sense, the word farm is brought to signify the very estate or lands so held upon farm or rent."

After the Conquest the system of national finance was reformed, and the Sheriff was. brought 
into contact with three great officers of state, the Justicier, who was almost a vice-roy; the Chancellor, who was the King's secretary, and the royal Treasurer. The Sheriff, in discharge of his duties as a revenue officer, came up to the capital to meet these high officials twice a year in the Court of Exchequer.

The business of the ancient Exchequer was primarily financial, and the principal accountants were the Sheriffs, who were bound as the King's principal financial agents in each county to give an account of their stewardship twice a year, at the Exchequers of Easter and Michaelmas. Half the annual revenuewas payable at Easter, and the balance at Michaelmas, when the accounts were made up for the year and entered on the Pipe Rolls.

The Treasurer charged the accountants with their fixed debts, which he read out from the Pipe Roll, or great roll of accounts, wherein were written the decision of the court, as to the indebtedness of each Sheriff, and all other accountants having business at the royal treasury.

The Treasurer of Henry III. is said to have been provided with a " checker " to ensure the accuracy of his accounts, an official now represented by the Chancellor of the Exchequer. The Lord High Treasurer disappeared in I7I4 when George I. put the office in Commission, since which the Chancellor has become the chief official at the Treasury.

The Court of Exchequer is said to have derived its name from the " chequed" cloth (scaccarium) resembling a chess board, which covered the table there, and on which, when certain of the king's accounts were made up, the sums were marked and scored with counters. 
The abacus, or other mechanical contrivance for keeping accounts, was almost universally in use before the introduction of the Arabic notation. In England the Treasury department was named originally " the Tallies," from the method of accountancy therein employed.

This ancient exchequer practice was a primitive method of reckoning and keeping accounts by means of wooden tallies. Two slips of wood, precisely the same size, were placed together and notches cut in them; or sometimes the indentations were cut in one piece, which was afterwards split down into two equal and corresponding parts; one stick was kept by the creditor, the other, " a tally," by the debtor. The word tally is derived from the French taillier, to cut.

The tally was generally a willow or hazel stick, about an inch in depth and thickness and roughly shaped like a thick table knife.

The Exchequer tallies were notched according to a graduated scale, a notch of one-and-a-half inches representing $£ I 000$, a notch of one inch standing for $£$ IOO; three-eighths of an inch for $£$ IO; half a notch of that size representing $\ell_{I}$; threesixteenths of an inch, Is., and the smallest notch Id; half pennies were represented by sma1l holes. The account of the transaction was written on the two opposite sides, the piece of wood then being split down the middle, through the notches; one half, called the tally, being given as a form of receipt to the person making the payment, while the other half, called the counter-tally, was kept in the Exchequer.

The payments were then entered into account books or rolls, and written records of the transaction duly kept. 


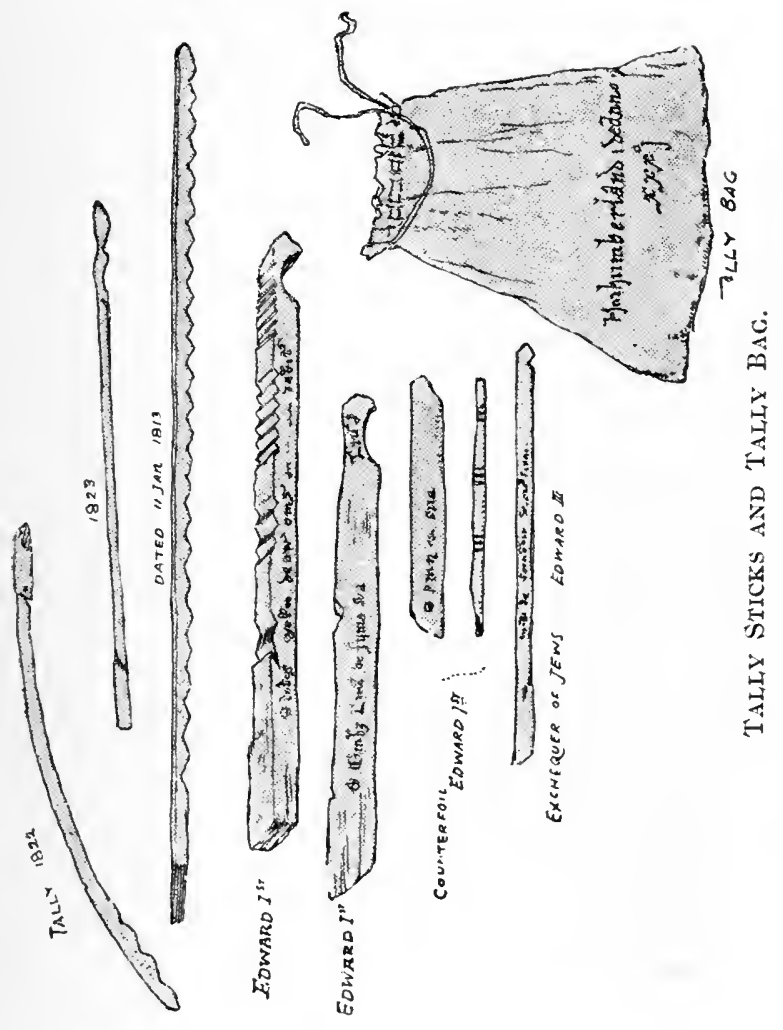



This method of reckoning continued in use in the Exchequer till I826, when the last of the officials known as Chamberlains of the Exchequer passed away, and the system came to an end. In I834 the returned tallies were ordered to be destroyed, and in pursuance of this order were utilised as fuel for the stoves of the House of Lords. It was the overheating of the flues by heaping on this fuel which occasioned the burning down of the old Houses of Parliament.

Charles Dickens once made the burning of the Houses of Parliament the subject of a humorous speech delivered before an Administrative Reform Association. He said "Ages ago, a savage mode of keeping accounts on notched sticks was introduced into the Court of Exchequer, and the accounts were kept much as Robinson Crusoe kept his calendar on the desert island. In the course of considerable revolutions of time . . . . a multitude of accountants, book-keepers, and actuaries were born and died. Still official routine inclined to these notched sticks

accounts continued to be kept on certain splints of elm-wood called tallies. In the reign of George III. an enquiry was made by some revolutionary spirit whether-pens, ink, and paper, slates and pencils being in existence-this obstinate adherence to an obsolete custom ought to be continued." And so the speaker proceeded to make fun of these "preposterous sticks" which were only abolished in 1826 , and then instead of being given as firewood to the miserable people of the neighbourhood, were used as fuel to overgorge a stove, and cause a devastating fire which necessitated the expenditure of a million of the public money to make good the loss. 
The national treasury was at Westminster. Close to the Chapter House of the Abbey is an ancient vaulted chamber, called the Chapel of the Pyx - so named from the box which contained the sacred wafer, though the term was afterwards given to the public trial made there of the weight of the coinage for currency. The once wellguarded entrance to this place, which was no less than the Treasury of England, is in the eastern cloister; it is an ancient double door which could never be opened except by the officers of the Government, or their representatives, bearing seven keys, some of them of large dimensions. Though access to the Chamber was purposely made a ponderous formality, in the time of Edward I. the chamber was forcibly entered and plundered of its contents.

The periodical attendance of the Sheriff at the Royal Treasury for the discharge of his onerous duties and responsibilities there, adds further variegation to the already composite pattern of his official life.

At each session of the Exchequer a president sat at the head of the chess board table-the king was the nominal president, but his place might be taken by the Justicier or other great official. On the right sat the Treasurer; the Chancellor sat on the left. Further to the left, but clear of the table, were the Constable, two Chamberlains, and the Marshal. The Chamberlain shared with the Treasurer the duty of receiving and paying money, and the keeping of an accurate account of the state of the treasury. The Marshal (a subordinate of the Constable, a high official, who was responsibile for the army) had the custody of all vouchers. 
These officers and their subordinates constituted the court of accounts, or upper exchequer-there was lower exchequer, or office of receipt and payment-where there was also an appointed calculator, who exhibited the state of each account by means of counters on the exchequer table, so that the proceedings of the court might be clear to the presumably illiterate Sheriff.

When Henry II. overhauled the Shrievalties he found the office frequently held by powerful barons who had grossly abused their authority, and whom he promptly removed; in many cases appointing in their places trained clerks of the Exchequer. The reform was evidently shortlived, as in the succeeding centuries the office was filled in all parts of the country by members of the baronage.

The political struggles of the reigns of Henry III., Edward I. and Edward II., amongst other results, transformed the Exchequer into a purely revenue department, a decision brought into effect by the Parliament of Lincoln, I3I6. Under the Angevin Kings both thesaurarial and judicial functions pertained to the Court of Exchequer, and besides the Treasurer there was also a Chief Justice, and another great officer, the Chancellor, who appears to have originally acted as the King's private secretary.

This Secretary obtained the name of Chancellor (Cancellarius) because he sat at a desk behind a lattice-work screen, the Latin name for which was cancelli. Or, according to Coke, he was so called from cancellendo, from " cancelling" the King's letters patent when granted contrary to law, which is the highest point of his jurisdiction. At first the Chancellor ranked as a very humble officer. He resided in the palace and had a daily allowance 
of " five shillings, a simnel, two seasoned simnels, one sextary of clear wine, one sextary of household wine, one large wax candle, and forty pieces of candle." The money allowance was made only if he dined out ; if he dined at home he got threeand-sixpence, with a slight variation in the other commodities. . . . He kept the King's seal and the King's conscience.

The independence of the financial department had become a great issue by I3I6. The Sheriff's duties were not confined to executing the behests of the courts of law, and attending the judges on circuit. The Sheriffs superintended the muster of the troops and were charged with the supply of men and munitions for public purposes. They conducted the parliamentary elections, paid the members, and controlled the sources of information as to the state of the country, then available to the government. And-a matter of great importance-the bulk of the royal revenues passed through their hands.

Among the legislative enactments of the Parliament which opened 28th January, I3I6, was a statute relating to the appointment of Sheriffs and Hundreders; and while those troublous times brought the repeal of some enactments at the Parliament of York in I322, the Statute of Sheriffs was carefully excepted, and the method of appointing those officers lasted till the Stuarts.

The Ordinance provided that Sheriffs were to be appointed by the Chancellor, and by the Treasurer and Barons of the Exchequer; or in the absence of the Chancellor, by the Treasurer, the Barons, and the Justices of the Bench, and that the commissions must be issued under the great seal. Thus the Chancellor had the power of putting his veto upon any appointment; which had not been so before. 
At the time of the Provisions of Oxford (1258) the Sheriffs were chosen by the King in Council, and were summoned to come to the Exchequer and receive the keepership of their counties in the form lately provided. At this date the Exchequer appears to have been on the Baron's side, and the Chancery on the King's. The Chancellor is forbidden to consider himself responsible to the King only. He is to seal no writs but on an order by the Council.

Although one of the Provisions of Oxford was intended to make the office of Sheriff an annual one, it did not become so until more than a century later. The choice of Sheriffs was always a point of no little importance during the political struggles of that century. Henry III's barons appointed one set, and the King another.

In 1389 the great scandals in the Exchequer involved an almost complete change of Sheriffs.

It has been asserted that during the thirteenth and first quarter of the fourteenth centuries any general change of Sheriffs was equivalent to a very rapid fall in the political barometer. From the advent of John de Clancy to the office of Treasurer in 1278 there was a desire and an effort made to maintain the system of getting grants of money to the Crown passed in the separate County Courts instead of having to appeal to the representative body of the whole country assembled in Parliament. But this system had gradually died out by 1295 .

The preamble to the Statute of Lincoln recites as the reason for the change in the system of appointing Sheriffs, the continual oppressions suffered by the people through the appointment of unsuitable men. 
The new Sheriffs were not to be merely the servants of the department primarily concerned with the collection of the revenue and the assertion of the King's rights as against the people-they must be landowners in their respective counties. As some holders of the office had been known to grow immensely rich, the motive for the change is not far to seek.

All this turmoil centring round the office of Sheriff is a tribute to its immense importance, and indicates the power, either for good or for evil, conferred upon the holder of it in those ruder times.

It is significant, also, of the spirit in which escheats to the Crown, and other accidental profits accruing to the Exchequer in those times, were levied by these official escheators, that we have derived the words " cheat" and "cheator" from the name of such legalised extortioners. 


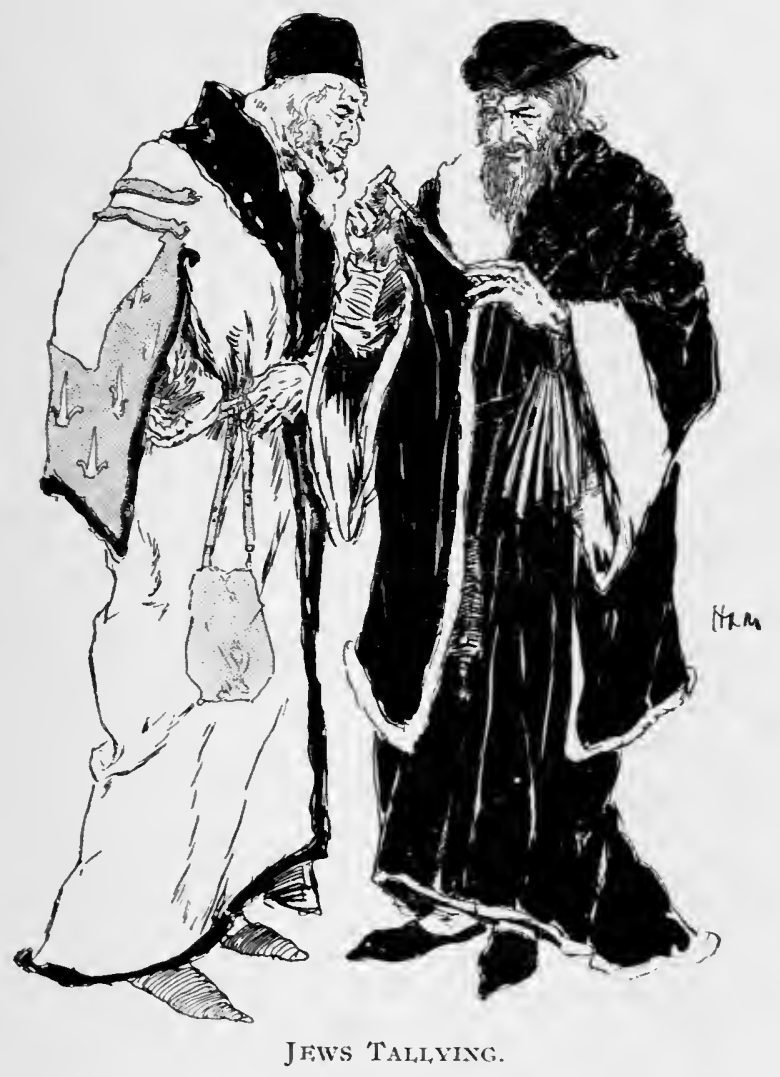





\section{$\mathrm{XV}$.}

\section{THE KNIGHTS OF THE SHIRE}

It has appeared there was a threefold object in dividing the realm into shires; namely, for the administration of justice; for the collection of revenue; and for the raising of a national army by territorial contingents. In all of these the Sheriff took the leading part; and later, when parliamentary representation by shires and lesser constituencies came into being, what official so readily available, what officer so competent to deal with the matter, as the Sheriff? And so when the time arrived, and circumstance demanded, the Sheriff became the Returning Officer of the County.

It is interesting to trace the connection between the High Court of Parliament and the ancient Shire and Hundred Courts ; between the national representative assembly and those embryonic local assemblies whose deliberations and decisions-judicial, perhaps, rather than legislativegave effect to the popular will and secured redress of popular grievances in more primitive times.

It is interesting to remember that before the Counties sent members to parliament in 1295, the Knights or lesser barons had met in their own counties for local government.

The function of the county in parliamentary representation began long before the era of the House of Commons. At the time when the Tribal English Kingdoms existed, each kingdom 
had its Folk-moot or assembly of the people, who held counsel with the King and his "wise men" on the affairs of the kingdom, and also formed a judicial court. After the heptarchy had passed away, the Folk-moot was continued in the united England as the Shire-moot, while for the affairs of the whole realm, a supreme Great Council sprang into existence. After the Norman Conquest the National Council underwent some changes, but the right of Englishmen to deliberate on national affairs, and to direct taxation, was steadfastly maintained.

From the Domesday inquiry a practice grew up of sending out Commissioners to consult with the local authorities of the Shire and Hundred Courts, on the administration of criminal justice, and the levying of national taxes. This was the first real attempt to keep the central government in touch with local representatives.

The bringing together, by Simon de Montfort, of the representative burgesses and shire men, first gave us all the elements of a modern parliament.

When the Sheriffs were required by Simon de Montfort to send two burgesses to represent each borough, a new class was added to the King's Council or national parliament.

In the Writs of 1254 the Knights of the Shire were summoned to appear " in the stead of each and all," the object of county representation being then purely financial. In I264 the towns were first admitted to representation, so that from the first the importance of the representative principle in matters of taxation, seems to have been tacitly admitted.

Writs were sent out to 37 counties and I66 burghs for the important parliament of I295; the 
number of the counties were fixed, although the king might alter the number of the enfranchised burghs.

The Knights of the Shire, coming in place of the lesser tenants-in-chief, were representative of the freemen of the county rather than of the feudal class; and though they really belonged to the baronial class, as representative of the countryfolk, they identified themselves with the representatives of the towns, and elected to sit in the same chamber with them-the House of Commons. While the lords of parliament were summoned personally, the elected representatives were always summoned through the Sheriff.

In I7ro (9 Anne c. 5) it was enacted that no person should be returned to Parliament as a Knight of the Shire who had not a landed estate worth $£ 600$ a year.

The Sheriff, as returning officer at parliamentary elections, does not boast an altogether impeccable record. Hallam records six instances during the Plantagenet period, wherein the misconduct or mistake of the sheriff called for specific animadversion; indeed the laxity of the sheriffs at elections was frequently the ground of general complaint, and even of some statutes. For instance in I2 Edward II., a petition was presented to the Council against a false return for the county of Devon; and in 36 Edward III., the sheriff of Lancashire was found in fault, when the wages for attendance at Parliament were claimed by knights of the shire unduly returned by him as having been elected. Defaulting sheriffs were usually summoned before the Court of Exchequer to answer for such delinquencies.

It appears that at the voting for members of parliament in the county courts of that period, the 
privilege of the franchise was notlimited to tenantsin-capite, but was based on a much broader foundation ; for not only all freeholders, but all persons whatsoever present at the county court, were declared or rendered capable of voting for the Knight of the Shire- a more democratical basis of the representative principle than is commonly supposed. It was a retrograde measure in the reign of Henry V. (I429) which disqualified men of small estate from voting, limiting the county electorate to freeholders with estates of and above the annual value of $40 \mathrm{~s}$.

Before the year I429 a sort of universal suffrage appears to have prevailed. An act ( 8 Henry $V$.) was then passed to put an end to this prematurely democratic state of things, and set up a property qualification. After reciting that " the elections of knights of shires in many counties had then of late been made by very great and excessive number of people dwelling within the same counties of which most part was a people of small substance and of no value, whereof every one of them pretended a vorce equivalent with the most worthy knight and esquires dwelling within the same counties, whereby manslaughters, riots, batteries, and divisions among the gentlemen and other people of the same counties would very likely rise and be, unless convenient and due remedy were provided," the Statute enacts, " That the Knights of the Shires shall be chosen in every county by people dwelling and resident in the same counties, whereof every one shall have free Land or Tenement to the value of Forty Shillings by the year at the least, above all charges."

This was the origin of the "Forty Shilling Freeholder." By Io Henry VI., c. 2 the qualification must be situate or arise within the County 
for which the Freeholders claimed to vote; a condition which was not formally expressed in the previous Statute.

The qualifying figure of five hundred years ago was estimated by Bishop Fleetwood to have been equal to $£^{\mathrm{I} 2}$ per annum in Queen Anne's days, and by Blackstone as equivalent to $£ 20$, which is the more correct. The permanence of the qualification for the County franchise is thoroughly English.

The forty-shilling freeholders tended to make the House of Commons less representative, because this franchise was really a restrictive one; and besides, the elections were really controlled by the large land-owners. One of the first steps in constitutional government, introduced by Henry IV. was to forbid Sheriffs interfering in elections.

The Sheriffs were also at that period the returning officers for the cities and boroughs. The kings who first summoned parliaments-little foreseeing the lofty prerogatives to which the then half-emancipated burghers would eventually attain - could but address the Writs of Summons for the towns, as well as for the counties, to the same officer. Thus the writ of 23 Edward.I. directs the sheriffs to cause deputies to be elected to " a general council" from every city, borough, and trading town. The latter phrase, though subsequently omitted from writs, gave the sheriffs such discretionary power that quite a number of "trading towns," which were not chartered boroughs, and had no other claim than that of populousness, or commerce, became in course of time boroughs of prescription. Some " considerable places," though unincorporated, but which could afford to defray the expenses of a representative, took such a notable interest in the public 
welfare, that they regularly exercised the franchise and elected two " burgesses" to successive parliaments-and from this cause alone many towns came to be called boroughs, though they held no charter, either from the crown or from mesne lord. The point here, however, is that the Writs of Summons were at first addressed in general terms to the Sheriff, and it therefore rested really with him to determine what towns should exercise the elective franchise.

Not a few towns willingly forewent the privilege of parliamentary representation rather than pay a representative. From I349 to I547, for nearly two centuries, no Lancashire borough sent members to parliament, and the county was represented only by the knights of the shire. One Sheriff of Lancashire returned " there were no cities or boroughs in his county that ought, or were used, or could on account of their poverty, send any citizens or burgesses to Parliament." The average payment was four shillings a day for a Knight of the Shire and two shillings for a citizen or burgess, levied on the constituency.

There was a custom of girding with a sword each Knight of the Shire upon his election; a custom honoured in the metropolitan county by its breach, probably because the parliaments were usually held in Middlesex, the Knights whereof had only fees for their attendance, and no allowance for travelling, as in other shires. The practice appears to have disappeared altogether after I769, so far as Middlesex is concerned, when Wilkes was being repeatedly re-elected for that constituency.

On the subject of " Knights of the Shire," William Somner, the seventeenth century antiquary and learned compiler of an Anglo-Saxon 
Dictionary, has an interesting note. According to this authority the Anglo-Saxon form of the word " Knight" was "Cniht," and it meant " a boy, a little boy or child, a young youth or stripling, also a servant, a servitor, a man-servant. Indeed, the word, properly interpreted beside that of a boy or youth, signifies no more than a servant. Witnesse that use of it yet remaining in our ' knights of the shire,'-which, although no knights by dignity or place, yet are so calledbut why? Under favour, in regard of that service which is required and performed of them in Parliament for their several counties, whose servant for the time they are."

This certainly rather discounts the dignity of county representation; but, be it remembered, it was a strained definition, written during the levelling days of the Cromwellian Commonwealth.

Till the Reform Act of I832 all the forty English counties had returned to Parliament " two knights of the shire" each-except Yorkshire, which since I82I had been allowed to return four; thirty-seven of them continuously from the time of Edward I., Cheshire and Monmouth from the time of Henry VIII, and Durham from the days of Charles II.

The "reform" of 1832 (among other things) divided the following twenty-five counties into two electoral districts each : Cheshire, Cornwall, Cumberland, Derbyshire, Devonshire, Durham, Essex, Gloucestershire, Hampshire, Kent, Lancashire, Leicestershire, Norfolk, Northamptonshire, Northumberland, Nottinghamshire, Shropshire, Simersetshire, Staffordshire, Suffolk, Surrey. Sussex, Warwickshire, Wiltshire and Worcestershire. 
Seven others were not divided, but were allotted an additional member each; namely, Berkshire Buckinghamshire, Cambridgeshire, Dorsetshire, Herefordshire, Hertfordshire, and Oxfordshire.

In the case of seven others, where apparently there was insufficient increase of population to call for additional representation, no change was made; these were Bedfordshire, Huntingdonshire Lincolnshire, Middlesex, Rutland, Westmoreland, and Monmouthshire.

Nor was any alteration made in the representation of the twelve Welsh counties, represented by one member each from the time of Henry VIIr, namely Anglesey, Brecknockshire, Cardiganshire, Carmarthenshire, Carnarvonshire, Denbighshire, Flintshire, Glamorganshire, Merionethshire, Montgomeryshire, Pembrokeshire, and Radnorshire.

Before the passing of the 1832 Reform Bill, of $55^{8}$ members of Parliament for Great Britain, about half represented constituencies south of a line drawn from Gloucester to Harwich. Cornwall, for instance, had 40 members, nearly as many as Yorkshire and Lancashire together. The northern counties had not yet come into their own - mining and manufacturing had not yet ousted agriculture from its ancient eminence.

The Scotch counties represented in the British Parliament by one member each, from the time of the Union under Anne, were then thirty in number : Aberdeen, Argyle, Ayr, Banff, Berwick, Dumbarton, Dumfries, Edinburgh, Elgin, Fife, Forfar, Haddington, Inverness, Kincardine, Kirkcudbright, Lanark, Linlithgow, Orkney and Shetland, Peebles, Perth, Renfrew, Ross, Roxburgh, Selkirk, Stirling, Sutherland, Wigton, Bute and Caithness alternately, Clackmannan and Kinross alternately, Cromarthy and Nairn alternately. 
Of Irish counties represented in the Imperial Parliament by two members each, from the Union under George III, in I80I, the following is an alphabetical list : Antrim, Armagh, Carlow, Cavan, Clare, Cork, Donegal, Down, Dublin, Fermanagh, Galway, Kerry, Kildare, Kilkenny, King's County, Leitrim, Limerick, Londonderry, Longford, Louth, Mayo, Meath, Monaghan, Queen's County, Roscommon, Sligo, Tipperary, Tyrone, Waterford, Westmeath, Wexford, and Wicklow.

Of the changes, re-groupings, and subdivisions made by subsequent Redistribution Acts it is unnecessary to treat here.

There occurs in Fraser's Magazine for November, I837, a political song, entitled "The Counties," which reviews, county by county, the result of the general election then recently over; the nature of this effusion may be judged from the following sample of its quality-_

Here's to the counties divided in two, Here's to the undivided at all, sir !

Here's to the Shires with one member ! though few Have an allowance so small, sir. Melbourne's vile crew Well may look blue

While they are reading the county list through.

Down to I888 the fifty-two geographical counties had each one Sheriff, even if it were divided into Parts (as Ridings) that had each a distinct county administration; although within such counties there were not a few places exempt from the jurisdiction of the County Sheriff, and entitled to have Sheriffs or equivalent officers of their own-as the " Counties corporate," or those cities and boroughs which were " counties in themselves." 


\section{XVI \\ THE HIGH SHERIFF}

The High Sheriff is still the chief civil officer of the county, holding the office for one year only, to which he is appointed with the same quaint old formalities which have been observed for centuries.

The story of the shires is to a very considerable extent the history of the evolution of the office of Sheriff. Established in Saxon times with almost vice-regal powers, the Sheriff's office was utilised to constitute a local constitutional authority representative of several departments of the state ; but as the shrieval machinery grew out of date, the office was gradually shorn of much of its ancient importance.

The election of the Sheriffs of London and Middlesex was granted to the citizens of London for ever, in very ancient times, upon condition of their paying $£ 300$ a year to the King's exchequer. In consequence of this grant, they elected two Sheriffs, though these constituted together one officer. In I748 a bye-law of the city imposed a fine of $£ 600$ on every person who, being elected, refused, to serve the office of sheriff.

The High Sheriffs of the counties of England and Wales (except Cornwall and Lancashire) are nominated every year on the morrow of St. Martin (November 12). The Chancellor, Chancellor of the Exchequer, the judges, and several of the privy councillors, assemble at the Law Courts; 
an officer of the court administers an oath to them in old French, that they will nominate no one from favour, partiality, or any improper motive. The same officer produces a list of the counties in alphabetical order, and of those who were nominated the year before, reads out three names to each county, and the last of the three he pronounces to be the present Sheriff. But where there has been a " pocket sheriff"- - one not of the three nominated by the judges in the exchequer, but who has been appointed directly by the king, of his royal prerogative-he reads the three names upon the list, and then declares who is the present sheriff. Should any of the ministry or judges object to a person named in the list another gentleman must be named in his room. If no objection be made, some one rises and says, "To the two gentlemen I know no objection, and I recommend $\mathrm{A} \ldots \ldots . . \mathrm{B} . . . \ldots \ldots$. Esq., in the room of the present sheriff."

This ancient and interesting ceremony, which dates to the reign of Edward II, and popularly known as "pricking the sheriffs," is but the nomination of three gentlemen, fitted by wealth and position in each county in England and Wales (excepting the Duchies of Lancaster and Cornwall) to occupy the position of High Sheriff. The " pricking" is really done in the February ensuing by His Majesty the King, who with a golden bodkin, "pricks" the name of one of three gentlemen named for each county, almost invariably that of the first on the list placed before him.

The popular election of Sheriffs was terminated in the reign of Edward II; and the office is now not only gratuitous but compulsory. For Cornwall the Sheriff is nominated by the Prince of 
Wales as Duke of Cornwall, while for Lancashire the Sheriff is appointed by His Majesty, as Duke of Lancaster.

The ceremony even in its most modern form, recalls the ancient Exchequer wherein the Sheriffs were the connecting link between the Shire-moot and the Curia. Not only are the judges summoned for this appointment, but all the members of the Cabinet. 'The justiciarii and Great Officers of State sit once more on the Exchequer side of the Curia, only the Exchequer and his Barons are now gone, and the Chancellor of the Exchequer finds himself presiding once a year in the King's Bench Division of the High Court of Justice. On such occasions he wears a gorgeous robe of black silk, with costly and elaborate gold embroidery-a robe which his predecessors in former days wore as Judges of the Court of Exchequer, and which is still distinctive of his high office.

The right of the sovereign to name whom he pleases to be sheriff, whether chosen of the judges or not, was grounded on a particular case in the fifth year of Queen Elizabeth, when by reason of the plague, there was no Michælmas term kept at Westminster, so that the judges could not meet to go through customary forms of nomination ; whereupon the queen named them herself without any such assembly. Though this was the only authority for making these extraordinary sheriffs, a procedure whereby the royal prerogative was set above the laws, the practice of occasionally naming the so-called " pocket sheriffs" continued till the time of George III.

The new Sheriff is generally appointed about the end of the following Hilary term which enables the old sheriff to hold officer over the Michaelmas and Hilary terms. By several old statutes it is 
required that no man shall continue in the office longer than one year, and by a statute of Richard II. no man who has served the office of sheriff for one year can be compelled to serve the same again within three years after.

Not unfrequently a person nominated has raised objection himself, pleading sometimes that he is likely to be abroad; or that he is a practising barrister or else a military officer; or that his estate is small and that he has no equipage; and so on.

The Council takes into consideration the validity of the excuses and, if necessary, hears the evidence of counsel on the matter, and if the excuses be eventually accepted it then becomes the duty of the judges who went on circuit in the district at the last summer assizes to name other gentlemen to take the place of those excused. For this purpose their lordships have provided themselves with lists of the names of suitable persons, from which, when the King's Remembrancer calls out, " One name wanted," or " Two or three names wanted," as the case may be, they read as many as required. And thus the list of shrieval appointments is satisfactorily made up.

In the county of Rutland, the area of which is so very small, there was so often a difficulty in finding a man of the usual high social station for this office, that it became customary there to draw regularly upon the farming class for this purpose. Huntingdonshire is joined with Cambridgeshire in the appointment of a sheriff to serve both counties, and in the middle ages one sheriff long served for the two counties of Norfolk and Suffolk, a practice reminiscent of their original status as the Kingdom of East Anglia. 
If country gentlemen came at last to be chary of accepting this ancient and honourable office, it was not because its dignity had declined, so much as on account of the gross extortions to which the holders of it were subjected by a crowd of official hangers-on, who existed merely for the maintenance of an antiquated and useless ceremonial of state. So a time came when sheriffs of strong mind and sound common sense dispensed with much of the old ceremonial; one went to meet the judges in a hired carriage in lieu of the traditional golden coach; another cut off the trumpeters ; and a third suppressed the javelin men, till, in some county-towns, the ancient pageantry of the judicial procession had all but disappeared.

To the Sheriff was committed the care of an undischarged jury, whom the judge possessed the power to lock up without meat, drink, fire or candle, until they had agreed on their verdict. And if the judge was obliged to remove to the next Assize town on his circuit before the jury had found their verdict, the Sheriff had to take the jury after him in a cart.

Some years ago a "little bill" of the charges in which a High Sheriff had been mulcted was communicated to The Times. It appeared that, in the course of three assizes in one single county, the gentleman whose duty it was to entertain the judges of the land, was called upon to pay the piper at the following prodigious rate,-Item. For the Judges servants, $£ 8$, I8s. 6d. ; and for ale for them, $£ 9$ Igs. The " ringers" cost three guineas, which must be considered as cheap at the price, seeing that no extra charge is made for being deafened or driven half crazy by the intolerable clangour of the bells. The " use of the pulpit" was charged at one guinea; but we are not told 
whether this included the use of a clergyman, a beadle, and a pew-opener. The "trumpeters" had $£ 58 \mathrm{~s}$. between them; and though this seems in all conscience sufficient for the duties they had to perform, they further shared, with the "clerk of assize" and the " chaplain," in the sum of eleven pounds charged for wine. Then a mysterious individual, alluded to as $\mathrm{Mr}$. P.charged $f$ Io I6s. Iod. for attending at the Treasury, passing the accounts, and obtaining the Sheriff's quietus! And so the items ran on in a range of conscienceless extortions.

Some times a judge on circuit travels with a marshal, a clerk, a butler, a cook, a valet, and a marshal's man, and at times the cook carries his own cooking utensils, so that the baggage of the whole retinue is enormous. At a West Country Assize town the judge's lodging contains fourteen bedrooms.

The Sheriff, as principal county officer, still has to perform certain functions in connection with the administration of justice.

The chief of his personal duties is obligatory; he must attend personally and in proper state upon His Majesty's Judges when they come to hold the Assizes for his county; the sufficient lodging and maintenance of them during that period is also laid to his charge.

The accommodation to be provided always includes fire, lighting, linen, table equipment, kitchenmaids, scullery-maids, chambermaids, and not infrequently a staff of men-servants ; to say nothing of the time-honoured responsibility for providing the judge's state coach, having the church bells rung on his lordship's arrival, and engaging the trumpeters to grace his presence. 
The High Sheriff who neglects to be in attendance on the Judge of Assize is liable to a heavy penalty. At the Winchester Winter Assizes of I892 the High Sheriff of Hants was fined 500 guineas for not being present. He had utterly forgotten that he was High Sheriff and had gone away on a health cruise to Africa.

His ancient presidency of the County Court, and the other common law duty of commanding and controlling the militia, have long since disappeared. As chief ministerial officer of the Superior Courts of Justice, the Sheriff executes (vicariously, of course) all processes issuing therefrom; in civil cases serving writs and taking bail ; in criminal causes arresting and imprisoning, summoning the jury, keeping custody of the delinquent, and executing sentence upon him. He has to carry out the law even to the extreme penalty, for there is no official hangman.

In the time of Edward IV. when the King's officers attempted to set up their own scaffold and gallows on Tower Hill, the city of London resisted, and the Sheriffs successfully maintained their right to carry out all executions-revolting and cruel as some of the accompaniments were.

Yet this part of a Sheriff's duty had its risks in bygone days when the deadly typhus was commonly present under the name of " gaol fever." In I577, at the Black Assize at Oxford, there died of the gaol fever two judges, the sheriff of the county, two knights, several justices of the peace, and all the jurymen but one.

A Sheriff may not " hold pleas of the crown," that is, try criminals; for it would be altogether unbecoming for one to be both judge and executioner, or even to impose a fine and then to levy it. Indeed, during the year of his shrievalty 
he may not act as a magistrate, as this would be equally inconsistent.

Formerly the Sheriff exercised both civil and criminal jurisdiction; the former in the Sheriff's County Court, and criminal jurisdiction in the Sheriff's Tourn or Turn-the Tourn deriving its name originally from the Sheriff's taking a "turn " or circuit about his shire and holding this court in several places. The Tourn was a court of record, having jurisdiction in claims of 40 shillings and upwards; it was finally abolished in I877. The Sheriff's County Court was not a court of record, the claims for debt or damage exceeding 40 shillings, or action for trespass, could not be tried there; the Sheriff's County Court ceased when the modern County Court was instituted in I846-the newer one is a statutory court having nothing to do with the ancient court it superseded.

The office of High Sheriff has grealty shrunk in importance since the days when he was " governor of the shire, president of its court, and captain of the forces."

As a judicial officer he had the administration of justice in the county court, and as a ministerial officer he was charged with the execution of all legal processes, civil and criminal.

The High Sheriff always appoints for his year of office a professional Under Sheriff, who is a trained lawyer. Then there are quite a number of underlings whose services are utilised to carry out the various duties pertaining to the office; as High Bailiffs of Hundreds and of other liberties, bound-bailiffs (" bum-bailiffs" who levy distress), foot-bailiffs, and other executive deputies, which occasion may require to carry out the processes of the law. For all these the High Sheriff is 
responsible, by virtue of his office. The Sheriff himself is considered as the bailiff to the crownthe word bailiff being of Anglo-Saxon origin, and signifying a keeper or protector. Of High Constables, Head Constables and similar executive officers of olden times it is not necessary to say anything here, as their functions have been largely merged in to those of the county police.

The Under Sheriff holds the courts necessary to carry out some of the judicial functions still pertaining to the office of Sheriff. On receipt of certain Writs, as a Writ of execution against one not able to satisfy claims for debt or damages, or a writ of enquiry as to damages, the Sheriff must summon a jury to inquire into and deal with the matterall of which is done through the Under Sheriff. The judicial functions of this official are pointed to in the old seventeenth century rhyme-

Swearers are lyers, lyers most are thieves,

Or God helpe jaylors and true under-shrieves.

As royal bailiff it would fall to the High Sheriff to collect crown rents, seize lands forfeited or escheated to the crown, and to take charge of wrecks, waifs, and strays.

The writs of parliament for the county being addressed to him, he controls the election of county members, making all necessary returns relating thereto; also elections for Coroners, when they occur, are in his hands.

As elsewhere shown, the ancient military functions of the office passed to the Lord Lieutenants. Yet to-day any male above sixteen years of age who refuses to obey the High Sheriff's call to withstand the King's foes is guilty of felony.

At one time posts were set up at the doors of Sheriffs on which the royal proclamations were 
fixed ; and it was the custom when a man went up to the Sheriff's posts to read the proclamation, to remain uncovered while doing so. In Newcastleon-Tyne and one or two other ancient " counties of cities" the compliment is still paid to the Sheriff of fixing two ornate lamp-posts outside the door of his private residence. 


\section{XVII}

\section{THE ASSIZES AND THE COUNTY TOWNS}

The capital of any country or province is the town which is the seat of the Government. Similarly the county-town is the one in which the Assizes for the county are usually held, and in which the other branches of local self-government for the shire area are carried on.

The country is divided into what are known as circuits, and in each circuit is a number of towns where Assizes are held. These towns are visited periodically, about three times a year, by judges of the High Court of Justice. Generally two judges go on circuit together, taking alternately the criminal and the civil business at the towns where the Assizes are held.

Because the judges come as the representatives of the sovereign to deliver the gaols of those charged with crime and to do justice among the people generally, a certain amount of state and ceremony is observed on these occasions, as the history of the Sheriff's office has disclosed. The county authorities have to provide " Judges' Lodgings," that is, suitable accommodation in which the monarch's representatives may reside during the Assizes. On their arrival, of which due notice is officially communicated to those concerned, the royal judges are met by the High Sheriff, as the leading county official annually appointed by the Crown. 



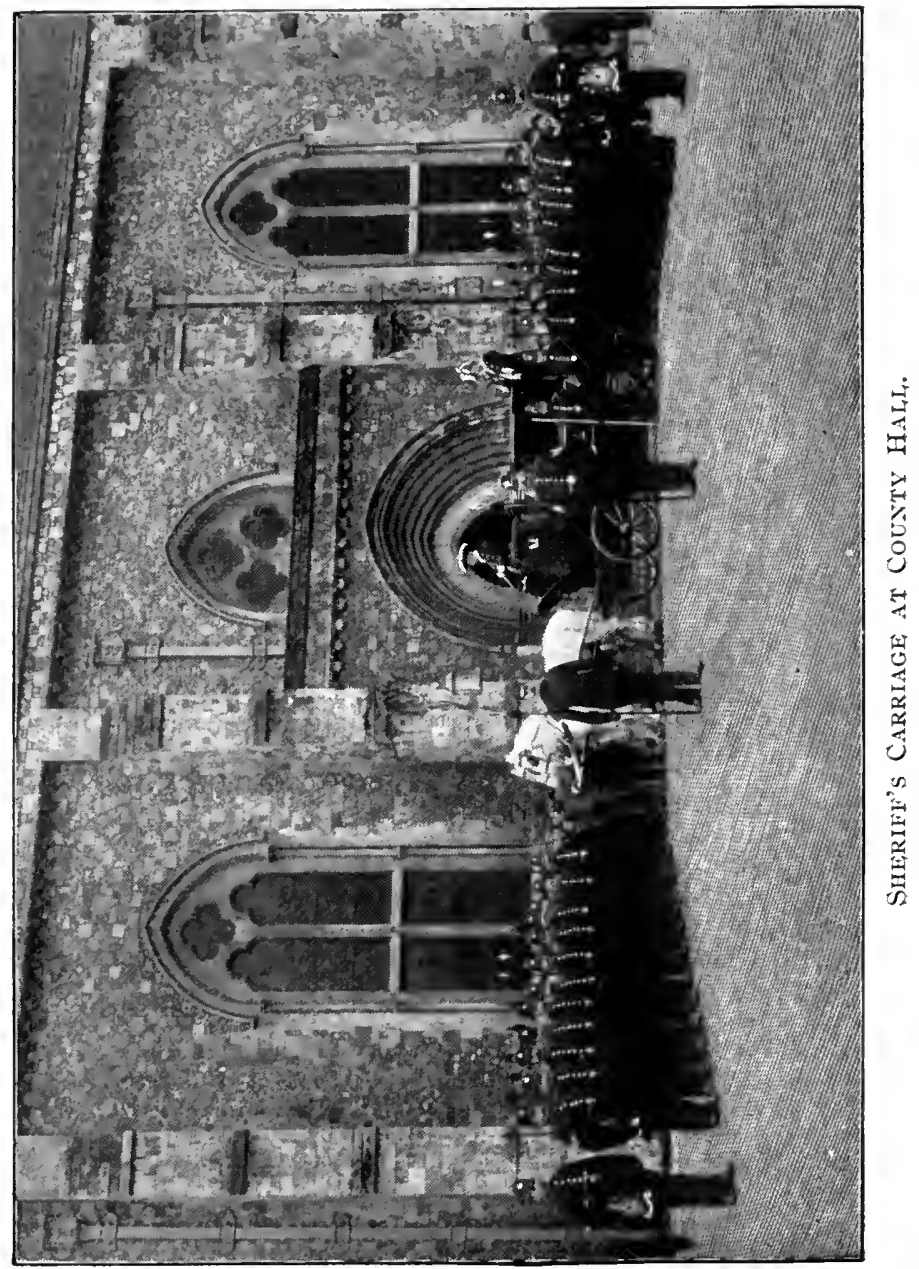


The time-honoured practice is to meet them with a state carriage drawn by two or four horses, and sometimes by outriders, the coachman and footmen invariably rejoicing in powdered wigs and gorgeous liveries. The Sheriff himself wears either court dress with a sword, or, if he is an officer in any branch of his majesty's forces, a military uniform. The escort to the Assize Courts often includes besides trumpeters, marshals, javelin men, and other attendants; and the commission is opened in the criminal court by the reading of the royal proclamation.

The business of the Assizes begins next morning. The Court in which criminal trials take place is known as the Crown Court (because proceedings are undertaken in the name of the Sovereign). where the bewigged judge wears a robe of scarlet trimmed with ermine; his colleague donning a black robe and a wig presides in the civil court. The latter is sometimes called the Nisi Prius Court, because formerly all county causes were ordered to be tried on a given day " unless before" the judges came into the county to which the cause belonged.

Henry II. divided the country into six circuits or districts with three judges assigned to each, for the administration of the King's justice. This was done in II76 at the Council of Northampton, thus effecting a much needed reform by which each division of the Kingdom could be periodically visited by justiciarii itinerantes, or "justices in eyre."

Justices in Itinere (or " in Eyre ") were intended, not merely to improve the administration of justice, but particularly to remove the great inconvenience arising from the high court of law following the king's person. At first the judges 
passed round the kingdom once a year, commissioned to hold their Assizes in the various places appointed for the sittings.

Assizes united indissolubly the royal and the popular elements of justice, and replaced judicial combat by something which approaches very near to trial by jury; more than that, they encouraged the principle of selective representation, and revived and re-organised the national militia.

All this business was in the hands of the Sheriffs, and it is significant that in II70 a clean sweep had to be made of corrupt local Sheriffs, when officials royally nominated were everywhere substituted for them.

One of the most important changes made by Magna Charta was a provision restraining Assizes to their respective shires, so as to save the unfortunate suitor from following the Curia Regis from one end of the kingdom to the other, as had been the case during King John's itineraries. But this provision was so far modified as to enable Justices Itinerant to adjourn suits to another day and place in the same circuit; and with this result, that the ancient pleas of one county are not infrequently to be found on the plea rolls of some adjacent county.

The old circuits prior to 1830 were (I) The Home Circuit consisting of the counties of Hertford, Essex, Kent, Sussex and Surrey; (2)The Midland Circuit, consisting of the counties of Warwick, Leicester, Derby, Nottingham, Lincoln, Rutland and Northampton; (3) The Norfolk Circuit consisting of the counties of Norfolk, Suffolk, Cambridge, Huntingdon, Bedford, and Buckingham; (4) The Northern Circuit, consisting of the counties of York, Northumberland, Cumberland, Westmoreland, Lancaster, and Durham ; (5) The Oxford 
Circuit consisting of the counties of Oxford, Worcester, Stafford, Salop, Hereford, Monmouth, Gloucester, and Berkshire; (6) The Western Circuit consisting of the counties of Hampshire, Wiltshire, Dorset, Devon, Cornwall, and Somerset.

To these were added in I83I the two Welsh Circuits; and three years later it was provided that assizes might be held at more than one place in the same county-in Yorkshire, for instance, in each of the three Ridings.

Other alterations were made from time to time. In I863 the county of York was taken out of the Northern Circuit and annexed to the Midland Circuit; then the counties of Leicester, Rutland, and Northampton were taken out of the Midland Circuit and annexed to the Norfolk Circuit. Later, the public convenience was sought by making it possible to discharge the civil and criminal business of Surrey through judges and juries trying issues in Middlesex and London.

By the Winter Assizes Act 1876 certain counties were united to facilitate the more speedy trial of prisoners.

There are now eight of these circuits, each containing from six to nine towns. They are the Northern and North-Eastern, the Midland, the Oxford, the Western, the South-Eastern, the North Wales and the South Wales.

The Northern Circuit covers the counties of Cumberland, Westmoreland, and the County Palatine of Lancaster; the towns visited by the judges being Carlisle, Appleby, Lancaster, Manchester, and Liverpool.

The North-Eastern Circuit covers Northumberland, Durham, and Yorkshire; the towns visited being Newcastle, Durham, York and Leeds. 
The Midland Circuit covers the counties of Lincoln, Nottingham, Derby, Warwick, Leicester, Northants, Rutland, Bucks and Beds. ; the assizes being held at Lincoln, Nottingham, Derby, Warwick, Leıcester, Northampton, Oakham, Aylesbury, and Bedford and Birmingham.

The Oxford Circuit covers the counties of Oxon, Berks, Worcester, Stafford, Salop, Hereford, Monmouth, and Gloucester; the towns visited by the judges being Oxford, Reading, Worcester, Stafford, Shrewsbury, Hereford, Monmouth, and Gloucester.

The Western Circuit takes in the counties of Hants, Wilts, Dorset, Devon, Somerset, and Cornwall ; the towns visited including Winchester, Salisbury (or Devizes), Dorchester, Exeter, Taunton, Bodmin and Bristol.

The South-Eastern Circuit includes the counties of Norfolk, Suffolk, Hants, Cambs, Herts, Essex, Kent, Sussex and Surrey; the towns at which Assizes are held include Norwich, Ipswich, Huntingdon, Cambridge, Hertford, Chelmsford, Maidstone, Lewes, and Guildford.

In the North Wales Circuit are included the assize towns of Chester, Mold for Flintshire, Ruthin for Denbighshire, Carnarvon for the county of that name, Beaumaris for Anglesey, Welshpool for Montgomeryshire, and Dolgelly for Merionethshire.

In the South Wales Circuit the towns visited are Haverfordwest for Pembrokeshire, Lampeter for Cardiganshire, Carmarthen for the county of that name, Brecon for Brecknockshire, Presteign for Radnorshire, and Cardiff or Swansea in Glamorganshire.

London and Middlesex, as previously mentioned, are not comprised in any circuit, but courts for 
the trial of issues by a jury are held before judges of the High Court four times every year at what are called the London and Middlesex sittings.

In I834 the Central Criminal Court was instituted to deal with London, Middlesex, and certain of the metropolitan suburbs which reached into Essex, Surrey, and Kent. The county-town of Middlesex was Brentford so far as the holding of assizes and the county election in olden times could make it so. The Essex Assizes were at one time holden at Brentwood. In Northumberland the Assizes were formerly held at Alnwick till the large centre of population claimed the privilege. In Lancashire Preston claims to be of more importance, and certainly more central than the old county-town ; it is the headquarters of the county police and the meeting place of the County Council.

In recent years new towns which have become great centres of population-as Leeds and Birmingham-have been created Assize-towns; so that in one geographical county there may now be found more than one town enjoying that privilege which was once the special prerogative and characteristic of a county-town.

Although all the circuits now get three assizes a year, every assize town is not visited that number of times-density of population, and the demands for judicial attention necessarily arising therefrom, giving a new assize town like Leeds the full number, while an ancient county-town situated in a sparsely populated district, as Appleby is, has but two assizes each year. Formerly there might be four Assizes a year.

By the latest arrangement the dates of the Assizes in the eight Circuits are respectively about the middle of January (Winter) middle of May 
(Summer) and middle of October (Autumn). Except in Lancashire, Glamorganshire, Devon, Bristol, Suffolk, and Sussex, the Autumn Assize is for criminal business only. There is an additional assize, for Lancashire and Yorkshire only, in May.

In the winter and summer two judges are usually assigned to each circuit, except the Welsh circuits, to each of which only one is sent, the judges of the two Welsh circuits meeting and sitting together in the counties of Cheshire and Glamorgan. In the autumn the arrangements are irregular.

From time to time various groupings have been tried. In I876 power was given to the Crown, by an order in council, to unite certain counties for the holding of the Winter Assizes ; and in 1879 similar power was given for consolidating the business of several counties at the Spring Assizes. This system of grouping was found to be attended with great inconvenience to litigants, witnesses and others, who were kept waiting at long distances from their homes.

In I897 a scheme was promulgated for holding full Summer and Winter Assizes in all circuits; for an Autumn circuit in which only criminal business could be taken, except in Manchester, Liverpool, Leeds, and Swansea, where civil cases might also be tried; and for an Eastern Circuit for both kinds of business in Manchester and Liverpool, and criminal in Leeds. A later amendment of the schedule gave an Autumn Assize to Birmingham.

Since I878 the Crown has been einpowered to deprive any county of the privilege of having assizes held within it. To some of the smaller county towns which very largely depend upon 
the Assizes for their importance, the loss of this ancient privilege would mean a very substantial depreciation in their property values; little wonder, therefore, that the prospect of such deprivation fills them with dismay. Even a busy town like Stafford demurs to be superseded by Birmingham.

In Kent, Assizes were formerly held at East Greenwich, Dartford, Milton-next-Gravesend, Sevenoaks, Rochester, Maidstone, and Canterbury. In the time of Richard II. the assizes were held most frequently at Canterbury, and it was one of the grievances of Jack Cade and his followers that they had to travel from the farthest parts of West Kent into the east to attend the sessions of the peace " causing men some five days' journey, and they desired for the better administration of justice it should be divided into two parts."

Maidstone, once but of little repute, became the assize town after the Restoration. Canterbury (a county in itself) is, of course, the ecclesiastical capital of Kent, and Maidstone is now the county town. The cathedral city prefers that Maidstone should enjoy the privilege of carrying out executions.

The other corner county, Cornwall, also hesitates between its cathedral town, Truro, and Bodmin with its gaol, as to which is really the county town. Launceston was the ancient capital of the Duchy-the office of Constable of Launceston Castle is still in existence.

Maiden Assize is the name given to one in which no criminal is brought to trial; formerly when the laws were more draconian and bloodthirsty, the name applied when no criminal was left for execution. Such naturally occurred more frequently in the less populated counties, as in 
Anglesey, Monmouth, and Montgomery. There was a custom on such occasions to present the judge with a pair of white gloves, and the judge's attendants in some counties (as Yorkshire, where the occasions were extremely rare) claimed glove money till these fees were abolished some fifty or sixty years ago.

The giving of white gloves at a maiden assize is a piece of symbolism of Teutonic origin. Not only was the practice observed when no criminal had been called upon to plead- " called upon by name to hold up his hand "-but prior to the seventeenth century such prisoners as had received pardon after condemnation were accustomed to present gloves to the judges.

Those pardoned men who taste their prince's loves, As wedded to new life, do give you gloves.

In olden times when a sentence of outlawry was reversed, the culprit attended the court personally and presented gloves to the judges.

The judges do not sit in virtue of their position as judges of the High Court of Justice, but as commissioners specially sent down; and the arrangement is such that there is a General "Gaol Delivery "- that is, a clearance of prisoners awaiting trial, at least three times a year. 


\section{XVIII}

\section{THE LORD LIEUTENANT OF THE COUNTY}

The Lord Lieutenant was a military officer first appointed (it is believed) under Henry VIII., to preserve order in his county; and as such he succeeded to the powers and duties of Sheriffs and Justices of the Peace, as well as those of special Commissioners of Array. Under succeeding Tudor sovereigns, the office grew into permanence, and appointments thereto remain in the hands of the crown.

Another ancient office, though quite distinct, is usually joined with the Lord Lieutenancy - that of Custos Rotulorum. The duties of this office are to keep the county records (as the records of Sessions) and involve the appointment of the Clerk of the Peace, and the power of recommending to the Great Seal the names of fit and proper persons to be inserted in the Commission of the Peace for the county. The Lord Lieutenant is at the head of the county magistracy.

Though the Lord Lieutenant now heads the county organisations, his office cannot compare in antiquity with that of Sheriff. In the matter of precedency too, the Sheriff claims to come before the Lord Lieutenant, and an instance is recorded of a duke who had been Lord Lieutenant forty years, apologising to the Sheriff for having inadvertently taken precedence of him.

The office of Sheriff is of far more ancient foundation than that of Lord Lieutenant, which 
(according to Strype) was first established in the third year of Edward VI. to suppress the " routs and uproars " then active in most of the counties, during the religious ferment of the early stages of the Reformation. It might be supposed the sheriffs already possessed sufficient power for that purpose; but the means then adopted to restore tranquillity were not well calculated to be popular among the people-among the extraordinary measures taken at that time it was ordered that no drum was to be struck or pipe sounded; all plays were forbidden; and in the churches of Devonshire and Cornwall, Lord Russell was to take down every bell in a steeple save one, so as to prevent a peal being rung. The times were certainly out of joint when Lord Lieutenants were first called into being. They seem, on the face of it, to have been emergency officers, whose appointments became permanent.

Lord Lieutenants of Counties appear to have come into existence somewhere about the middle of the sixteenth century; they succeeded the Commissions of Array, which the Crown in earlier times had been accustomed to issue. The earliest of these appointments are to be recognised in the Commissions "de arraiatione et capitaneo generali contra Francos" issued, for a large range of counties of the kingdom, to the Dukes of Norfolk and Suffolk, and to the then Lord Russell, in 1545 .

Blackstone, however, says, "About the reigns of King Henry VIII. and his children, Lord Lieutenants began to be introduced as standing representatives of the Crown to keep the Counties in military order; for we find them mentioned as known officers in the statute 4 and 5 Philip and Mary, chap 3, though they had not been long in 
use, for Camden speaks of them (in the Britannia) in the time of Queen Elizabeth, as extraordinary magistrates constituted only in times of difficulty and danger."

This earliest known appointment by name is that of " the Erle of Bedford, appointed their Highnes Lieutenant of the Counties of Dorset, Devon, Cornewall, and their Citie of Exxeter, the I 7 th daie of March, the fourth and fifth yeares of their Majesties raignes."

The said Lieutenant is directed to have with him his Commission, his Instruction, and his Letters, and to depart forthwith to his charge with all diligence. $\mathrm{He}$ is to give orders for the raising of beacons and the control of same; to muster the men within his lieutenancy with their armour and weapons; to call the gentlemen of the shire together, and view their retinues of serving-men; to classify them as able horsemen and footmen, and to appoint fitting captains to lead each body; to view the horses fit for military service, and to appoint the places at which the troops are to muster when called upon. All dangerous landing places along the coast are to be noted, and the inhabitants are to be called upon to provide defences of " trenches and bulwarks of earth" at such places; while the inland dwellers are to furnish sufficient numbers to man these defences, providing each man with ten or twelve days' victuals.

The Lieutenant, if an enemy should land which is too strong for the local forces to contend with, is to withdraw his men to some place of advantage, destroying his trenches, cutting down trees and breaking the bridges behind him, and so impeding the advance of the invaders till aid can be sent him. In all towns diligent watch is to 
be kept; all seditions and dangerous rumours are to be strictly suppressed. In fact, it is laid down as the direct duty of the Lieutenant to take all measures for the due observance of the statutes regulating the musters of properly armed and equipped men, liable to serve the Crown in the defence of the country ; and he is particularly enjoined " to keepe the shire in good order and quiet, especiallie at the tyme of levying the subsidie."

Such were the instructions of "Marie the Queen," in 1558 . Similar instructions were given by Queen Elizabeth in June 1574, when the King of Spain was making a threatening demonstration against this country from the opposite shores of the Low Countries.

To ensure that there shall be no lack of men " trained in feates of warre," nor any deficiency in their proper "furniture of amor," " certaine honest chosen captens" possessing the necessary knowledge are to be appointed to the divers counties " there to teach and traine the people to understand how to weare their armour, use their weapons and doe such like thynges.

upon every holiday in the afternoone, in sundrie places to be chosen, meete for two or three moneths space"; at which the grave and discreet gentlemen of the county are " to be present and attendant for conservation of peace and good will." The shrewd Elizabeth enclosed with her instructions a schedule, so that no one liable should escape from " such assessments and appointments"; in fact the Lieutenant is expected to " augment the number of horsemen by meanes of putting in execution the intente of the saide schedule." And in this matter the Lieutenant's advice is sought for further means of augmenting the force of the shires, either in footmen or in 
horsemen, or in armour and weapons, " amongste the meaner sorte of farmers that be of secreat wealth and never before charged with service as the gentlemen be."

In committing the care and government of the aforementioned counties of Devon and Cornwall to the Earl of Bedford, " because they lie upon the Sea-coast," the adjoining counties of Dorset, Somerset, Wiltshire and Gloucestershire are ordered to give them any necessary aid and succour in time of danger, as are also the opposite coasts of South Wales. Nothing further calls for attention except that the Instructions contain a price list of the "Armour and Artillerie" then in use-the " armour of a dimi-lance" being valued at 54s. 4d. ; a corslett, 30s. ; " a currier complet," I6s. 8d.: " a harquebush," 8s. ; " a dagge complet," I6s. 8d. ; "a bowe of ewe," 2s. 6d. ; "liverie of arrowes and shafte," 22d. ; morris pike, 2s. ; halberd, 6s. 8d. ; a black bill, r6d., etc., etc.

A regular standing army was unknown in early England ; independent of the forces of feudalism the Fyrd was the only body of professed warriors. Previous to the reign of Henry VIII.-probably from the time of Edward I. - to protect the realm from invasion or domestic insurrection, it was usual for the sovereign to issue Commissions of Array, under authority of various Acts of Parliament, all of which were repealed in the reign of James I. Under these Commissions officers were sent into each county to array, that is, to set in military order the inhabitants of every district. It was provided that no man should be compelled to go out of the kingdom at any rate, and not out of the county except in cases of urgent necessity. In the Tudor period Commissions of Array were 
superseded by Commissions of Lieutenancy, although Charles I. afterwards issued a Commission of Array to call out the Fyrd. This revival was resisted as illegal, and in I642 it was ordered that Lord Lieutenants were to be appointed by Parliament, because he alone could call out the Militiaby which name the Fyrd, or national defensive force, had now come to be known. Every freeman between the ages of $I_{5}$ and 60 was not only liable to serve, but to provide his own equipment according to his social status; and to enforce the latter obligation in ancient times an Assize of Arms was held at certain periods, for the inspection of arms, armour, and other war material for personal equipment, in manner similar to that suggested in the Schedule just quoted.

The records of the Militia musters in olden times are very meagre, but the force was called together in 1539 , and for the Armada panic in 1588. It is difficult to find with any degree of certainty what part the Militia took in the Civil War (from I64I). In recent times the Militia has been embodied again and again-during the Peninsular and Waterloo campaigns, in the Crimean War, I854-6, and as late as the South African War. This ancient corps then became a sort of Special Reserve.

In the course of centuries the Fyrd considered as an auxiliary force, has had many different names-the General Levy, the Trained Bands, the General Militia, Armed Associations, Volunteers, and lastly the Territorials.

The standing army was established in the reign of Charles II., but the Militia finally became a body of voluntary recruits, trained for home defence, and who served for pay. The contingent of each county was prescribed by statute, based on the size of its population, and if the quota was not forth- 
coming voluntarily, a ballot of its able-bodied men might be enforced. Formerly the Militia was officered by the Lord Lieutenant and those appointed by him, but all high military authority has been vested, since I87I, in the Crown.

In his military capacity the Lord Lieutenant, till the Army Regulation Act of $187 \mathrm{I}$, was responsible for the efficiency of the Militia. Those powers and jurisdictions relating to the recruiting of the Militia by ballot, should that course have to be adopted, continued. The effect of recent enactments, however, has been to abolish the Lord Lieutenancy as a great military office.

The appointment of Lords Lieutenants in England dates from (cir) I549; in Ireland only from I83I.

The Lord Lieutenant is a great personage, usually a peer or large land-owner placed at the head of the county government, combining in himself the civil office of Custos Rotulorum and the military post of crown representative associated with the armed forces of the county. The military duties have shrunk to little more than mere patronage and ceremonial while in the other capacity the Lord Lieutenant may, if it should be necessary, preside at a general sessions of the justices.

As mentioned elsewhere, each of the Ridings of Yorkshire has a separate Commission of Lieutenancy, as a county in itself. In I660 Charles II. granted a Commission of Lieutenancy to the city of London giving the Commissioners similar powers to those possessed by the Lords Lieutenants of Counties; and by them the City Train Bands were remodelled and increased.

To each county there are a number of Deputy Lieutenants. The office of Deputy Lieutenant 
was also part of the organisation for national defence, but now it is little more than a social distinction, though the appointments and qualifications are regulated by the Militia Act, I882. At least twenty must be appointed for each county if there are so many therein qualified; the qualification requires that a Deputy Lieutenant must be a peer, or a peer's heir, resident in the county ; or the possessor of landed estate valued at not less than $£ 200$ a year, or of a similar income derived from personalty within the United Kingdom. These deputies are appointed by the Lord Lieutenant. 


\section{XIX \\ SHIRE BOUNDARIES}

Every place bearing the term " shire" as part of its proper name is not a shire in the sense of being a county division. The Anglo-Saxon "Scir" has had, at various times, divers meanings; it has not only signified a county, province, or district, but it came to be used in the sense of a boundary, or any object marking a boundary ; as " Shire-oak."

While giving some consideration to these, it may not be out of place to deal with those detached outliers of territory which used to give old county maps such a puzzling appearance.

There is a Shire-oak near Stonnal, Staffordshire, but it is a mile or two from the Warwickshire boundary; and a Shire-oak near Worksop, near the boundary of Notts and the West Riding of Yorkshire. Shirbourn, literally " the boundary brook," divides Coventry from the parish of Allesley; there are other places in the country similarly named and for the same reason. Shire Ditch, again, on the Malvern Hills, marks the boundary between Worcestershire and Gloucestershire.

The spot at which three or more counties come together has always been more or less a wonder place, a place to be marked and noted, a spot that was somehow distinguished above its surroundings. It was something to be able to stand in three counties at once. In the old prize-fighting 
days there was the spot near Birmingham, known as Three Shire Oak, at which the counties of Warwick, Worcester, and an isolated part of Salop came together, and provided a favourite place for pitching the ring, because when the constables of one county put in an appearance, there was a choice of two others through which the disturbed sportsmen could make their escape to quieter quarters.

The spot where the four counties of Warwick, Stafford, Leicester and Derby come together is known as No Man's Heath, and boasts a licensed rendezvous called "The Four Counties Inn."

If a thing is to be particularised and noted it must be named; so what more natural than the bestowal of proper names upon such spots. As boundary stones have been in use from the most remote times-pillars of stone and border stones are mentioned in the Bible, and in Anglo-Saxon times sucb landmarks were known here as hoarstones (now often corrupted into whorestones, warstones, and so on)-we get the place name Three Shire Stones in several parts of England. It is the name of the meeting-point of Lancashire, Cumberland, and Westmoreland (seven miles west of Ambleside) ; of the junction of Cheshire, Derbyshire, and Staffordshire $(2$ miles north of Flash) ; and of the meeting-point of Gloucestershire, Somerset, and Wilts (a few miles north of Bath). Near Cleeve Prior, where the shires of Worcester, Gloucester and Warwick come together is the Three Shires Elm. Four Shire Stones, again, is where the four counties of Worcester, Warwick, Oxford, and Gloucester meet, near to Moreton Henmarsh.

The modern town of Mossley is in Lancashire, Yorkshire and Cheshire, and the three municipal wards are named respectively after the counties. 
When the first great Reform Bill came to be passed, a rectification of the frontiers had to be made for electoral purposes, to overcome the difficulties arising from detached portions of some counties lying within the confines of other territorial counties. A few years later, other legal and administrative anomalies, which naturally attached to isolated fragments of a county lying away in some "foreign" area, were remedied by the Statute 7 and 8 Victoria c.62, which generally made them parts of the counties by which they were respectively surrounded.

No more absurd instance of this inconvenient arrangement could be found than that of Ely Place, Holborn, which was supposed to be in the county of Cambridge - the locality having anciently been the "inn" of the Bishop of Ely, the tenements known as "Ely Rents," though within the liberties, franchises, and jurisdiction of the City of London, long remained a " peculiar" jurisdiction of the Bishop of Ely, and was therefore accounted "part of the city of Ely in the county of Cambridge."

Here is a list of 52 such anomalies, compiled mainly from maps in Lewis's Topographical Dictionary :-

Part of

Situate in

Berks

Berks

Berks

Bucks

Bucks

Derby

Derby

Derby

Devon
Oxford

Oxford

Wilts

Northants

Oxford

Leicester

Leicester

Leicester

Dorset
Town or Village

Shilton

Little Farring'n

Caversfield

Ravenstone

Thorncombe 
Part of

Dorset

Durham

Durham

Durham

Gloucester

Gloucester

Gloucester

Gloucester

Gloucester

Gloucester

Gloucester

Hereford

Hereford

Hereford

Hampshire

Hertford

Huntingdon

Huntingdon

Kent

Monmouth

Oxford

Oxford

Oxford

Shropshire

Somerset

Stafford

Stafford

Suffolk

Warwick

Wilts

Wilts

Wilts

Wilts

Wilts
Situate in

Devon

Northumberland Bedlington

Northumberland Berwick-on-T.

Yorkshire

Hereford

Oxford

Oxford

Oxford

Warwick

Warwick

Wilts

Radnor (Wales)

Shropshire

Worcester

Sussex

Bucks

Bedford

Bedford

Essex

Gloucester

Buckingham

Buckingham

Buckingham

Worcester

Dorset

Worcester

Worcester

Cambridge

Worcester

Gloucester

Gloucester

Berks

Berks

Berks
Craike

Iea

Sherrington

Widford

Little Compton

Sutton-under

Brails

Minety

Litton

Farlow

Rochford

S. Ambersham

Coleshill

Swineshead

Everton

Grays (near)

Welsh Bicknor

Lillingstone

Lovell

Ashhampstead

Halesowen

Holwell

Clent \& Broom

Exning.

Tardebigge

Kingswood

Poulton

Hinton

Graisley 
Part of

Worcester

Worcester

Worcester

Worcester

Worcester

Worcester

Worcester

Worcester

Worcester
Situate in

Gloucester

Gloucester

Gloucester

Gloucester

Hereford

Oxford

Stafford

Gloucester and Warwick

Town or Village

Iccomb

Evenload

Cutsdean

Blockley

Edvin Loach

Dudley

Shipston

Daylesford

Gloucester \&

Oxford

The map of Scotland, too, often shows the enclave, fragments of Cromarty and Banff being dotted about other neighbouring counties.

The whole of Halesowen was not included in Salop. It is a large parish of several townships, one of which was in Worcestershire as its name, Warley Wigorn, testifies. But it did not consist of one piece; it was cut up into small patches and scattered among the townships of Oldbury, Langley, and Warley Salop, which were in Shropshire : some of these pieces were mere fields; some were larger and themselves enringed portions of Shropshire, so that on the smaller scale Ordnance Maps it was scarcely possible to distinguish the boundaries of the two counties.

It will thus be seen the limits of the shires have not been inviolably unchangable. As a matter of fact county boundaries have been altered by legal process from time to time, by transfers, and otherwise. Extensions and consolidations for convenience of local government have demanded that detached and outlying districts should be transferred to a nearer centre of administration. The list just given, of counties that once had 
separated fragments lying in the midst of neighbouring counties, is probably, by no means an exhaustive one.

The Thames is always considered the dividing line between Essex and Kent. But at Woolwich a small portion of the ancient manor lies on the opposite coast, in Essex-probably a piece recovered in olden times from the encroachments of the tide. On the other hand Chalk and Higham near Gravesend were anciently accounted parts of Essex. The Isle of Dogs, in Middlesex, has been claimed, but by what authority is unknown, as part of Kent.

It would be impossible to give all the instances in which county boundaries are known to have been altered. The present boundaries of Staffordshire by no means coincide with the limits recorded in Domesday Book. The boundary between Westmoreland and Cumberland, according to ancient surveys of manors, was not along the existing line of demarcation, the former county having evidently gained some time or other at the expense of the latter.

The names of several places in England have the terminal " shire," which are not counties, but which probably represent ancient lordships.

In Northumberland are to be found Norhamshire, Islandshire, and Bedlingtonshire, detached portions of the patrimony of St. Cuthbert. They were formerly included as parcel of the Palatinate of Durham. Norhamshire, a ward of over twenty thousand acres near the Tweed, formed till I844 a detached portion of the county of Durham. Islandshire, another Northumberland ward, containing some twenty-eight thousand acres, includes the Fern Islands, and also formed at one time a detached part of Durham county. Bedlingtonshire is a ward of over eight thousand four 
hundred acres, consisting of Bedlington parish, situated on the river Blythe, five miles southeast of Morpeth.

Hexhamshire (locally known as " the shire") is a division of Hexham parish in south Northumberland; of the 24,000 acres in the parish it embraces nearly 19,000 which once constituted a county palatine, comprising the parishes of Hexham, Iee St. John, and Allendale. This area was anciently governed by the Bishops of Hexham-it was in the year 684 St. Cuthbert was called to rule over this now long obsolete diocese. Subsequently it passed as a barony to the see of York, and in the reign of Elizabeth was annexed to Northumberland.

Besides these, Northumberland also contains Bamboroughshire, near the ancient castle and capital of the kings of Northumbria; and the Shire Moor at Backworth, near North Shields.

In the county of York are Hallamshire, Howdenshire, Richmondshire, and Allertonshire. Hallamshire is an ancient lordship of the southern division of the West Riding, mentioned in Domesday Book as Hallam. Its boundaries are now difficult to determine, but they are generally supposed to embrace the parishes of Sheffield and Ecclesfield. Howdenshire is a wapentake (and now a parliamentary division) in the East Riding. Richmondshire contains the five Wapentakes of Gilling East, Gilling West, Hang East, Hang West, and Halikeld; roughly speaking it is bounded on the north by the river Tees, on the south by the river Ure, on the west by Westmoreland, and on the East it reached about as far as Northallerton.

Allertonshire is the name of another Wapentake in the North Riding. 
The application of the term " shire" to these northern districts originated in the Middle English period, probably with the monks, who seem to have employed it to denote certain undefined localities or regions that never had any exact geographical existence. 


\section{$\mathrm{XX}$}

\section{COUNTIES CORPORATE AND COUNTIES PALATINE}

For upwards of a thousand years the whole realm has been so divided for its better government that there is no part of the kingdom which does not lie within some county.

Besides the geographical counties, of which there are forty in England and twelve in Wales, there are counties corporate, certain towns or cities with lands and territories, having liberties and jurisdiction by grant from the king; as the county of Middlesex annexed to the city of London by Henry I; as the county of the city of York (tempo Henry VIII.), of the City of Chester (Elizabeth), of the cities of Bristol, Gloucester, Norwich, Worcester, etc., and the county of the town of Kingston-upon-Hull, and others.

Centuries before that modern invention, the " county-borough," was heard of, certain cities and towns in this country enjoyed the privilege of ranking as counties in themselves. They were " counties corporate," distinct from the geographical counties in which they were situate -they all lay, with the possible exception of Berwick-upon-Tweed, within the defined limits of territorial counties.

This superior status had been acquired by virtue of county privileges conferred upon them, generally as a mark of the royal favour in former times. Still, though the two classes of counties 
are generally considered to be on the same footing in strict theory of law, they are in no way so in actual practice.

The legal constitution of these privileged places has been thus set forth :

"There are counties corporate-otherwise called counties of cities or towns-which are certain cities and towns, some with more, some with less territory annexed, to which out of special grace and favour the kings of England have granted the privilege to be counties of themselves and not to be comprised in any other county; but to be governed by their own sheriffs and other magistrates so that no officers of the county at large have any power to intermeddle therein."

As counties corporate constitute no part of the counties in which they are locally situate, so they had formerly in general no share in voting for the members to serve for those counties in parliament. However, thirteen of the number were latterly included within their respective counties, so far as regards the right of election for knights of the shire; and this tendency has been largely followed in the later Redistribution Acts.

Nineteen old towns have been so distinguished, most of them cities. London was a county by prescription at the Norman Conquest; the others have been separated from their parent counties since that epoch.

Bristol, formerly part of Gloucestershire, was invested with independent jurisdiction by a charter 47 Edward III., which is the earliest instance.

York was made a county by Richard II.; Lincoln, Norwich, and Newcastle-on-Tyne, by Henry IV. ; Hull, Nottingham, Southampton, and Coventry, by Henry VI.; Canterbury and Haver- 


\section{Counties Corporate and Palatine i87}

fordwest by Edward IV.; Gloucester by Richard III ; Chester by Henry VII.; Exeter by Henry VIII.; Lichfield by Mary; Poole by Elizabeth; Carmarthen and Worcester by James I.

From its position on the boundaries of two kingdoms, Berwick-upon-Tweed was the scene of frequent conflicts prior to the union of England and Scotland under James I. The town itself was included under the English crown in the reign of Edward IV.; and although it was made an independent town by Edward VI., and referred to separately in national and legal documents, it was still considered to belong to England. The town is still defended by fortifications, which, though out of date, form an agreeable promenade. Edward I. granted Berwick a charter of incorporation, and James I., by a new charter, conferred on the corporation the seignory of the town and 3,077 acres of land within the borough.

It will be observed that two of these corporate counties have been carved out of Northumberland (Berwick and Newcastle); two out of Yorkshire (York and Hull) ; and two out of Gloucestershire (Gloucester and Bristol). Kent has lost the area of Canterbury, Cheshire of Chester, Devon of Exeter, Staffordshire of Lichfield, Lincolnshire of Lincoln, Norfolk of Norwich, Notts of Nottingham, Hampshire of Southampton, and Worcestershire of Worcester.

The county of Hull, or rather Kingston-uponHull, include s a strip of land five miles westward from the town.

The "city and county of the city of Lincoln" comprises the city together with four adjacent villages; the remainder of Lincolnshire, which is the second English county according to area, is divided into three parts, namely Lindsey, Kesteven, and Holland. 
Poole, in Dorsetshire, created a separate jurisdiction under the style and title " the County of the Town of Poole," by charter dated 23rd June, I568, is the smallest of the class, and no assizes are held there.

Coventry was re-annexed to Warwickshire in the reign of Victoria.

Only two towns of this status are in Wales, namely Haverfordwest in Pembrokeshire, and Carmarthen. There are none in Scotland, but Ireland has nine of them, namely Dublin, Carrickfergus, Cork, Drogheda, Galway, Kilkenny, Limerick, Waterford, and (since I663) Londonderry.

It is interesting to note that the term " county borough" was applied to Cærmarthen in an old document of William III.- the earliest known use of the name.

There are also three counties of special status, known as Counties Palatine; namely Lancaster, Chester and Durham. Ely possesses certain royal franchises, and is sometimes erroneously described as a county Palatine.

Counties Palatine were probably erected at first because they were adjacent to an enemy's country, as were Durham and (perhaps) Lancaster to Scotland, and Chester to Wales; that the inhabitants might have administration of justice at home, and remain there to secure the county from incursions.

These Counties Palatine are reckoned among the superior courts, and are privileged as to pleas, so that no inhabitant of such counties shall be compelled by any writ to appear or answer out of the same, except for error, and in cases of treason. 
A Tudor chronicler, says that in the time of Edward III. Lancaster, Durham, and Ely, and Hexhamshire in the western part of Northumberland, were reputed counties palatine; also Chester, created so by the Conqueror, who gave these earldoms " to be beld as freely as the king held his crown," and "by this supremacy of liberty" he made himself barons which might assist him in council.

The legal status of the County Palatines is fully defined in Stephen's Commentaries :-

Three counties, viz.. Chester, Durham, and Lancaster, are counties palatine. The two former are such by prescription or immemorial custom, or at least are as old as the Norman Conquest; the latter was created a county palatine by King Edward III., in favour of Henry Plantaganet, first earl and afterwards Duke of Lancaster: whose heiress being married to John of Gaunt the King's son, the franchise was greatly enlarged and confirmed in parliament, to honour John of Gaunt himself ; whom, on the death of his father-in-law, the King had also created Duke of Lancaster.

Counties palatine are so called $a$ palatio, because the owners thereof, the Earl of Chester, the Bishop of Durham, and the Duke of Lancaster, had formerly in those counties jura regalia as fully as the king in his palace; regalem potestatem in omnibus, as Bracton expresses it.

They might pardon treasons, murders, and felonies; they appointed judges and justices of the peace; all writs and indictments ran in their names, as in other counties in the King's; and all offences were said to be done against their peace, and not as in other places, contra pacem domini regis. As to which indeed it may be remarked that by the antient law, in all peculiar jurisdictions, offences were said to be done against his peace in whose court they were tried : in a court leet, contra pacem domini; in the court of a corporation, contra pacem ballivorum; in the sheriff's court or tourn, contra pacem vice comitis.

These palatine privileges are similar to the independent regal jurisdictions usurped by the great barons on the continent during the weak and infant state of the first feodal kingdoms in Europe.

Take the palatinate of Chester by way of example. The only part of Wales found assessed to the English King in Domesday Book was the region of Mold and Flint, which then formed part of the great county palatine of Chester. For the Conqueror had made over this portion of the Welsh Marches to Hugh Lupus, Earl of Chester, with and some of it apportioned into counties, the 
leave to add to his palatinate as much territory as he could conquer from the Welsh; and he had carried his annexations as far as Rhuddlan Castle. At that time the Chester palatinate also included the part of Lancashire lying between the Mersey and the Ribble; but this was afterwards transferred to the county palatine of Lancaster, at its creation by Edward III. ; a little earlier when Wales was being subjugated by Edward I., Flintshire portion had been taken out of the county of Chester, though the Sheriff of Flint was to attend before the justice of Chester and bring his accounts to the Exchequer of Chester.

Tersely and succinctly the further history of the English Palatinates is thus given in Stephen's Commentaries :-

It is also to be remarked, that of the counties palatine none of them now remain in the hands of a subject. For the earldom of Chester, as Carnden testifies, was united to the crown by Henry III., and has ever since been one of the titles of the sovereign's eldest son ; and the palatine jurisdiction of Durham whlch was long vested in the bishop of Durham for the time being, was taken from him by 6 and 7 Will IV. c. 19.. (amended by 21 and 22 Vict c. 45) and vested as a separate franchise and royalty in the crown.

As to the county palatine or duchy of Lancester, it was the property of Henry Bolingbroke, the son of John of Gaunt, at the time when he wrested the crown of King Richard II., and assumed the title of Henry IV. But he was too prudent to suffer his duchy to be united to the crown; lest if he lost the one he should lose the other also. For as Plowden and Sir Edward Coke observe, " he knew he had the duchy of Lancaster by sure and indefeasible title, but that his title to the crown was not so assured : for that after the disease of Richard II., the right of the crown was in the heir of Lionel Duke of Clarence, second son of Edward III. ; John of Gaunt, father to this Henry IV., being but the fourth son.

" Harry of Lancaster," when he became King in I399 was naturally anxious to have his Duchy to fall back upon if he should lose the crown, so he obtained an Act of Parliament which prevented the lands which go with the Duchy from being merged or mixed with the lands which go with the crown. The Crown lands were surrendered by 
George III. on his accession in return for a fixed salary as King, but by virtue of this old Act of Henry IV. - re-enacted several times-the revenues of the Duchy of Lancaster, which are derived from property not only in Lancashire, but in other parts of the country, remain a source of private income to the King. In I9I3 their value to the King was $£ 6 r, 000$.

The origin and nature of the peculiar privileges belonging to the Palatinate of Lancashire are curious and interesting. In John of Gaunt, fourth son of Edward III., and so called from being born at Ghent, was revived, by declaration of Parliament in 1362 , the title of Duke of Lancaster. Several royalties were further conferrred upon him by his father, including to the County of Lancaster the dignity of a Palatinate. The terms in which the royal patent was granted are noteworthy.

“ We have granted for ourselves and our heir (John) that he shall have, during life, within the county of Lancaster, his Court of Chancery and writs to be issued out under his seal belonging to the office of Chancellor; his justices both for holding the pleas of the crown, and for all other pleas relating to common law, and the cognizance thereof, and all exactions by his writs and offices within the same : and all other liberties and royalties relating to the County Palatine, as freely and fully as the Earl of Chester is known to enjoy them within the county of Chester."

The King's next care was to establish a Court entitled the Duchy Court of Lancaster for the administration of all matters affecting the possessions under the Duchy.

In London, at Lancaster Place, Strand, this Court is now held, and from thence issue all patents and commissions of office or dignities, and all orders or grants relative to the revenues and limits, and all acts of authority within the duchy. 
On the site of the Palace of the Savoy was the ancient residence of the Dukes of Lancaster. It was so magnificent that according to Knighton, there was no mansion in the realm its equal in stateliness and beauty. John of Gaunt lived at the Savoy in almost regal state.

Under Henry V. the prerogatives, privileges and possessions of the Duchy of Lancaster, held by his father, Henry confirmed, and with the sanction of Parliament it was directed that the liberties and franchises of this Duchy should be maintained and exercised for ever, and that the seal of the Duchy should have force without reclamation of the King, or of his officers, and be used for ever in the business of the Duchy. Further, "possessions in hereditary right of the King were separated from the Crown and incorporated in the Duchy of Lancaster to be administered by the officers of the Duchy." Again, under Henry V. and Henry VI., the possessions of the Duchy of Lancaster were added to, and validity of independent administration extended. The attainder of Henry VI. by Edward IV. declared the Duchy of Lancaster forfeited to the Crown. Nevertheless, an Act was passed " to incorporate the Duchy of Lancaster, to continue the County Palatine, and to make the same, parcel of the Duchy 'vested' in whole in King Edward IV., and his heirs Kings of England for ever, but under separate guiding and governance from the other inheritances of the crown."

In the reign of Henry VII. another Act was passed to resume such part of the Duchy lands as had been dismembered from it in the reign of Edward IV. and to vest the whole " in the King and his heirs for ever as amply and largely, and in like manner, form, and condition, separate from 
the crown of England, and possessions of the same, as the three Henrys and Edward IV. or any of them had and held the same."

Henry VIII. very much impaired the revenues, by his gifts and grants to favourites, and otherwise, but all the possessions were restored under Mary. From the reign of Elizabeth the Duchy of Lancaster has been considered one of the richest gems in the Crown of England, and the Sovereigns have borne the title of Duke of Lancaster, enjoying " the most famous princliest, and stateliest of inheritances." But for state purposes the Duchy has been kept quite distinct from the regal revenues and possessions.

The Chancellor of the Duchy of Lancaster is a statesman who changes with the Government and holds office by letters patent, taking precedence (if not a peer) next after the Chancellor of the Exchequer.

The Chancellor of the Duchy, as such, has next to nothing to do. The Vice Chancellor presides over the Chancery Court which was left to the Duchy even by the clean-sweeping Judicature Act, and the management of the estates is done by a staff of receivers and solicitors and surveyors. When he has made an appointment to any vacant county court judgeship within the limits of the Duchy, the Chancellor has done the most, if not quite all, of what he has to do, and the office has in the past been held by some politician of eminence but of a mind better at the principles than the details of statesmanship. Nowadays the Chancellor of the Duchy often fills in his time with unclassified administrative work.

Although this county palatine came directly under the Crown, it retained all its privileges, and it was not until the last century that the ad- 
ministration of justice was assimilated to that of the rest of England.

With regard to the Isle of Ely, we may observe (says Stephen) that this was never a county palatine, though some times erroneously called so. It was, however, a royal franchise; the Bishop of Ely having been formerly entitled, by grant of King Henry I., to jura regalia within the district, whereby lie exercised a jurisdiction over all causes, as well criminal as civil. But by 6 and 7 Will IV.c. 87 (amended by 7 Will. IV.and I. Vict. c. 53) this secular authority of the bishop was taken away and vested in the Crown.

There were formerly two other counties palatine, Pembrokeshire and Hexhamshire (the latter now united with Northumberland), but these were abolished by Parliament; the former in 27 Henry VIII. the latter in I4 Elizabeth. At the former period, moreover, the powers before mentioned of owners of counties palatine were abridged; the reason for their continuance, says Stephen, having in a manner ceased.

And in recent times, alterations have taken place in regard to the administration of justice in the counties palatine, which have assimilated them in that matter to the rest of England. Thus by II Geo.IV. and I Will.IV.c. 70 the jurisdiction of the court of session of the county palatine of Chester was abolished, and that county was subjected in all things to the jurisdiction of the superior courts at Westminster; and by the Judicature Act, I873, the jurisdictions of the Court of Common Pleas of Lancaster and of the Court of Pleas of Durham were transferred to the High Court of Justice by that Act established. 


\section{XXI.}

\section{COUNTY QUARTER SESSIONS, COUNTY COUNCILS, AND COUNTY COUR'TS.}

In the counties the two inferior courts of the land are the Court of Quarter Sessions, with criminal jurisdiction, and the modern County Courts for civil cases. They are the principal of the inferior courts.

In the Court of Quarter Sessions we may recognise the modern form of the judicial powers of the old Shire-moot. We have seen that formerly the judicial function was largely exercised by the Sheriff, the King's representative, one of the three officials who originally presided over that assembly. Then as the importance of the Sheriff waned, his judicial powers passed in a large measure to the Justices of the Peace.

At first these newer officials exercised no judicial authority at all; and even when they did it was only in their corporate capacity. Justices of the Peace seem to have been appointed in the first instance to enforce the carrying out of the oath of peace, which the Archbishop of Canterbury laid upon the land in the reign of Richard I.

Afterwards they were elected in the Shire Court, but at the beginning of the reign of Edward III they were nominated by the Crown. This is the system which now holds good, the Crown appointing on the advice of the Lord Chancellor, who acts on the recommendation of the Lord Lieutenant of each county. 
In time the Justices of the Peace came to be numbered among the most important officials of the kingdom. Gradually the care of all matters concerning the countryside-the rural areas outside the cities, boroughs, and corporate townscame to be placed in their hands; beginning with the remedial efforts necessitated by the deplorable state into which the country had fallen, through the Black Death (I348-9); going on to the administration of the poor laws of the Tudor Period; and coming gradually into the control of all matters relating to local government.

Magistrates give their services gratuitously, and have jurisdiction within a certain area, generally acting for the neighbourhood in which they reside; as custodians of the King's peace they preserve order, put down disturbances, and act as judges in minor cases.

In I888 the county magistrates were largely relieved of their old administrative duties, but left in possession of their judicial functions.

These judicial duties fall into two groups; the Appellate, or the hearing of appeals from Petty Sessions; and the Original, or the trial of offences too serious for the courts of summary jurisdiction to deal with, but not serious enough to demand trial before a judge of Assize.

The Sessions, as their name would imply, are held four times a year*, for the trial of lesser criminal cases in each county ; most of the large towns, too, hold them, in which the judge, a barrister appointed for the purpose, is known as the Recorder. In the counties the Court is held before the Justices of the Peace, of whom one is

*The first whole weeks after October II, December 28, March 31 . and June 24. These Sessions may be adjourned from time to time and from place to place 
elected permanent Chairman, and acts as Judge, though he usually consults the others as to the sentence. Murders, manslaughters, and other very serious cases cannot be tried before these courts, and have to be reserved for the Assizes.

The procedure of this court is very similar to that observed at the Assizes. At the commencement of the Sessions all the cases go before a Grand Jury, and the trial takes place before a common jury.

A pungent eighteenth century satire on the functions of this court is contained in some "Lines on a Country Quarter Sessions" :

Three or four parsons, three or four squires,
Three or four lawyers, three or four liars ;
Three or four parishes bringing appeals
Three or four hands, and three or four seals ;
Three or four bastards, three or four whores-
Tag, rag, and bobtail, three or four scores ;
Three or four bulls, three or four cows
Three or four orders, three or four bows ;
Three or four statutes not understood,
Three or four paupers praying for food ;
Three or four roads, that never were mended,
Three or four scolds-and the Session is ended.

Not the least important county functionary is the Coroner, whose office is both ancient and honourable-he is so called because he deals wholly and exclusively with the king and crown, and yet he was the only county official not appointed by the crown, being elected (generally for life) by the body of freeholders.

There are about ten Coroners to each county, in addition to a number of Borough Coroners.

For the object of local taxation, says the learned Stephen, the division into counties is of practical effect and importance; " for as each parish is subject to a rate for relief of the poor, so is every county to a county rate, which is levied on the occupiers of land within the county under the 
authority of various acts of parliament and applied to many miscellaneous purposes." But as the allocation ard spending of most of this money was in the hands of the Court of Quarter Sessions, a nominated and unrepresentative body, here was an instance of " taxation without representation," which called for the attention of the reformer at an early period of reforming era.

When the great majority of the population lived in the country, as they did up to the eighteenth century, the power of the country gentry, or " squires," was enormous.

For thirty years the subject of the administration of county affairs by authorities in some degree representative of the inhabitants of the rural districts and the country towns and villages was constantly before the public, the topic being discussed over and over again among Chambers of Agriculture and similar bodies. A Bill introduced in 1852 proposed to ignore the Quarter Sessions and give the control of county business to boards elected by the Guardians of the Poor. A more vigorous attempt to place county government on a sound footing was made in I87I, when it was proposed to consolidate the rate and institute parochial boards, whose chairmen were to elect from among themselves a certain number (to be fixed by the justices) of parochial representatives for each petty sessional division. The Magistrates in Quarter Sessions were to elect from among themselves a number of members equivalent to the total number of parochial representatives. Of course a property qualification was to be necessary in both-the former of $£ 30$ rateable value; in the latter of $£ 40$ per annum. 
There were other proposals at various dates for the constitution of County Boards, and it was generally noticeable that it was almost invariably sought to represent two interests - the " ratepayers," by which term the smaller occupiers were denoted, and the "magistrates" who were then commonly supposed to be representative of the owners. Although the ultimate aim of occupier and owner might be identical, namely the economical and efficient administration of county affairs, it was felt that their views and their interests would probably not always coincide-the absentee owner, for instance, might be a source of trouble in the working of such a system; and the justices again were an utterly irresponsible body, the nominees of a higher authority, equally non-representative. Of the many crude proposals none became law; in the meantime the principle of free and direct election gathered strength in the public mind. Public opinion gardually shaped itself into a demand for the free and unfettered choice of men who were anxious and qualified to conduct the public business of the neighbourhood in which they resided, whatever their status or their calling-whether they were magistrates, peers, clergymen, yeomen, manufacturers, farmers, or tradesmen, it mattered not so long as they were animated by the proper public spirit.

The reforming ideas of the nineteenth century could no longer tolerate the administration of county affairs by a non-elective body. That the control of the county police, the management of main roads, and other matters necessitating the expenditure of public moneys, compulsorily contributed in the shape of rates, should be in the hands of the county magistrates, came to be re- 
garded as unsatisfactory. So in I888 the Local Government Act was passed constituting an elective authority called the County Council to whom these powers were transferred, and many new ones added.

For the better local governance of the countryside, and in further vindication of the great English principle, no taxation without Representation, the County Councils were created. These popularly elected bodies were to be chosen every three years, to consist partly of County Councillors and partly of aldermen elected by the council generally from their own body, but not so of necessity, power being given to the councils to go outside in the exercise of their choice.

I888-County Councils established in England and Wales (London being made a separate County).

I889-County Councils established in Scotland ; I898-County Councils set up in Ireland.

The great towns had long demanded and obtained a reformed municipal government. But the outside rural districts, the villages and the towns too small to command a perfect system of local government of their own, had been administered by the county magistrates. These administrative areas, as they were called, had varied very much in their size and needs, according as the county could be classified as agricultural or as manufacturing.

In the latter the density of population and corresponding wealth, contrasted widely with the difficulty of raising adequate sums from the rates in the former wherewith to provide for the public requirements of the area. Thus the manufacturing county of Lancashire was found with an area very little in excess of that of Hampshire, 
County QuARTER SESSIONS, CouncILS, \&C. 201

to have nearly six times the population, and more than five times the rateable value.

The towns maintained their independence of the county, the larger boroughs in absolutely every detail of local autonomy, and the smaller municipalities generally in those matters which are considered vital to the principle of local selfgovernment. Sixty-four towns in England and Wales which had attained to a population of about fifty-thousands and upwards, were endowed with the fuller powers of the first category and were styled County-Boroughs.

Originally the basis of population put down for a county borough was 150,000 , which was reduced to 100,000 , and finally to 50,000 . It is not surprising that County Councils which have suffered the dismemberment of their areas, where the most populous and prosperous of units have grown into county boroughs, have complained of the hardship inflicted on them, the county authority being left with a residue of a poor rural population scarcely able to provide the money for the necessities of government.

London which had always occupied a different position from that of other towns in the kingdom, was provided with its own County Council consisting of 138 members, and having jurisdiction over the district till then governed by the Metropolitan Board of Works, a body which was thereupon abolished. Of course the city (that small area in the heart of London, the population of which did not reach the standard set up for a county-borough) was left in the enjoyment of its ancient form of government by Lord Mayor and Corporation.

The Act of 1888 undoubtedly made a great advance in the form of efficiency of English pro- 
vincial government, the strength of which, as compared say with France, is the comparative freedom from central authority, each County Council being in essence a provincial parliament.

With our usual fear of sudden and violent change and our preference for compromise, the control of the police and other matters relating to the administration of justice within the county area, was vested in a Standing Joint Committee of Quarter Session and the County Council.

Between the County Courts of the present day and the early Sheriff's Court there is no historical connection.

The modern County Courts came into existence in 1846 at which date England was divided into fifty-six circuits, each containing a certain number of district courts, which are held at the principal towns in each circuit. Over each circuit is appointed a Judge, chosen by the Lord Chancellor from among barristers of at least seven years' standing, and who is addressed as "Your Honour." The principal cases tried in these courts are claims for debts under $£ 50$, and civil cases in which the amount of damages does not exceed $f_{50}$. New functions may be, and are, added, from time to time. Courts are held at short intervals and the Judge has the assistance of a registrar and other officers. A jury of five persons may be summoned if the amount claimed exceeds $£ 5$, and either of the suitors so wish. The procedure is simple and inexpensive, and it is essentially a " poor man's court."

"These antient courts (says Stephen, tracing the history of the Shire Courts) retain at the present day nothing of their former consequence, and are not now entrusted with the administration of 


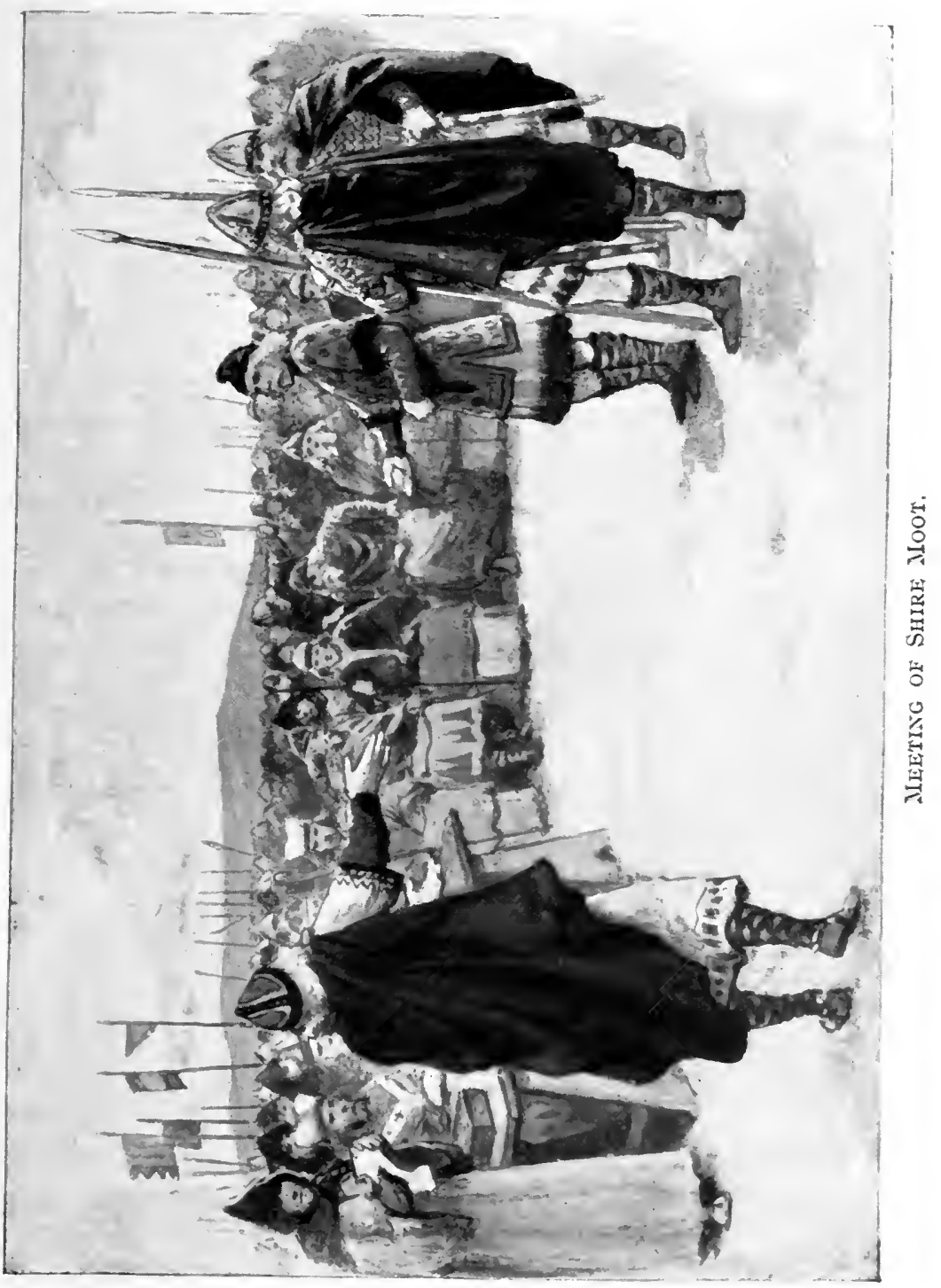



County Quarter Sessions, Councils, \&C. 203

justice. The County Courts of modern institution have been nevertheless established in reference to the old territorial division, there being for each county one of these courts held in one or more places within its limits; also, as regards crime, the trial is, as the general rule, conducted in the county wherein the offence is alleged to have been committed; and such trials take place either before the judges and commissioners of Assize, on their periodical circuits, or else before the justices of the peace for the county at their Quarter Sessions."

Cornwall and Devon have peculiar courts of law, of ancient privilege, for the administration of justice among the tin-miners. They are called Stannary Courts (from the Latin stannum, tin) and are held before the Lord Warden and his substitutes, officers of the royal Duchy.

An independent jurisdiction was given by William the Conqueror to the Cinque Ports, which were erected into a sort of palatinate, with a Lord Warden invested with civil, military, and naval jurisdiction. Each of the five ports had its own corporation of twelve jurats with peculiar powers and privileges ; but within the last century the ancient organisation of the Cinque Ports has been broken up, to bring the towns into line with modern forms of government.

In the bestowal of this Conqueror's privilege may be traced the foundations of the Royal Navy, "the senior service," as a recognised national force. Before the Tudor period the monarch relied on the service of fifty-seven vessels, each carrying twenty-one men and a boy, which ships had to be provided by the Cinque Ports, free of expense for fifteen days-but only after they had received forty days' notice from the Crown. 
When a greater force was required ships were hired -from merchants at home, or even from foreign ports such as Dantzig, Hamburg, and Genoa. When the Spanish Armada was tackled in Elizabeth's time, this country sent out 176 ships carrying 14,992 men, but of these only 34 ships and 6,225 men belonged to the Crown.

According to the Report of the Commissioners for revising and digesting the civil affairs of the Navy, issued in I805, there was a sort of naval force in existence in the time of Henry VII., but it was not known as the Royal Navy-it was mainly the obligatory contribution of the Cinque Ports.

In I883 an Act to reform municipalities abolished 42 ancient Courts of Record, but four times that number still exist, though some of them do not exercise their jurisdiction. Abingdon, for instance, has jurisdiction in personal actions up to $f$ ro, but its jurisdiction has been in abeyance since 1836: Andover and Banbury courts have jurisdiction to $f 40$ : Bedford Court has been in abeyance since $I 789$; but these rights are not lost by mere non-user. Some courts like the Barmote of High Peak had chartered jurisdiction relating to mining rights ; but this, and the Barmote of Wirksworth are now regulated by statute.

Bristol court possesses the power of foreign attachment; at Cambridge the Chancellor's Court had a wide jurisdiction, though since 1856 its powers in criminal matters have been largely curtailed, and it has since practically fallen into disuse. At Liverpool there is a Court of Passage which still carries on an extensive business. In London the Mayor's Court is an ancient court of record; and there is also the Court of Husting with a special jurisdiction in cases of debt and damage. 
County Quarter Sessions, Councils, \&C. 205

Another peculiar jurisdiction belonging to the city of London is that of the Chamberlain's Court, dating from the time of Edward VI. It was instituted to determine disputes between masters and apprentices, the judges being the Chamberlain and Vice-Chamberlain of the city.

Salisbury has by prescription a Bishop's Court with civil jurisdiction, but no trial has taken place in it since 1816 , and it has been in abeyance since I846.

Arundel Court has not exercised jurisdiction since 1798 , or Beaumaris since 1779 , and the last trial in Bath Court of Record took place in I82I. The Banbury Court had its procedure revived by the late Sergeant Talfourd when he was Recorder of that town. Birmingham affords the last instance of the grant of a local court by royal charter, Queen Victoria favouring that borough in this respect in 1838. The Recorder of Birmingham is still judge of that privileged court, though it has not held a session for many years past.

Like Cambridge, Oxford University has a Chancellor's Court with exclusive criminal jurisdiction, where the defendant is a member of the university.

The Hundred Courts have practically all disappeared ; the well-known Salford Hundred Ccurt, notwithstanding its name, does not come down to us in unbroken succession from its ancient precursor of that name. It is a court of record which has been established by statute in substitution for, and as an amalgamation of, two ancient courts, the Salford Hundred Court and Manchester Court of Record.

These few instances will suffice to give the reader a faint idea of the ancient courts possessing a local jurisdiction, and their status at the present day. 


\section{XXII}

\section{THE GEOGRAPHICAL COUNTIES}

The geographers not unnaturally group the counties according to position. In the first group are placed the four northern counties which lie east and west of the Pennines, two on one side, two on the other, all having a sea-board, though Westmoreland has not much to boast of. Northumberland, lying between the Tweed and the Tyne, consists very largely of sloping moors between the Pennines and the sea, but the poorness of the land is more than made up for by the possession of one of the largest coalfields in Great Britain. The county of Durham, on the same slope towards the North Sea, lies between the Tyne and the Tees; it also is rich in prolific coal measures and other mineral wealth, which find an outlet through the Wear and the Tees. On the other side of the divide the county of Cumberland has its scenery boldly dominated by mountain and lake-here are the highest mountains in England interspersed with fifteen of its largest lakes-and diversified by the moorland waste of the Pennines and the fertile valley of the Eden. Westmoreland is also a county of mountain, moorland, and lake, and with the previously named county constitutes one of the rainy regions of England. As a part of Northumbria, Westmoreland was once known as Applebyshire. 
The counties of the Humber basin include not only Yorkshire to the northward, but the four others southward, drained by the Trent, namely Nottinghamshire, Derbyshire, Leicestershire, and Staffordshire. Yorkshire comprises the basin of the Ouse ; it is the largest county in England and ranks third in point of population; I ancashire coming first, and Middlesex second. Over on the continent may be found kingdoms less in size, and much inferior in wealth. The Vale of York is the largest in England. In the North Riding are the elevated Yorkshire moors; in the East Riding the Yorkshire Wolds; and in the West. Riding are found the coal and iron, and the great woollen manufacturers, which have filled it with populous towns and made it one of the busiest and richest districts in the world.

The county of Nottingham is a flat rolling country along the lower Trent, whose memories of old romance in Sherwood forest are now fading fast before the industrial advances of its rapidly developing coalfield. Derbyshire, with its tors and peaks, its grand caverns hollowed in the limestone cliffs, and its rounded hills cut by wild glens, has been called the English Switzerland; it possesses river scenery along the Dove and the Derwent that can scarcely be surpassed in any Alpine region. With the delightful region of this limestone formation is sometimes associated the prevalence of the distressing disease, goitre, locally known as Derbyshire Neck, and commonly attributed to an excess of lime and magnesia in the water.

Leicestershire, the smallest of the Midland counties, is composed chiefly of the valley of the Soar, and belongs to the Central Plain of England, across which an extensive view is obtainable from 
the uplands of Charnwood Forest, the only elevated land within 1ts boundaries.

Staffordshire is a Midland county with twin coalfields; that of the north has bred the Potteries, that of the south, with its famous ten-yard seam, has produced the Black Country. These two famous industrial regions are separated by a fertile belt of pleasant agricultural country, which is never recognised as characteristically " Staffordshire."

Lancashire and Cheshire belong to the basins of the Ribble and the Mersey, and lie between the western slopes of the Cumbrian and Pennine mountains and the Irish Sea. In North Lancashire the peninsula of Furness is cut off by Morecambe Bay. South Lancashire has the superficial aspect of barren moorland, but beneath the surface lies one of the richest coal-cellers in the kingdom, and hence this county has become the greatest of England's industrial centres, the enormous traffic of its cotton manufactures finding every necessary facility of waterway in the river Mersey. Lancashire has been known as the Cotton County since the early seventeenth century. Geographically it is the most artificially constructed county in the kingdom, no natural connection binding together isolated Furness in the north, the region between Morecambe Bay and the Ribble anciently known as Amunderness, and the southern region formerly known officially as " Between Ribble and Mersey." Furness was originally part of the Strath-clyde Welsh kingdom ; Amunderness long counted as an outlying district of Yorkshire ; and the southern part, under the old names of Blackburnshire and Salfordshire, belonged to the county palatine of Chester. Not till the time of Henry III. were all the lands of 
Lancashire resumed by the Crown and made into an administrative whole, Edmund Crouchback then being created Earl of Lancaster.

Cheshire consists of a low and rather flat plain with a light soil, drained by the Mersey, the Weaver, and the Dee ; from its luscious grasslands come the famous Cheshire cheese and other forms of dairy produce; from its inexhaustible mines of rock-salt it has been dubbed the "salt-cellar of England."

The six west-midland counties in the basin of the Severn form a group; namely Shropshire, Worcestershire, Warwickshire, Gloucestershire, Herefordshire and Monmouthshire. The last two, which lie west of the Severn, were included in the government of Wales till the time of Henry VIII. ; Warwickshire is in the basin of the Avon, the largest tributary of " fair Sabrina."

Shropshire lies amongst the upper waters of the Severn; one part of it belongs to the Welsh group of mountains, another to the Plain of Cheshire, and a third part belongs to the Central Plain. Across the western edge of Shropshire is to be seen the earthen dyke erected between the Dee and the Wye, by Offa, King of Mercia, in 779, to mark the Welsh frontier. Then the Salopian plain begins to rise into humps and domes that stretch westward, till they merge into the higher peaks of the Welsh mountains.

The county of Worcester is a broad rich valley bordered on each side by a range of hills ; on the west by the lovely Malverns, and on the east, the Clent Hills-the latter, the first interruption of the great Central plain standing up a thousand feet in the centre of England, and dividing threeways the waters of the Trent, the Thames, and the Severn. The north-east corner of this fruitful 
garden-county joins up to, and takes upon itself the barren nature of, South Stsffordshire's laborious wastes.

Warwickshire, fair, pleasant, and " very English" in its hedgerow scenery, belongs to the Central Plain, and is the " heart of England."

Gloucestershire occupies the lower Severn valley, a fine fertile stretch between the rugged heights of Dean Forest on the west, and the rich grazing slopes of the Cotswolds on the east.

The county of Hereford is filled by the larger part of the basin of the Wye, one of the loveliest rivers in England; while Monmouthshire, the English county which is most Welsh, occupies most of the basin of the Usk. It is through the latter also that, as the poet expresses it, the Wye " slides with all her beauty into Eternity."

The East-Midland counties, or counties of the Wash, comprise Lincolnshire, Rutland, Northamptonshire, and Huntingdonshire, Bedfordshire, and Cambridgeshire.

Lincolnshire is the second largest of the English counties, though only half the size of Yorkshire. The part called the Uplands is laid out for pasture ; while the Fenland, now mostly drained and given up to tillage, is a fine corn-land. Because ancient Lincolnshire, with its vast expanse of fens and marshes, could provide abundance of fish and wild fowl it became a land of monastic foundations, the county of noble abbeys. It contains about 700 parishes.

Rutland, the smallest of English counties, has a population only equal to that of a little markettown. To its south is Northamptonshire, a long slip of land which borders on nine other counties - no other touches so many as this. 
Huntingdonshire is another very small county ; it belongs to the low level of the Fens and once contained Whittlesea Mere, the largest sheet of water outside the Lake District; but this has been drained and is now added to our Anglian cornfields and pasture lands.

Bedfordshire belongs to the basin of the " slow-winding Ouse," and though it contains much pastureland, it probably has, in proportion to its size, more ploughed land than any other English county.

Cambridgeshire also belongs to the basin of the Great Ouse, which divides it into two districts; the south, occupied by grassy chalk downs of the Gog Magog Hills ; and the north, that part of the Fenland which retains its old name, the Isle of Ely.

Hereabouts we have the flat marshy region known as the Bedford Level, comprising the greater part of the Fens-the whole Isle of Ely, about 90 square miles of Hunts, nearly Ioo of Norfolk, 47 of Suffolk, I2 $\frac{1}{2}$ of Northants, and the south-east portion of Lincolnshire, making 703 square miles in all. Two cuts of canals, the Bedford Rivers, Old and New, have been constructed from the borders of Huntingdonshire through the Isle of Ely, to confluence with river Stoke ; the New River is roo feet wide, the Old 70 feet, and both are navigable for upwards of twenty miles. A large area of land has been reclaimed for cultivation, and though the expenditure has been vast, the results have been worth it. The work was undertaken early in the seventeenth century by the Earl of Bedford aided by the celebrated Dutch engineer, Sir Cornelius Vermuyden, in the face of great opposition ; the usual outcry against "foreigners" being raised. 
The whole of this low-lying area, known as the Fens, at one time extended to 2,000 square miles, which tradition says was first overflown by the sea during an earthquake in the year 368 . It long after remained an inland sea in winter, and a noxious swamp in summer, and has been drained gradually by the successive efforts of the Romans, the Saxons, and the monks of the Middle Ages. Drainage works on a larger scale were undertaken in the reign of Henry VII. by Morton, bishop of Ely, and later a drainage act was passed by the advice of Lord Burghley in I6or. Since the making of the Bedford Level, similar works have been undertaken in 1807 , when Rennie made the Great Level, and again in I844 when the Middle Level was made. Notwithstanding which, great inundations occurered in 1862 and in 1877 .

The three Eastern counties include Norfolk and Suffolk (the two generally known as East Anglia), and Essex in the basin of the Thames. Though Norfolk is the fourth largest county in England, it is scarcely as large as the North Riding of Yorkshire. The eastern part is so flat that its rivers spread out into wide lakes and marshes, called "Broads," which are the home of many wild fowl. Like Suffolk, it is a good wheat-growing country. The latter county is also famous for its sheep and cattle, and a short strong horse known as the Suffolk Punch. Norfolk was once our greatest manufacturing county, and its commercial integrity in olden times gave us the word " sterling" - a sterling pound was a reliable weight of bullion according to the standard of the Easterling merchants trading there. If the ancient parish churches of Norfolk and Suffolk are found to be excessively large for the villages they now serve, it must be remembered that before the Black Death these villages were thriving towns. 
"England has greater counties" than Essex, sings A. S. Cripps; but

Their place to hers is small.

Low hills, rich fields, calm rivers,

In Essex seek them all.

Omitting Essex, the counties which may be grouped in the Thames basin are, on the northern bank, Middlesex, Hertford, Buckinghamshire, and classic Oxfordshire; on the southern side, Kent, Surrey and Berkshire.

The county of Middlesex is the smallest but one of the English counties; it is more populous than Yorkshire, though Yorkshire is twenty times larger.

Hertfordshire is a pleasant county which sends its waters down long gentle slopes to the lower lands of Middlesex and Essex; the Lea flowing through the centre, from west to east, and then forming the boundary between this county and Essex.

Buckinghamshire contains the Chiltern Hundreds, at one time covered with forests of beech and oak, but now either cultivated or laid out in pasture; also the rich Vale of Aylesbury, which sends large supplies of milk and butter to the London markets.

Oxfordshire and Berkshire are divided by the winding waters of the Thames. In the latter is situated the Vale of the White Horse, where King Alfred fought the battle of Ashdown, broke the power of the Danes, and kept England a Christian land-the memory of all which is preserved in the immense figure of a horse carved on a green hillside, its bold outline remaining visible century after century, so long as the chalk is kept "scoured" of the grass, by the proud men of the Vale. 
Surrey, divided into two parts by the North Downs, is a pleasant land of hill and dale, noble parkland, and wide spreading heath, all within easy reach of the Londoner.

Kent has a boundary line of sea and river on three sides; on the west, the fourth side, it is entered by the North Downs, which become broader and broader, till they terminate in two sea-ends, known respectively as the North Foreland and the South Foreland. The county has three well-marked districts ; the high upland of the Downs; the centre which grows hops, corn, and cherries; and the low marshy districts which are characteristic of both its north and its south coasts.

Kent as " a sea-salted, wind-vexed promontory" sticking itself out into the sea, has been curiously compared with the county of Fife in the sister kingdom of the north-both were made the landing-places of early missionary monks of whose enterprise we have reminders in the ancient cities of Canterbury and St. Andrews; and more curious still both have for a coat of arms a white horse over the legend, "Invicta "- the watchword of an unconquerable spirit common to the two.

The four southern counties comprise Sussex, Hants, Wilts, and Dorset.

Sussex is divided into three well-marked belts, the Weald, the South Downs, and the narrow strip of coast. The Weald was once covered with dense masses of forest, though it is now mostly under tillage. The South Downs are a range of broad, round-backed hills, grass-grown to the top, and famous for their mutton producing qualities. The sheltered coast-line is well dotted with sea-side resorts. 
Hampshire is a large, fertile and well-wooded county between the Thames Valley and the English Channel. In the north the Hampshire Downs run eastward where they divide into the North Downs of Surrey, and the South Downs of Sussex. By the British it was called Gwent, " the country of downs."

The four counties of South-east England, the corner from Kent to Hants, is a pleasant land of the old Saxon Weald, the rolling Downs, and the chartered marshes of ancient Romney:

" I'm in love with all these three,

The world and the Marsh and the Down Countrie;

Nor I don't know which I love the most

The Weald or the Marsh or the White Chalk Coast."

Wiltshire is entirely an inland county, "of billowy surface," consisting of upland tracts and table-land that send waters away to the Thames, to the Severn, and the English Channel. The largest of its pastoral chalk downs is Salisbury Plain, a bleak stretch of greensward occupying nearly 300 square miles. The highest of its chalk hills is Inkpen-Beacon, which rises where the three counties of Wiltshire, Hampshire, and Berkshire meet, and from which point four ranges strike out-the Chilterns running into the East Anglian Heights, the North Downs towards Surrey and Kent, the South Downs towards Sussex, and in opposite direction the Downs of Dorset.

Dorsetshire is another chalky county of small population. Between the North Downs and the South Downs of Dorset lies the Trough of Poole, a barren waste that yields nothing but blue clay, large quantities of which are sent to the Staffordshire Potteries. 
The three south-western counties are Somerset, Devon, and Cornwall - the last-named, however, repudiates the name county and styles itself a duchy.

Somerset is a county of very varied aspect, its hills and dales, its dark woods and clear streams, presenting landscapes of ever-changing charm and diversity. On the west a branch of the Exmoor runs out of Devonshire; in the middle are the Quantock Hills; and on the east are the Mendips, whose rocks yield to the miner lead, copper, and zinc.

Lovely Devonshire, or " leafy Devon," is the land of glowing colour, with its red earth and masses of green foliage; its azure sky and purplish seas ; its cliffs of pink and grey marble, lighted up by ferns, and flowers, and softened by graceful creepers; where villages nestle amidst orchards, and pretty cottages are gay with bushy myrtles and climbing fuchsias; where busy vales alternate with great silent moors, and never a scene presents itself that fails to charm the eye of the beholder. In the north is Exmoor, in the south Dartmoor, and between these two gloriously natural wilds. lies a broad, beautiful, and well-cultivated plain,

Cornwall, sometimes called West Wales, stretches out like a horn of land with stern and rocky coasts, into a wild and stormy sea. The river Tamar, which divides it from Devon, makes almost an island of it ; and in other ways it is as a county apart.

The counties have even been classified by the statistical seismologist, from which it would appear that the most " unshakable counties " are Northumberland and Durham, which are practically immune from earthquake. The county most subject to seismic disturbance is said to be 
Hereford, for in the cathedral city alone over 200 chimneys were fractured in the earthquake of I896.

Wales in area is about one-twelfth of Great Britain, and one-seventh the size of England. Its twelve counties may be divided into two equal groups, six in North Wales, and six constituting South Wales.

Anglesey, the island county, joined to the mainland by bridges, is the only one in Wales which can be described as low and flat. Carnarvonshire, opposite to it, is the most elevated, not only in Wales, but in South Britain, containing Snowdonia, which is literally the Hill of Snow. In shape it is a long headland of the hardest and oldest rocks, which seems to hold half the western sea in its crook.

Denbighshire, containing the romantic Vale of Llangollen, is the delightful Wild Wales of George Borrow. Flintshire, though small in area, is rich in minerals; its deposits of coal, iron, lead, and zinc have attracted a dense and busy population. Montgomeryshire is the most thinly populated county in Wales, notwithstanding that it possesses mines of lead and copper, and quarries of stone and slate.

When the Lordships Marcher passed away under the reforming hand of Henry VIII., and the ancient feudal territories were made into new Welsh counties like Denbighshire and Montgomeryshire, or were tacked on to already existing Welsh or English shires, they became subject to English law. As the lords clung to many of their feudal privileges, difficulties afterwards arose in dealing with Welsh " manors." One place, Dinas Mawddwy, had ani nteresting history. Its former immunities from English law made it the 
resort of thieves and adventurers, and the doings of the red-haired robbers of the Mawddwy make a lurid chapter in Welsh history. Henry VIII. tacked on this Alsatia to the county of Merioneth, but the wild natives did not appreciate the customs of " shire ground," and expressed their feelings by hanging a judge, Baron Owen, when he rode on circuit there.

Merioneth is very beautiful, but very rainy. It is one of the most sparsely populated counties in England and Wales, and contains a larger area of mountain land than any other. This fact impressed the I7th century author of "Le Fidèle Conducteur pour le Voyage d'Angleterre," who writes that "Merioneth is composed entirely of mountains. These are so high and so close together that the shepherds guarding their flocks on the heights, who can talk with ease among themselves from one mountain top to another, must spend a day's journey if they wish to meet and embrace those with whom they converse in this way.'

Cardiganshire sweeps with a crescent of mountains along the open bay to which it gives its name, and into which the rugged capes of Pembrokeshire stand out further. Here is Milford Haven, the grandest natural harbour in Great Britain, with sea-room to protect the whole British navy, and so land-locked as to shelter it from every wind that blows. The population of Pembroke is not entirely Welsh-there is a district called Little England-beyond-Wales, in which a colony of Flemings was settled by Henry I.

Radnorshire, on the eastern slopes of the Plinlimmon range, is mostly bleak upland and marsh, and the least populous part of South Britain. Brecknockshire, or Brecon, is also inland, and thinly populated. 
Glamorganshire, which can be described as a microcosm of Wales, is the most populous and most wealthy of all its counties and is second in point of size. The Vale of Taff is the busiest in the world, with its iron-works, coal-mining, smelting furnaces, and other allied industries. Carmarthenshire, the largest of the Welsh counties stands partly in this busy industrial region and shares in its wealth.

To memorise the names of all the English counties, when such an exercise was thought to be educational, the following Hexameter was constructed :-

, Nór cum-dur : wé la-york : che-de : nót-linc: shróp-staf-le-rút norf :

Hér-wor-war-nórtha: Bed húnt-camb-súff : mongl-óxfo-buck-hért-ess :

Sóm-wilt-bérk-Middleséx : corn-dév-dors-hámpSurrey-Ként Suss.

Such as are contiguous southward are unjoined, as in we la.

Such as are contiguous eastward are hyphened, as che-de.

This absurd metrical verse was used as an " aid to memory" in the public schools of the country a century ago ; it is given in Grey's " Memoria Technica" and Lowe's "Memories." 


\section{XXIII}

\section{SHIRE PROVINCIALISM.}

Although earlier in these pages it has been declared that the term "province" has no obvious meaning in this country, it cannot be said that we fail to recognise " provincialism," in the sense of that unsophistication which comes of living remote from the centres of art and culture.

The phrase, "He comes from the Shires," implies provincialism, when used by Londoners and residents of the home counties, and is generally applicable to the natives of the inland shires and those more remote from the capital. There is said to exist an old and deep-rooted antagonism between the Saxon and Jutish kingdoms of the south east, and the Anglian kingdoms of Mercia and the north, which exhibits itself in the use of this and similar phrases, expressive of contempt and pity for inferior manners and morals. In Norfolk and Suffolk, however, which were distinctly of Anglian origin, the half-educated people, ignorant of geography, describe other parts which they believe less blessed and less advanced than their own, as " down in the sheers." The East Anglian always adopts the tone of contempt when he speaks of a " sheere's man." The people of Norfolk, Suffolk and Essex almost invariably allude to their portion of England as " the three counties," and all the rest as " the shires."

At one time the shires were considered by East Anglians the extremest limit of civilisation.

"Oh 
no, my son he ain't a-gooin' tew India-he's agooin' father than that; he's a'gooin' inter the She-ars."

The true Sussex man, again, divides the land into two great divisions-Kent and Sussex are one, all the rest of the country are " the shires." Such is the attitude of mind assumed by the spirit of local patriotism in various parts of the kingdom.

The "home counties" are those containing and surrounding London, as Middlesex, Essex, Kent, Surrey, and sometimes Hertfordshire and Sussex, and thus in the legal world the " home circuit" of the judges of assize, is that having the capital for its centre.

During the Civil War a combination was formed, called the Associated Counties, the object of which was to keep the war out of these districts and to raise a force for the Parliamentarian faction. These counties were Essex, Cambridge, Norfolk, Suffolk, and Hertford (I642), and subsequently Huntingdon and Lincoln.

In former days any man who had not the good fortune to be born in the counties close around Iondon was dubbed a Shire-man, and when betrayed by his mode of speech, was regarded as nextdoor to a foreigner.

A " man from the shires," especially from those north of London was one who was regarded as a " provincial," as a slow, stupid fellow. Provincialism implies the inferior standard of culture that comes of a remoteness from the capital; as on the other hand the derivation of such words as "civility" and "urbanity" implies the superior influences of town life.

At the present day, however, there is a tendency towards absorbing the vitality of the provinces, and turning it into a superficial smart- 
ness, into the sterility of mere Cockney assurance. At the best, this could only eventuate in a glut of ability at the centre, andadreary waste of plodding mediocrity in the provinces.

In the phrase " shire horse" we have fairly good evidence that at a comparatively early period the word " shire" connoted the countryside, as it was that royal judge of horseflesh, Henry VIII., who ordered the breeding of " strong horses in the English shires"; and to that end imported Turkish and Spanish stallions to improve the native stock.

In each county often existed a separate and distinct group of thought; and life was largely conditioned by the distance of one county from another, in a time when travelling was difficult and intercommunication rare.

To the most casual observer a difference is always noticeable between the manners of the natives of the north and those of the southern counties' folk. Whether it arises from a closer association with continental peoples, or whatever the cause, there is always a more polished and pleasanter manner with the southerners than with north-country people. The northerner is noticed to be brusque, abrupt, and even outwardly rude in his manners, though on closer acquaintance it may be found that the rudeness is more apparent than real, that beneath the surface many sterling good qualities are to be found.

The harshness of the northerner is more than compensated for in the grit of the Lancastrian, whose natural shrewdness, of a more disinterested nature than that of the Yorkshireman, has produced the proverb-" "What Lancashire thinks to-day, England thinks to-morrow." 
It has been sought to divide England into two parts by drawing a line westward, from the mouth of the Trent; to claim distinctive characteristics for those north and south of this line of demarcation. Thus a Canadian authority on Emigration has said that 95 per cent. of the failures among English settlers in Western Canada came from the counties south of such a line. On the other hand an eminent Oxford authority on literature has declared that no one born north of the Trent could hope to become a master poet. These vague generalities are scarcely worth consideration. But it must be recognised that between the northern and the southern counties there was the wide belt of ancient Mercia, and the Mercian temperament while free of all Celtic influences was given a double Teutonic strength by the infusion of so much Danish blood. This is the true ethnological dividing line.

The subject of provincial dialects is too wide to be dealt with here, but of most countrymen " men from the shires "-it may truly be said, "Thy speech betrayeth thee."

The Northumbrian burr, or " cinder in the throat " has been supposed to be the last trace of the mode in which the Saxons pronounced words beginning with $\mathrm{R}$-as when Ripon was pronounced Hripum. 


\section{XXIV}

\section{COUNTY ATTRIBUTES AND CHARACTERISTICS}

Some counties have acquired a reputation for what they produce, or are supposed to have produced; others from the typical characteristics by which its inhabitants are recognised in the popular mind. Some have a traditional reputation for one thing, some for another, and thus a county-name becomes a distinguishing adjective.

To honour first human culture, we may start with the patriotic avouchment of the soldier-heropoet, Rupert Brooke-

\footnotetext{
For England's the one land I know,

Where men with Splendid Hearts may go :

And Cambridgeshire, of all England,

The Shire for Men who Understand.
}

To which rival counties might retort that such eminence is largely an imported virtue, a virtue to which all the other shires make willing contribution.

All north-countrymen are proverbially" longheaded and cannie," but Yorkshire men stand out, even among them for cuteness The traditional Yorkshire motto is said to be-

See all, hear all, say nowt;

Eat all, drink all, pay nowt;

And if tha does owt for nowt,

Do it for thisen.

In slang " a Yorkshire warehouse" stands for a shop or business-place where the customer is likely to be cheated or overreached. To "put 
Yorkshire on a man," is to overreach him in a deal. "Born in Scotland and bred in Yorkshire would cheat the devil," says another proverb.

A Yorkshireman's coat of arms, according to an old saying, consists of "A flea, a fly, and a magpie "-a flea, because it will bite anybody, and so will a Yorkshireman; a fly, because it will drink with anyone, and so will a Yorkshireman; and a magpie because it will chatter with anyone, and so will a Yorkshireman. Another version substitutes a flitch of bacon for the magpie" because it is no good till it is hung."

The burlesque blazonry of this heraldic jest is described in Notes and Queries (Seventh Series, I888); beneath this amusing description is printed :-

A Yorkshire Man's Coat of Arms.

A magpy behold, and a Fly and a Flea, And a Yorkshireman's qualifications you'll see ;

To Backbite and Spunge, and to Chatter amain,

Or anything else, Sir, by which he can gain.

The Horse shews they Buy few, though many they steal,

Unhanged, their worth nought, does the gammon reveal,

But let Censure stand by, and not bias the Mind

For Others as bad as the Yorkshire you'll find.

In explanation of the rhyme it may be added that in the arms are included " a ham pendant," and a "Demi-horse" for a crest; the motto beneath the whole being " Qui capit ille habet."

Nor is the sister county considered to be far behind in the attribute of business cunning. "Lancashire law, no stakes, no draw," is a saying to avoid the payment of a debt when only verbally made.

County nicknames in the shape of epithets have been applied to the natives of various counties from a variety of reasons, more or less cogentgenerally less ; as, being characteristically de- 
scriptive, oftener in a contemptuous sense than otherwise; or, in derision of some cliaracteristic product of the place.

Here are specimens-

" Buckinghamshire bull-dog."

"Cambridgeshire Camel."

" Cheshire Cat."

"Cheshire chief-of-men."

"Devonshire prowe" (?) proud.

“' Dorsetshire gobbler."

"Essex calf."

"Gloucestershire-a Cotswold lion" (i.e., a sheep)

" Hampshire hog."

"Herefordshire broadhorn."

" Hertfordshire hedgehog."

"Huntingdon sturgeon."

" Kentish long-tail."

“Leicestershire bean-belly."

“ Lincolnshire bag-pipe."

"Middlesex haydigger" (or clown)

" Norfolk dumpling."

" Northampton snob" (or cobbler)

" Nottingham lamb" (i.e,, a rowdy)

" Rutland white hare."

" Somersetshire Chewton bunny."

" Suffolk-Silly Suffolk."

"Wiltshire moonraker."

"Yorkshire tyke" (tyke may mean a sharp dog, or contrariwise, a clownish sustic. The word "tyke" is derived from the Celtic tiac " a ploughman ")

Sometimes these "pious opinions" of county attributes are put into rhyme-

Cheshire for men,

Berkshire for dogs,

Bedfordshire for naked flesh,

And Lincolnshire for bogs.

Derbyshire for lead,

Devonshire for tin,

Wiltshire for hunting plains,

And Middlesex for sin.

Another county rhyme runs in this wise-

Nottingham full of hogs ;

Derbyshire full of dogs;

Leicestershire full of beans ;

Staffordshire full of queans ! 
Staffordshire people spell the last word " queens," of course. Here is another rhyme of county comparisons-

Hampshire hogs ; Berkshire dogs;

Yorkshire bite; London white.

Yet another is

Bedfordshire bull-dogs,
Hertfordshire hedgehogs,
Buckinghams great fools!

The origin of the phrase, " Grinning like a Cheshire cat" has never been satisfactorily explained. It is a fact that Cheshire cheeses were once moulded in the shape of a cat, bristles being inserted to represent the whiskers. But what was a Cheshire cat? In the coat-armour of Hugh Lupus, the mighty earl of Chester, there occurred a wolf's head, which might possibly have been mistaken for that of a grey cat. But a " cat's face" was more probably seen in the arms of the city of Chester which empales the lions of England. The old armorists always drew this emblem like a leopard, and as it was affronte or full-faced, it might easily have been mistaken for a grinning cat.

Lincolnshire men, and sometimes also the fenmen of the contiguous counties, were nicknamed " yellow bellies," or " frogs," from the amphibious kind of life they led. "The drone of the Lincolnshire bagpipes"-this instrument was indigenous to East Anglia long before Scotia knew it -which was Falstaff's simile for melancholy, is supposed to be a cryptic reference to the croaking of its frogs.

It is said to be a biological fact that Lincolnshire folk have a head which in size is noticeably below the average dimensions of English skulls; 
but this cannot satisfactorily be connected with habits of environment.

In explanation of the epithet " moon-raker," a local legend tells of a Wiltshire farmer's wife who took a rake to rake the reflection of the moon from the river, under the delusion that it was a cream cheese.

In Bishop Hall's Vigidemiarum (Oxford I753) occurs-

\footnotetext{
$\rightarrow$ to depart

He gives me leave, and thanks, too, in his heart.

Two words for monie, Darbyshirian wise:

(That's one too manie) is a naughtie guise,

Who looks for double biddings to a feast

May dine at home for an importune guest.
}

To be "Derbyshire wise" is not to need two biddings to a feast-in Bishops Hall's time the hospitality of the Derbyshire people would not allow them to take a first refusal.

\section{A local couplet says-}

Derbyshire born and Derbyshire bred.

Strong in the arm and weak in the head.

This the natives naturally regard as libellous, and say the correct version in the vernacular ends " wacken in th' yed:" - that is, wide-awake in the head.

"Hertfordshire kindness" is an ironical expression, signifying a kindness one does to himself, or a good turn rendered for a good turn received. Fuller in his "Worthies" explains the proverb as a mutual return for favours received-" It being observed that the people in this county at entertainments drink back to them who drink to to them." Swift in the second Dialogue of his "Polite Conversation" uses the phrase-

Neverout. My Lord, this moment I did myself the honour to drink to your lordship.

Lord Smart. Why then that's Hertfordshire kindness. 
A feeble kind of wit has sometimes tried to pun on Shire names.

"Stafford law" is a slang expression for beating with a staff. Or, put in another form, one who has " had trial in Stafford Court" is one who had received a sound cudgelling for his pains.

To " go to Bedfordshire" is baby-talk for go to bed.

He who has a troublesome cough is humorously dubbed " a native of Berkshire."

There is a saying current in Cambridgeshire that "The bailiff of Bedford is coming." It is applicable to the River Ouse, which runs through Bedford, because when it is swollen with rain and overflows its banks it generally causes an inundation, bringing down suddenly abundance of water. By this saying persons are warned to drive off their cattle, lest they should be impounded by the " bailiff of Bedford," or, in other words, drowned.

A number of counties affect pet-names, and some have acquired nick-names. "Of all eloquence a nickname is the most concise," says Hazlitt.

Hampshire, trading on the supposed derivation of its name from the Saxon " ham." boasts itself the " Home-shire of England," claiming to be the " Cradle of Saxon rule in England."

The Isle of Wight, though legally a part of this county, holds itself aloof from it, and exhibits an old prejudice against " overners" or " overers" from the mainland. Then the gibe against the island is that it never produced " a good horse, a wise man, or a pretty woman." That's as may be. But it is a fact that the female population is remarkably below that of the opposite sex, and in a proportion not known elsewhere. 
Berkshire is sometimes "Breezy Berks" and sometimes " the Royal county," because it contains Windsor Castle, the ancient residence of a long line of sovereigns. Than " in Berkshire beechen woods" where could royalty find more soul-reposing privacy?

Shakespeare's county is " woody Warwickshire," and is still beautiful with the noble remnants of the Forest of Arden.

"That shire which we the Heart of England well may call," according to Michæl Drayton, is Warwickshire.

Warwickshire is divided into the Arden and the Feldon by the river Avon. North of the river is the woodland remnant of the ancient Forest of Arden; south of it is the Feldon or open country, from which the trees were all felled when civilisation dawned.

"Warwick woods are sweet," sings John Drinkwater.

Buckinghamshire is rightly called "Beechy Bucks," containing as it does, among other charming woodland resorts of like character the famous Burnham Beeches-it is a county of many charms for picknickers, and within easy reach of the great metropolis.

Norfolk has been described as one big goosegreen interspersed with villages and hamlets.

"High Suffolk," or the woodlands, is the inland portion of that county famous for its excellent butter.

Whether it boasts of the distinction or not, Rutland is the smallest county; and it was not altogether inappropriate that there should have been published in I746 "Tom Thumb's Map of Rutlandshire." 
Nottingham is the county of "Merrie Sherwood," where beneath the greenwood tree the bold Robin Hood and the heroic Cour-de-Lion played their legendary pranks in the picturesque days of old; and where those bygone days of chivalry and romance are still recalled by the presence of the series of stately homes popularly known as " the dukeries."

Devonshire is justly allowed to be " the Shire of sea-kings," having emblazoned on the roll of fame the names of so many of her gallant sonsDrake, Grenville, Raleigh, Frobisher, Hawkins, Davis, the Gilberts, and not a few others of lesser note. These were the sea-dogs who made the spacious times of Queen Elizabeth so glorious, and laid the foundation of England's sea-power.

Middlesex, though originally a Kingdom, is the smallest but one of all the English counties ; though Yorkshire be more than twenty times larger, it is more populous than the northern " county of broad acres," because it contains the greater part of the vast metropolis. Middlesex is sometimes referred to as " rural London."

Macaulay declared "An acre in Middlesex is better than a principality in Utopia."

Cornwall is the " delectable duchy" and enjoys the proud distinction of being a duchy in itself, and a royal one to boot.

It is the English Riviera. The native poet declares-

I love thee, Cornwall, and will ever-

For why? thine equal knew I never!

Another Cornish poet sings of-

A sweet soft breeze by Cornish seas, the blue Atlantic gleaming The rugged cliffs, the fishing skiffs that lazily lie dreaming.

So much for its climate. Concerning its soil we have the saying- 


\section{Cornwall will bear a shower every day,} And two on Sunday.

The ancient kingdom of Cornwall, which is believed to have stretched inland far enough to include a portion of Somerset, had a long line of kings, most of them Christian and in deadly antagonism to the pagan West Saxons; among them were Cador, Blederic, Ivo, and Bletius.

Legend hath it that a tract, now submerged forty fathoms beneath the waves, once connected Land's End with the Scilly Isles. This was the " sweet land of Lyonesse," the mythical country from which came good King Arthur.

The last Earl of Cornwall was John of Eltham, youngest son of Edward II. In the following reign Cornwall became a duchy - the first in England-by act of parliament, Edward the Black Prince being invested Duke of Cornwall by the ceremony of conferring a wreath, a ring, and a silver rod. Since that time the title Duke of Cornwall has successively devolved to the heir apparent of the King of England.

Somerset, "the land of home and shrine," has been called " the most English of counties." Its story is the epitome of English history; its lake-dwellings at Glastonbury go back beyond the ancient Britons, and its legend of Joseph of Arimathea has its roots in the Christian era; it was there Saxon Alfred broke the Danes, and Monmouth's pathetic rabble were scattered; nowhere have fact and legend, down to the days of Pickwick and Beau Nash, mingled themselves so pleasantly to the English taste, than in the history of " rare Somersetshire."

Zummerzet vor zeen'ry vair,

Of water, wood and land ;

Zummerzet where volk do speak Zo volk can understand. 
The characteristics of the sister county, Dorset, are said to be " homeliness and humbleness," where boastfulness has given way to lovableness ; its pastoral charms and rural simplicity live in the hearts of the nation, or at least the reading portion of it, as the delightful Wessex country of the great novelist, Thomas Hardy. The Dorset dialect has a literature of its own.

Cheshire, the gateway of North Wales, obviously took its name from the county-town. There is a rhyme-

Chester of Castria took the name

As if that Castria was the same.

Between Cheshire and Lancashire there appears to exist an affinity which may, or may not, be the outcome of their adjacency. In modern times this is expressed in the similarity of many of their industrial pursuits, but in olden times it possibly had its roots in the identity of theit feudal obligations. This is shown in the old recruiting ballad of King Henry V., at the time of Agincourt, which begins with-

Go call up Cheshire and Lancashire.

In this the King was making no invidious comparisons between the martial spirit of the various counties; he was merely making the first call on his own personal royal appanages, for he was. Duke of Lancaster, and Earl of Chester and Derby.

Flintshire is the smallest of the Welsh counties, and Glamorganshire contains Cardiff, the Welsh metropolis.

Carnarvonshire is a county of watering-places and Monmouthshire a county of castles and abbeys, Cardiganshire has a hinterland behind the picturesque shores of Cardigan Bay that, not undeservedly, has been called the Garden of Wales. 
Pembrokeshire, or at least the southern portion, has been called Little England beyond Wales, owing to the settlement of a colony planted there by Henry I. in the I2th century-though it was not a colony of Englishmen but of Flemings!

Radnorshire was called by Thomas Fuller a " chequered county," on account of the striking contrast presented by the fruitfulness of the eastern and southern parts, and the roughness and unevenness of the mountains to the north and west.

A county sometimes lends its name to a commodity, or a quality, or even to an operation. "Staffordshire blue" is another name for Wedgwood blue, a characteristic hue of the famous ware produced in that county.

"Kentish fire" is rapturous applause, or "three times three and one more." The expression originated (says Brewer) with Lord Winchelsea, who proposed the health of the Earl of Roden, on the I5th August, 1834, and added, "Let it be given with the Kentish fire." In proposing another toast he asked permission to bring his Kentish Artillery into action again.

Chambers' Encyclopædia states that the phrase arose from the protracted cheers given in Kent to the No-Popery orators in I828-9.

Lore and Legend of the marvellous kind not infrequently enter somewhat largely into these county attributes.

The lore of Kent is extensive, and its legends are many; as might be expected from the importance of its position. It even boasts, like Ireland, a saint who charmed away its snakes, and ordained that even imported ones should die there. Thus the I5th century chronicler, William Caxton: "Thanatos, that is Tenet, is a ylonde 
besydes Kent and hath the name Thanatos, of deth of serpentes, for ther ben none. And the erth thereof sleeth serpentes yborn in other londes. There is a noble corn land and fruitful. It is supposed that this ylonde was haalowed and blessed by St. Austyn the first Doctour of Englishmen."

Kent, by its situation, was always the gateway of invasion which always came from the ancient east; through it also ran the highway of communication between this country and the outside world. Its legendary lore is therefore not without allusion to this great historic fact.

A "Kentish man" and a "man of Kent" are not quite the same thing. The former is applied to one resident in West Kent; but a man of Kent is one born east of the Medway. These men went out with green boughs to meet the Conqueror, and obtained in consequence a confirmation of their ancient privileges from the new king. They called themselves the "Invicti" (the unconquered).

This fanciful claim of the easterlings to set themselves up above their brethren of the west is, it is needless to say, quite baseless. East Kent from its position often formed the British vanguard, and bore the brunt of every invader's attack ; but the boast that the " men of Kent" were never conquered cannot be substantiated.

The earliest bishoprics were generally co-extensive with the kingdoms; the two sees of Canterbury and Rochester denote that for a time at least there were separate rules in east and west Kent. The terms East and West Kentings were preserved until the fall of the Saxon monarchy.

When the Conqueror marched from Dover towards London he was stopped at Swansconope by Stigand at the head of the Men of Kent, all 
with oak boughs on their brawny shoulders, presented as emblems of peace, on condition of his preserving inviolate the Saxon laws and customs of Kent ; or else they were ready to fight unto the death for them. William agreed to their terms. From this arose the traditional distinction between the Men of Kent and Kentish Men; the former being the Jutish " Invicti " of the eastern division, the latter the dwellers between Rochester and London, a more mixed population, owing to the incursions of many settlers. 'The Saxon Chronicle has allusions under date 853 and 865 to the "Men of Kent" fighting in Thanet (that is, in East Kent) against the Danish pagan invaders. Under date 902 and 999 mention is made of forces in West Kent under the name of Kentish men. These distinctions evidently existed before the Norman Conquest and the survival of Gavelkind Tenure and other Free Kentish customs lends some colour to the legend.

"The tailed men of Kent" was an epithet of derision once applied to the inhabitants of this county. At first it appears to have originated with, and been confined to, the Kentish family of Le Chat, one of whom cut off the tail of Becket's horse as the great churchman was riding through Stroud (Rochester). The saint's vicious assailant, says the legend, was excommunicated, and his posterity cursed with " long tails."

Judging by the various literary allusions to it, the legend had a wide-spread popularity. Thus Andrew Marvel in "The Loyal Scot"-

For Becket's sake, Kent always shall have tails. Again-

As Becket, that good saint, sublimely rode

Heedless of insult, through the town of Strode. 


\section{In Drayton's " Polyolbion " we read-}

Kent first in our account doth to itself apply,

Quoth he, this blazon first-I, ong tails and liberty.

The Golden Legend says that Augustine and his followers were pelted out of Strode in Kent with the " tayles of thorneback or lyke fysshes," in consequence of which the saint invoked judgment on the inhabitants. The discerning critic says this episode really took place at Cerne in Dorsetshire, and is " another story" altogether; anyway the men of Strode were said to be born, not with fishes' tails, but horses' tails.

In the reign of Queen Elizabeth Kent was so notorious for highway robbery, that the word Kent came to signify a " nest of thieves." As thus, Taylor the Water Poet (I630)--

\section{Some bookes are arrogant and impudent:}

So are the thieves in Christendome and Kent.

Coming down to the present day, Kent is claimed as " the real Dickens county." What says the great novelist himself of the county he loved so well ?

"Kent, Sir-everybody knows Kent-apples, cherries, hops and
women."

As an Englishman's feeding is not the least part of his life, it is by no means surprising that certain counties have acquired a reputation, sometimes of a doubtful kind, in the domain of food production and culinary achievement.

Where are to be found such high merit of toothsomeness as in Devonshire cream and Kentish cobs? of culinary perfection as in Yorkshire pudding and Norfolk dumplings ? of fine breeding as in White-faced Hereford cattle, Black Berkshire pigs, or in Lincolnshire sheep (except in the latter case of " improved Leicesters.") or of fine 
feeding as in a Hampshire hog or a Durham ox ?

Sometimes the pride of productiveness crystallises into rhyme-

The Downs are sheep, the Weald is corn,

You be glad you are Sussex born.

Of sheep, however, no one county possesses the monopoly of excellence. The "White Dorsets," with their twisted horns, and the " Old Norfolks," with faces black or mottled, have some claim to fame, while "Shropshires" and "Hampshires" are by no means out of the running.

A "Norfolk capon" is a red herring ; and the nickname certainly contains an implied compliment to the Yarmouth fishery. The "Norfolk dumpling " is also very humble fare, consisting of a ball of dough and yeast boiled about twenty minutes, and lighter than the "Sussex pudding" of plain boiled paste. "Cheshire cheese" has a well-deserved world fame won for it by the rich pastures of the Vale Royal of England; and if "Dorset butter" is not widely known outside the metropolis, it is because the Londoner in his millions would not be without his " best Dosset."

There is a dialect song of the "Four counties" which enumerates their characteristic products in this rollicking chorus-

\footnotetext{
Dorset gives us butter and cheese, Devonshire gives us cream,

Zummerzet's zyder zure to please And set your hearts a-dream;

Cornwall from her inmost soul, Brings tin for the use of man,

And the four of 'em breed the prettiest girlsSo damme, beat that if you can!
}

Everybody has heard of Cornish pasty, baked in the shape of a torpedo, and containing a remarkable number and diversity of ingredients- 
pork, rabbit, beef, kidney, potatoes, parsley, onions, bacon, and what not. Hence the saying "The devil will not come into Cornwall for fear of being put into a pie."

Of Essex it was written by John Norden in I594-

“ This shire is moste fatt, frutefull, and full of profitable thinges, exceeding (as farr as I can finde) anie other shire, for the generall comodities, and the plentie."

Says old Thomas Fuller, "In Kent are all things that are to be found elsewhere, but more and better." It is " the garden of England," or at least one of them ; and is generally allowed the boast, " No hops like Kentish hops."

Some counties have their names associated with some characteristic product. "Worcestershire weeds" are elm-trees, which grow as prolifically in that county as oaks in Sussex or aspens in Berkshire. And Essex, like Worcestershire, can show its elm trees, noble in size and graceful in contour, by the thousand.

About the close of the sixteenth century certain English products had begun to acquire quite a national reputation for the excellence of their quality. These were mostly foodstuffs, and among them were Suffolk milk, Cambridge butter, and Gloucestershire cheese. For ham there was no place like Hampshire, and for pasties none could compare with those of Cornwall. Nottinghamshire was famous for its ales, and Bedfordshire for its malt. Essex had a reputation for its calves, and Lancashire for its kine. Leicestershire produced the finest beans. There was no wheat so white as that of Middlesex, and no pears so juicy as those of Worcestershire. Cheshire was widely known for its salt, and I,incolnshire less so for its eels. Incidental to these re- 
putations a Bedfordshire man was dubbed a "Malt-horse," a Liecestershire man a "Beanbelly," and a Hampshire man a "Hog."

Dr. King, a culinary authority of the seventeenth century, descanting on "The Art of Cookery," sang-

Cornwall squab pie, and Devon white-pot brings;

And Leicester beans and bacon, food of kings.

Of the last-named dish it may not be out of place to quote an anecdote which shows the high estimation in which it is held by some palates, not necessarily Leicestershire, but certainly critical.

When the Lord Mayor, sheriffs, aldermen, etc., of the City were once seated round the table at a public and splendid dinner at Guildhall, John Wilkes called out, " Mr. Alderman Boydell, shall I help you to a plate of turtle or a slice of the haunch? I am in reach of both, Sir." " Neither the one nor t'other, I thank you, Sir," replied the alderman.; "I think I shall dine upon the beans and bacon which are at the end of the table." "Mr. Alderman Moreley," continued the chamberlain, " which would you choose, Sir, venison or turtle?" "Sir, I will not trouble you for either; for I believe I shall follow the example of my brother Boydell, and dine on beans and bacon," was the reply. On this second refusal the old chamberlain rose from his seat, and, with very much astonishment in his countenance, curled up the corner of his mouth, cast his eyes round the table, and, in a voice as loud and articulate as he was able, called " silence!" which being obtained he thus addressed the chief magistrate, who sat in the chair:- "My Lord Mayor,-the wicked have accused us of intemperance, and branded us with the imputation of gluttony. That they may 
be put to open shame, and their profane tongues be from this day and date utterly silenced, I bumbly move that your Lordship is the proper officer to record on our annals that two aldermen of the City prefer beans and bacon to either turtle soup or venison."

Kent brewed famous ales even before it grew hops. Giraldus Cambrensis eulogised Kentish ale so long ago as the time of Henry II. During the reign of Henry VI. this particular brew was the subject of a curious edict which forbade any man in the county to make more than roo quarters of malt into ale for his own use at one time. To this singular regulation has been attributed the fact that the vast quantities of ale found in the cellars of the gentry of the county at the time of Jack Cade's rebellion, which began in Kent, went far to foment and increase the boldness and ferocity of the rioters.

It is not often that a well-known fare has its demerits crystallised into a proverb, but Suffolk has achieved that distinction. The stony cheese upon which the farmers of this county fed their labourers in the eighteenth century was declared by the poet Bloomfield " too hard to bite." Hence arose the saying, "Hunger will break through stone walls or anything except Suffolk cheese." In " Suffolk White" (its famous breed of sheep) perhaps the present-day county may be allowed to have redeemed its character, and there was certainly no sturdier breed of English steeds than the old " Suffolk Punches."

More than one county claims to be the " Garden of England," to say nothing of the Isle of Wight's pretensions in this direction. The strongest 


\section{The Story of the Shire}

rivals for the distinction are Kent and Worcestershire, both hop-growing districts and both famous for their orchards.

The characteristics of a county may sometimes be inferred from the spirit of its Folk Songs. In I893 The Leadenhall Press (London) issued a useful pioneer work of its kind," English County Songs." 


\section{XXV}

\section{COUNTY PATRIOTISM AND COUNTY RIVALRIES}

Local independence in the shires has begot local pride, and throughout the centuries has encouraged that form of local patriotism which expresses itself in developing local institutions with all the strengthening characteristics of a native individuality.

Local patriotism crystalises quite as frequently around the county of one's nativity as it does around one's native city ; as witness the existence in London, and other great cities, of " County Associations," instituted for the regular assembling of inhabitants drawn from some particular shire, just for the simple pleasure of a social intercourse that recalls the familiar places and faces of a well-remembered childhood. And nothing in life, perbaps, is more pleasurably reminiscent than to live again, if only for a brief space, within sound of one's native dialect, with its characteristic twang and all its peculiarities of intonation!

Mr. Thomas Hardy, the eminent novelist, in addressing the Society of Dorset men in London, said :- " No more curious change has come over London social life of late years than the rise of that almost total disregard of provincialism among its constituents and casual sharers which nowadays pervades the city.

" In former times an unfamiliar accent was immediately noted as quaint and odd-even a 
feature of ridicule in novels, memoirs, and conversations of the date. So that, while it was the aim of every provincial, from the squire to the rustic, to get rid of his local articulation at the earliest moment, he now seems rather to pride himself on retaining it-being, in fact, virtually encouraged to do so."

Dorset is the scene of Hardy's immortal "Wessex" stories, and as the readers of his great play "The Dynasts" are aware, Dorset has played its part in the drama of reality, for Dorset people were very nearly concerned in the Napoleonic wars, as they had been at an earlier era with the Spanish Armada. Indeed, in every epoch Dorset men have been in the forefront of the nation's most honourable achievements. To its natives the county is " Dorset dear."

In London a number of the English County Societies have recently amalgamated for increased social and patriotic facilities. Those already affiliated include The Royal Society of St. George, East Anglians, Cornish, Cumberland and Westmoreland, Channel Islanders, Devonians, Gloucestershire, Hampshire, Men of Kent, and Kentish Men, Shropshire, Staffordshire, Surrey, Somerset Men, Men of Sussex, Vectensians (Isle of Wight), Warwickshire Folk, Wiltshiremen, and Worcestershire.

There is the Society of Dorset Men in London and a few others outside the affiliation. Then there is the Surtees Society, with its headquarters at Northallerton, a learned literary body which concerns itself with everything relating to the history and social life of those parts of England and Scotland between the Humber and the Firth of Forth on the East, and the Mersey and 
Clyde on the West, " a region which constituted the ancient kingdom of Northumbria." This Society was founded in 1834 and has published many volumes.

"County Feasts," as they were formerly called, have been regularly established in Iondon from the earliest decades of the seventeenth century. Some counties-Devon and Cornwall, for instance, -are perhaps more clannish than others, but numbers of them have not failed to cultivate their local patriotism by instituting in the city of their adoption, wherever it may be, some kind of annual re-union for the renewing of old memories, for recalling the fondly remembered scenes of a by-gone youth in some distant shire.

\section{God gave all men all earth to love, But since our hearts are small \\ Ordained for each one spot should prove Beloved over all.}

Mr. Hilaire Belloc, who has made Sussex all his own, says-" Note you, many kingdoms and counties are prodigal of their names; because their names are of little account and in no way sacred, so that one will give its name to a cheese and another to a horse, and another to some kind of ironwork or other, and another to clotted cream, or to butter, and another to something ridiculous, as to a cat with no tail. But it is not so with Sussex, for our name is not a name to be used like a label and tied on to common things, seeing that we were the first place to be created when the world was made, and we shall certainly be the last to remain "-and then somewhat inconsistently with such proud and prejudiced patriotism he adds"there are only two things in Sussex which Sussex designs to give its name to, and the first is the spaniel, and the second is the sheep." 
But if among the common things be reckoned iron, then the best of that commonplace but useful metal was made in this county for quite a century or two before the coal-smelted iron of Staffordshire became famous. Sussex ironwork, especially in the shape of old bygones, such as fire-backs, is much sought after by connoisseurs. Our extravagant eulogist, Mr. Belloc, while ignoring the "iron-age" of that southern county, calls Sussex " the captain ground and head county of the whole world"-which surely is county patriotism in excelsis.

Sussex generally is proudly patriotic in a quieter way, as for centuries it shared with its more prominent neighbour the honours and the responsibilities long attaching to the Cinque Ports, two of which are in the county.

\section{Dover, Sandwich, and Winchelsea,}

Romney and Rye, the five ports be.

Nowhere does county patriotism burn more fiercely than in Nottinghamshire, the county of Robin Hood and Sherwood Forest. Here the territorial spirit has bred the famous Nottinghamshire Archers who fought together so long ago as II38, when under Peverel, Lord of Nottingham, and custodian of the castle, they fought at the Battle of the Standard and in the next century at Falkirk and Bannockburn. In the I4th century they were conspicuous for their bravery at Nevill's Cross, Cressy and Poictiers, but exactly five centuries ago, at Agincourt, they fought for the first time on record as Sherwood Foresters, their flag being described by Drayton, the Elizabethan poet :

Old Nottingham, an archer clad in green, Under a tree, with his drawn bow that stood, Which in a chequered flag far off was seen :

It was the picture of bold Robin- Hood. 
County patriotism may be commendable when it gives us a New Hampshire in the United States, or another Cornwall at the Antipodes, but when it seeks to exalt itself by the depreciation of a neighbouring county it assumes a form of county consciousness which makes little appeal.

Pride leads to self-comparisons, and not infrequently engenders rivalry. The local rivalries of various counties are amusing in the peculiar forms they assume.

If size alone gave the pre-eminence, Yorkshire, " the county of broad acres" would be an easy first.

County rivalries are wide-spread, as indeed are other local jealousies ; and they find many modes of expression. One in the Midlands is particularly invidious without suggesting any reason for making the comparison-" It shines like Worcestershire against Gloucestershire" is a saying decidedly esoteric on the face of it though it may have its explanation in the river that flows through both of them.

Substitute the names of almost any two adjacent counties for those of Cornwall and Devon in the following doggerel, and it will pass current as the expression of local rivalry in almost any part of England-

Cornwall was Cornwall when Devon was a pup,

Cornwall will be Cornwall when Devon's busted up.

The natives call Devon "the Queen of the English Counties."

There is a Cheshire proverb expressive of provincial pride-." Better wed over the mixon than over the moor" ; that is, an alliance with a family close at home (mixon is a local term for a dung heap) is more desirable than one over the moorlands of Staffordshire, through which the long road 
to London wound its way. It was a feeling upon which old gentry acted by contracting intermarriages to perpetuate ancient friendships.

By the contrasting epithets "Lancashire Witches" and "Cheshire Cats," the eighteenth century beaux of the former county were said to toast the ladies of these neighbouring shires.

Cheshire largely comprises the "Vale Royal of England," where cows are more in evidence that cats.

A man with little fight in him is said to be " as valiant as an Essex lion," an " Essex lion " being an innocent calf. To this depreciatory reference the local retort is-

Essex you say, is famed for calves :

We thank you really for your pains,

For this you prove in our behalves

We're famous most for head and brains.

As Essex is a flat marsh-drained region, it is easy to interpret "Essex stile" as the nickname for " ditch." Thus the local proverb-

Essex stiles,

Kentish miles,

Norfolk wiles,

Many a man beguiles,

Essex is flat, though Norfolk and Lincolnshire on the whole are flatter; but its Saltings, as those marshes along the Thames Estuary are called, give a healthier glow and a fiercer appetite than any inland moorland. It has been dubbed the Cinderella County" : yet its poets are eulogistic-

England has greater counties,

Their place to hers is small.

Low hills, rich fields, calm rivers!

In Essex seek them all-

Essex, where I that found them

Did but lose them all.

Essex men are popularly supposed to be " much married men." The theory is that they commonly 
take wives from outside their own county, and that the Essex marshes are particularly fatal to married women, the result being that Essex men frequently have a succession of wives-some five or six, and instances of double that number have been recorded.

Properly understood the phrase " Silly Suffolk" is not derogatory. The adjective does not connote foolishness, but holiness. The term applied originally was " selig," the Saxon word for sacred ; and the county was " Selig Suffolk" because in olden times it was renowned for the number and beauty of its churches. " Silly Suffolk," however, is the term which has captured the popular fancy, and as William Hazlitt says, " a nickname is the hardest stone the devil can throw at a man."

The self-sufficiency of the small self-contained and locally administered areas is seen in the diversity of local custom, but in none more so than in the absence of any common or national standard in a matter so important as that of weights and measures. At one time the weights and measures varied in some detail or other, in nearly every county in England; till, in the interests of trade, uniformity of standard had to be enforced by Act of Parliament some 30 or 40 years ago.

In different markets so common a commodity as butter was sold by the pound which was reckoned variously as containing $16,17,18$ or 20 ounces, according to the custom of the locality. In the era of the flail before the threshing machine was thought of, 24 sheaves of corn were called a thrave in the northern counties; in some parts half that number, or if of wheat, were so called. 
To formulate rules or systems of reckoning would be impossible though the method of computation by scores seems to have been one more generally favoured. In weight this was evidently done to assimilate the reckoning with the "longhundred-weight" of I20 pounds; in Cheshire, for instance, it was easy to reckon that cheese at sixpence a pound was sixty shillings a hundredweight, and $f 60$ a ton. In the sale of wheat alone some 25 local weights and measures are in use ; I2 different bushels, 3 different hundredweights, I3 different pounds, Io different stone, and 9 different tons. A quarter of oats may mean anything from $304 \mathrm{lbs}$. to $528 \mathrm{lbs}$.

Troy Weight, still in use for the more precious commodities, is really London Weight, its name being derived from Troy-novant, the ancient name of the capital. While this weight prevailed in the strictly commercial circles of London, that known as Avoirdupois was good enough for the rest of the country. Avers is an old French word for goods in general, and poise means weight; so that Avoirdupois was the weight in use for all goods and chattels of ordinary daily dealings.

In the old days a varying standard mattered but little, the transactions being almost entirely local. But it would not be wise nowadays to encourage this spirit of individuality, the best interests of a commercial country with a worldwide trade imperatively demanding a common and uniform standard of weights and measures. This is where the self-sufficiency of Shiredom fails. 


\section{XXVI}

\section{COUNTY BADGES}

The ancient counties, being merely geographical districts, had neither banners nor corporate seals. On the formation of County Councils a few years back, the new authorities were sorely exercised to discover satisfactory and appropriate armorial insignia. The county having had no corporate existence was not capable of bearing arms. A city or town which was a county in itself, or a duchy like Cornwall, of course possessed armorial bearings.

There were spurious arms in plenty. The topographers of the last few centuries had often adorned their works with the arms of the ancient earls ; and " heraldry shops" and other irresponsible persons published sheets of " county arms," which were generally those of some principal town, or referrable to the arms of the first or some distinguished earl ; but in every case they were unauthorised and quite wrong.

To many counties it was easy to attach certain fanciful designs which might be appropriately (if illegally) used as badges.

Such unauthorised designs had in many cases already found their way on to the buttons of county constabulary, and elsewhere that a distinguishing county badge had become necessary.

Most County Councils at their formation avoided the fees-which amount to upwards of $£ 76$ 
-demanded by the College of Heralds for a legal grant of arms, and with praiseworthy economy, supplied themselves with bogus armorial bearings. The approved method of arriving at the desired result seems to have been to appropriate, with some slight modification, the arms of the countytown.

Thus we find Cumberland using a travesty of the arms of Carlisle, Westmoreland an imitation of the Appleby arms, and Devonshire a perversion of those of Exeter. The same unscrupulous methods of appropriation were followed by Cambridgeshire, Derbyshire, Leicestershire, and many others. Berkshire just altered the seal of Reading, and Bedfordshire the seal of Bedford, while that of Dorset County Council was suggested by the seal of Melcome Regis. Lancashire worked up the arms of the town and duchy of Lancaster; Cheshire altered to its own taste the arms of the earldom of Chester. Hampshire seized upon the arms of Southampton, and just by way of variety reversed the colours.

By way of Heraldic novelty Wiltshire introduced Stonehenge into its coat armour, and Nottinghamshire went one better by blazoning a lace-making machine upon its shield. And so the game of inventing sham heraldry went merrily forward at the epoch when the modern County Councillor brought the new enlightenment into an expectant world. There were others who, with a spice of originality, sought for the local emblems of old tradition to work up into heraldic charges, which they no doubt thought could be adopted with some claim to armorial appropriateness.

To the mind which had first to grapple with the problem, it naturally occurred that Kent would 
find an appropriate emblem in the White Horse of Hengist - the same charge is found in the arms of Hanover. With equal confidence Lancashire adopted the Red Rose, and Yorkshire the White Rose, the rival emblems of the two great Plantagenet houses.

The White Horse of Kent naturally recalls the name of "White Surrey," the horse which, according to Shakespeare, Richard III. had saddled for the field of Bosworth. It has been suggested that the name of Crookback's charger had nothing to do with the county of Surrey, the misleading word being simply Chaucerian spelling of Syria (Surrie) that it was customary to speak of a "white Syria horse" just as it was to speak of a "Barbary roan "-an explanation which is ingenious, if not convincing. The badge of the old Earls of Surrey was a White Horse, and it is to-day one of the supporters to the shield of the Duke of Norfolk, Earl of Arundel and Surrey. The proper badge of the county of Surrey is a White Horse holding an acorn in its mouth; or, alternatively a Swallow.

The Red Rose of Lancashire is the Rose of Provence, assumed by the earls and dukes of Lancaster. The White Rose of York was the badge of the Dukes of York, derived from the alliance with the De Cliffords, and borne by the latter family in memory of Rosemundia (the Rose of the World ") Clifford, the mistress of Henry II.

Northumbria's floral emblem is sung thus by the local poet-

Northumbria's emblem, $O$ tender the hue, Of its chalice at eve and dawn dimmed with dew, Aloof on the mountain and crag-crested fell, Northumbria's emblem, the bonnie bluebell. 
The so-called arms of Cornwall (fifteen bezants) are simply the device of the ancient earls of Cornwall. This coat of a field sable with fifteen bezants in pale $5,4,3,2, \mathrm{I}$, or, was borne by Condurus the last earl of Cornwall of British blood in the time of William I. Mr. Rodway contends that there should be ten bezants in pale, and that really they are Poix (peas) from the arms of Richard, Earl of Cornwall and Poic-tou.

Dugdale's Baronage begins a list of the mythical earls of Cornwall with Gorlois, who held the earldom in the time of Uther-Pendragon, King of the Britons. The King quarelled with, and slew Gorlois, for the sake of his wife, Igerna, whom he afterwards married, and who thus became the mother of the famous King Arthur.

For many of these interesting items of heraldic lore we are indebted to Mr. Alfred Rodway, the well-known Birmingham herald; he also names, or suggests, the following list of appropriate emblems which might be used as county cognisances.

For Bedford, a Black Eagle, derived from the De Courci family; for Berks, a Wheat-sheaf and Sickle, from the Hungerford family ; for Devon, a Blue Dragon or Lion rampant, from the De Redvers family; for Rutland, a Horse-shoe, from the De Ferrars family; and for Westmoreland, a Dun Bull, which was the badge of the old earls.

In quite a number of instances the county cognisance has been borrowed from the armorial bearings of its titular earl, or of some landed noble who has been long and closely associated with its history. Legends and proverbs have even grown up associating the name, or the arms of some dominating family, with the county on whose soil they have so long been settled. 
Bucks finds an appropriate emblem in a White Swan, gorged and chained proper, the badge of the Mandevilles, derived from the Fitz-Sweyns (Swans) and afterwards used by the Staffords, dukes of Buckingham. Cheshire has its Garb or Wheat-sheaf, borrowed from the arms of Ranulph de Blondeville, Earl of Chester. Gloucestershire has the Keys of St. Peter, a Boar's head, and also the arms of the De Clares who were Earls of Gloucester- "Or, three chevrons gules." Leicestershire claims a Castle, and a Pimpernel Flower (of five leaves); the Castle being Lear's Castle, the Pimpernel belonging to Robert Fitz Pernel, Earl of Leicester.

Essex appropriately displays Three Seaxes (Saxon swords) and Middlesex also fittingly adopts a Seaxe ; Hunts rejoices in a Huntsman, a Buck, and a Dog, either a rebus, or allusive to Robin Hood, Earl of Huntingdon. Notts emblazons a Bugle-horn, stringed proper, also evidently commemorative of bold Robin Hood. Oxon shows an $\mathrm{Ox}$ fording a River, and Cambridge displays a Bridge over the Cam. Lincolnshire is represented by a Golden Fleur de Lys, the badge of the Virgin, patron of the diocese; Norfolk by the Crowns of St. Edmund, the old banner sometimes used by East Anglia ; Durham by the cross of St. Cuthbert, its patron ; and Cumberland by a Saltire, the cross of Cospatric. For Dorset there is an ancient Galley, and the same for Monmouthshire, although the latter sometimes adopts the Red Rose of Lancaster. Northants borrows the device of its county-town, a Castle between two lions rampant ; and lastly, Northumberland sometimes displays the Bear of Bernicia.

There was not any, but that more or less

Something had got, that something should express. 
sang Michael Drayton. Thus in his " Agincourt"

Stout Warwickshire, her ancient badge, the Bear;

Wor'ster, a Pear-tree laden with the fruit ;

A Golden Fleece, and Hereford doth wear ;

Stafford, a Hermit in his holely suit ;

Shropshire, a Falcon tow'ring in the air ;

And for the shire whose surface seems most brute,

Derby, an Eagle, sitting on a root,

A swathed Infant holding in her foot.

A legendary Earl of Warwick was called Arth' that is, " the Bear," because he was so strong of limb; when a mighty giant came against him he slew him by just pulling up a tree by the roots, stripping it of its branches, and using it as a club. This is one version of the origin of the Bear and Ragged Staff; more probably the derivation is from one Urso d' Abitot.

Shakespeare alludes to the ragged staff as the cognisance of his native county in " 2nd Part of Henry VI.," V. I.-

Now, by my father's badge, old Neville's crest

The rampant bear chained to the ragged staff.

The Worcestershire device, "A Pear-tree fructed "is said to have been borne by its bowmen at Agincourt. Drayton in his Polyolbion has the line-

"Quoth Worcestershire again, 'and I will squint the pear","

And Leland ("Collectanea") describing the properties of the shires of Fingland, commences thus-

The property of every shire,

I shall tell you and ye shall hear

Herefordshire, shield and spear

Worcestershire, wring the pear.

In the coronation year of George V. a controversy arose concerning the Worcestershire county arms. It was suggested by the Standing Joint Committee that a new county badge should 
bear the nondescript blazonry of the Malvern Hills in the back-ground, and a pear-tree and a river; and that the three black pears should be given up because they rightly belonged to the city of Worcester and not the county. The suggestion almost needless to say, was not received at all favourably. The Pear of Worcester seems to have been derived from the old Benedictine quarter of the city known as Pirie.

Herefordshire boasts two symbols, the Golden Fleece and the Shield and Spear ; the latter being the attributes of Deo Herr, an old Teutonic leader. It will be recalled that Here-ford signifies the " army ford," the crossing where shield and spear were brought into play.

Staffordshire uses the Stafford Knot, like two S's interlaced, the family badge of that noble house, clearly a misappropriation of a personal cognisance to corporate uses; just as Warwickshire adopted the Bear and Ragged Staff, once the insignia of the great earls of Warwick.

A second Staffordshire badge is a Hermit, commemorative of the legendary St. Bertelin, a disconsolate prince who retired from the world and took up his abode in "the wilderness of Bethney," now the site of Stafford ; of which town he is the patron saint.

Proud Salop boasts a Golden Falcon, a Leopard's Head, and a White Lion. The recent grant of arms to the County Council gives the Leopard's head; the others are Yorkist badges borrowed from the Earl of March (i.e, ,the Welsh marches).

As previously noted (Chapter VIII.) the Earls of Derby took their title from West Derby in Lancashire, the earldom being a secondary title to the Duchy of Lancaster; and the badge of the 
Eagle and Child, otherwise the Bird and Bantling, has no reference whatever to the County, but belongs to the Stanley family (Earls of Derby), who derived it from the Lathoms. A silly legend has been manufactured for this badge, but Mr. Alfred Rodway is distinctly of opinion that it came originally from the Kilchecks or Kilchicks, and was really a rebus on the name of that family.

The badge directly allusive to the derivation of the name Derby, as it is given in Chapter VIII., is " a deer emparked" ; manifestly a rebus.

According to popular tradition the Hampshire badge of a Rose and Crown was granted by Henry $\mathrm{V}$. to certain troops, raised in this county, for the gallantry they displayed at the Battle of Agincourt, in I4I5. More correctly, the badge should be Three Roses, two argent, one gules. The county uses the same as Southampton, the coat assigned by Tudor heralds to Bevis of Hampton -and "three lions passant were the arms of Bevis bold."

The battle of Agincourt, if we accept the dictum of Drayton, was prolific in devices which are not otherwise familiar.

A silver tower Dorset's red banner bears

The Cornish men two wrestlers had for theirs.

We read also that Sussex " bore a black lion rampant, sore that fled, with a field arrow darted through the head."

The men of Surrey appeared with " checky blue and gold, which for brave Warren their first earl they wore" ; while the Devonshire band were distinguished by " a beacon set on fire." The cognisance of Somerset was " a virgin bathing in a spring;" and the men of Gloucestershire appropriated their city's arms, "In gold, three 
bloody chevernels." The Londoners and Middlesex men "as one, were by the red cross and dagger known "; and the men of Essex marched under Queen Helena's image-for that she, the British wife of the Emperor Constantine, was the founder of Colchester. Cambridgeshire flaunted " a bay upon a mountain, watered with a shower" ;

Suffolk, a sun half risen from the brake,

Norfolk, a triton on a dolphin's back.

The Wiltshire warriors appeared under "a crowned pyramid :" :

Berkshire, a stag under an oak that stood,

Oxford, a white bull wading in the flood.

Above the men of Rutland waved " an ermine ram," and those of Leicestershire carried aloft " a bull and mastiff fighting for the game." The county of Bedford exhibited " an Eagle perched upon a Tower" ; Northamptonshire, " a Castle seated high, supported by two Lions"; and

Huntingdon, a youthful hunter with a chaplet crowned, In a py'd lyam leading forth his hound.

-by "lyam" may be understood a leash. This device is not so unfamiliar, nor is the one attributed to "Old Nottingham," namely " an archer clad in green, under a tree, with his drawn bow." Also for Hertfordshire we have the canting device of "two harts that in a river play" ; and the lore of another county is recalled by the emblazonry on the Kentish streamer, of " a wood, out of whose top an arm that held a sword," and " above only one word, Unconquered." (see p. 235). As Hertford in Saxon was Heort-ford or Harts'-ford, the arms of the town are " a hart couchant in water " and the county badge is sometimes a White Hart, and sometimes a "Red Hart fording a brook, and a Castle. 
For Lincolnshire a ship was " most neatly limned, in all her sails, with flags and pennons trimmed": Yorkshire had " a flaming lance," while the device of the sister county, Lancashire, was " through three crowns three arrows smeared with blood."

Cheshire had "a banner square and broad, whereon a man upon a lion rode" : Westmoreland's device was " a ship wracked, lying fired upon the sand": Durham's uplifted standard bore her proud ecclesiastical charge of "a mitre crowned with a diadem." For the two farthest counties, the fighting men of Cumberland unfurled their blazonry of " an armed man," and the Northumberland borderers theirs of "two lions fighting "-both devices deeply significant of the amenities of life in that disturbed region.

If there is a quarter to which one would naturally look for all those popular symbols traditionally associated with a county, it is surely to the regimental badges of a territorial army, employed thereon to identify each regiment with the locality of its origin. But the search would be very largely in vain, most of these military badges recording regimental achievements on the field of action, rather than territorial origin.

A study of the official chart of army badges published by Messrs. Gale and Polden, Aldershot, is exceedingly disappointing in this respect. An expert herald, like Mr. Alfred Rodway, can discover on it little or nothing of " local" interest. The commonest device introduced is the ancient Dragon of the Saxon and other Counts of the various districts in England, all, of course, derived from the Roman Dragon of Red Gold. 


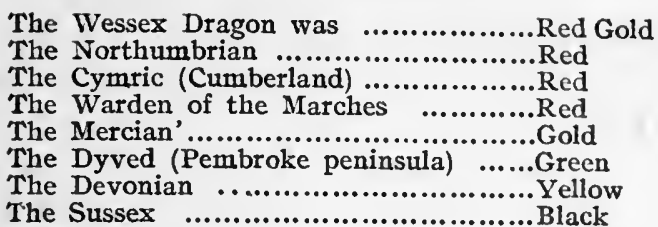

The Sussex Dragon is that of the old Counts of the Saxon Shore, and the Dragon of the Lords Warden of the Marches is that of the Roman duke of Britain (Dux Brittanarium). The Roman standard-bearer was called, from this standard, "draconarius." Mr. Rodway observes that although the Norman (de Redvers) who was made Earl of Devon is said to have borne a Yellow Dragon, it was probably the old Red Dragon of the Cymri brought from Scotland by the third Cymric wave when they conquered the Damnonian peninsula and Siluria.

Harold displayed a Dragon banner at Hastings, and as late as Henry III. it was a royal standard.

By the exercise of diligent care and keen insight, the long association of other emblems with local insignia might, perhaps, be traced. For instance, a connection between the Bear of Bernicia, with the Bear on Edward I.'s seal for Berwick-on-Tweed, might possibly be established. The old coins of the Bretwaldas bore the crude impression of a Bear. The prevalence of this symbol is really remarkable, being discernible in the shield of Penarth (the last syllable of which is arth, from the Greek Arcturus, " a bear") and the arms of the Ardens (Arthens). The same quadruped is heraldically persistent in dozens of other instances in which the place-name or the sur-name of the ruler will frequently be found to betray the traditional connection. 
Few of the Welsh counties have authentic badges, but the Three Golden Eagles of Carnarvonshre are significant of the imperial origin of Carnarvon in Segontium, the most westerly station of the Romans, and one visited by the Emperor Constantine. The ancient name of the town, Cær Custeint apparently indicates some connection with this Emperor. The Eagle tower of the castle is claimed as a Roman vestige.

Michael Drayton in hi,i stirring poem, " Agincourt," quotes the Eagles of Carnarvon, and also fits each of the other eleven Welsh counties with a battle standard. The poet gives to Pembroke a Boat being rowed by a Lady in a great Bay, no doubt allusive to the magnificent harbour there : to Cardigan, a Mermaid sitting on a Rock: to Denbighshire, a Neptune with his three-forked Mace : and to Carmarthen, a Rood whereon an Old Man leans and points at a star -doubtless intended for Merlin, " namer of the town." To Glamorgan he appropriates "a Castle high, from which a Flame shoots up into the sky" ; to Monmouth, Three Crowns imperial, supported with three armed arms : to Brecknock, a Warlike Tent upon whose top perches a Watchful Cock ; to Radnor, a Mountain of high ascent, thereon a Shepherd keeping his flock : to Flintshire, a Workmaid, in her summer weed, with Sheaf and Sickle : to Montgomeryshire, a Prancing Steed ; and, lastly introducing the most characteristic of all the Welsh animals, Merioneth is given Three Dancing Goats against the Rising Sun. These, if not according to all the canons of heraldry, show some fertility of imagination. 


\section{XXVII}

\section{THE COUNTY FAMILY}

That the " county family" is still a power in the land is apparent from one of the most recent pieces of legislation, whereby the control and welfare of the newly created Territorial Army has been committed, not to the democracy which constitutes the great bulk of it, but to the county magnates, whose high social position is presumed to carry more weight, than mere numbers could do, in any movement of national voluntary effort. It is a testimony to the dominating influence of county patronage that it has been deliberately preferred, as a foundation on which to establish a national army, to the broad-bottomed basis of popular patriotism. And in actual experience has not the administration of the great Territorial Army by the invaluable Territorial County Associations proved an unmitigated success, even under the stress of a great war? Also in the great public schools and universities there are invariably established officers' Training Corps, the assumption being that the youths at these institutions belong to the " ruling class," and are fitted by birth or status to hold positions of authority.

The official dignitaries of the county are the Lord Lieutenant, the High Sheriff, and the Justices of the Peace. The limits of their jurisdiction are always accurately known, for the county boundary is the most enduring of English divisions. 
For a long time it has been customary to select the ruling powers of a county from its resident nobility and gentry; as a rule the Lord Lieutenant from the former, and the High Sheriff from the latter.

Though "Shrievalty expenses" are (or have been) notoriously high, as a rule it is the ambition of the English country gentlemen to serve this honourable office one year of his life.

To be High Sheriff and " ride in a golden coach "; to look forward to having it recorded on monumental tablets in the parish church that Johannes Such-a-one, armiger, had been " high sheriff of this county in such and such a year"; this has been the most frequently cherished ideal of many a noveau riche attempting to found a family.

The claim to the distinction of being accounted a county family was in former days founded on documentary evidence substantiating the undisturbed possession of real estate over a number of generations. But the rule is much relaxed in these days of commercial competition, when the mere holding of real estate is rot so profitable as it was, and when an industrial plutocracy is generally ready to buy out the impoverished old landed families. To buy an estate, settle upon it, and for the holder (in the first or the second generation) to have filled the office of High Sheriff, is now almost sufficient to confer the status of a county family.

"County society" is typical for its class exclusiveness. Till recent times even the commission of the peace was supposed to be reserved by them for the squirearchy, and in the eighteenth century the " justice of mean degree" was not to 
be tolerated. Not only was nomination made, or suggested, by the judges of assize, for the office of High Sheriff, but also for suitable additions to the county magistracy. But this was when an enormous power was wielded in every branch of local government by nominated bodies-when in fact, there was a recognised ruling class, and the democracy was as yet inarticulate. As yet the elective principle had not been allowed to keep pace with the ever-growing requirements of modern local government.

When the fictionist has sought to create the ideal country gentleman, he has invariably depicted him as dutifully responsive to every demand the "county" makes upon him-to the calls upon his time, his purse, his resources. For instance, that delightful character, Sir Roger de Coverley, Steele and Addision's conception of the perfect country gentleman of the sixteenth century, is a justice of the quorum as a matter of course, and one who fills the chair at quartersessions with dignity and marked ability. We learn, too, that he has served his turn as sheriff and "rode in procession at the head of a whole county, with music before him, a feather in his hat, and his horse well-bitted." We could expect nothing less of the worthy knight, who is held up to us as the model of the fine old English gentleman.

Tennyson illustrates the old county stock in his "Sea Dreams," presenting the type in-

who

Sir Aylmer Aylmer, that almighty man, The county god-

Saw from his windows nothing save his own, 
and who belonged to

These old pheasant-lords,

These partridge-breeders of a thousand years,

Who have mildewed in their thousands doing nothing

Since Egbert.

The foolish Justice Shallow of Shakespeare is not intended to be a fair sample of the county magistracy which, for centuries, has upheld the dignity and reputation of Quarter Sessions-

Mastering the lawless science of our law,

That codeless myriad of precedent.

The highest type of a pure blooded territorial family is traditionally supposed to be the Norfolk Howards; and from that legendary reputation, a witty slang applied their name to the worst kind of blood-sucking body vermin. In which connection it is curious and amusing to note that, in I863, a person named Bugg actually changed his name by legal process to Norfolk-Howard. The duchy of Norfolk has been held by the Howards for a long period, and they are descended from several ancient princes who inherited the earldom and duchy.

All the same, the How ards are not of the ancient Norman nobility. Ancient lineage, the real old families, are oftener found among the gentry (and sometimes even among the peasantry) than in the peerage; and there are Saxon families in several counties who can trace their pedigrees beyond the Conquest. The ancient Norman nobility were practically exterminated by the thirty years' Wars of the Roses, and when Henry VII. called his first parliament there were only twenty-nine temporal peers to be found. Of these twentynine but five remain. 
It is interesting to note that one county, Lancaster, has left its name to a foreign title of nobility. The Counts of Lancastro are an illegitimate branch of the royal house of Portugal, deriving descent from George de Lancastro, natural son of King John II. The name was assumed in remembrance of the descent of the royal Portuguese family from John of Gaunt, duke of Lancaster, through his daughter Philippa, wife of King John I.

The " County family" tradition of Old England is to be traced in many of the social conventionalities of Virginia and other southern states, where the ideas of caste distinction belonging to Elizabethan and Stuart times prevail, in a modified form, to this day.

Leaving aside these antiquated prejudices, the worthier influences of English shire government are to be recognised wherever the Englishman has settled himself abroad in the newer parts of the world. Wherever the English language is spoken and the English flag is flying overhead, in the most distant parts of the world, we find the idea of the Shire prevails-the Commonwealth of Australia has its shire and borough areas, and the great western dominion of Canada just as naturally divides its provinces into counties, though strangely enough, while in the United States the Sheriff, most ancient of local functionaries, remains the most prominent of executive officers, in the Colony the authorities have invented, as an intermediary through which the provincial legislatures may deal with each county area, an official known as the County Warden. 
The great fact observable is, that the idea of the Shire is always present. And in the working of this idea we see the orderly mind of the Englishman, wherever he is placed, beginning with the small immediate practicalities of local government, and growing to the great; proceeding quite logically, with the confidence acquired, from the simple to the complex, from the concrete to the abstract ; basing his idea of statecraft on the enduring motives of religion, national defence, the mutuality of civic life, and the common weal. 


\section{INDEX}

America, allusions to PAGE

Angel-cyn

$36,105,267$

Angles ............. 31

Arrays, milita $24-5,30,50,74$

... I69-I 73

Assizes 103, I10, 124, I53,

“Associated Counties, , I96-7

\section{Barmote}

Bedford level

Belgæ ...... 38-..... 40, 42-4

Bernicia 24, 26, 28, 57, 255, $26 \mathrm{I}$

Berwick ….. 62, I87, 26I

Bishop's Court ............ 205

Boadicea

45

Borders, see Marches

Borsholder

Borough-towns ......... I $45-6$

Bretwalda $\quad . . . . . .2029,26$ I

Brutus $\quad \ldots . . . .444,76,86$

Burghal Centres ...... 78, I 5

\section{Caractacus}

Central Criminal ........ $37-85$

Chamberlain's Court ... 205

Chancellor's Court ... 204-5

Church, its influences $64,98,107-8$, III I, I 28-9

Cinque Ports ........ 203-4

Comotes ............. 69

Communal interests ... r ro

Constables ... 109-10, I58

Coroner $\ldots \ldots . . . . . . . . . . . . . \quad$ I97

Count (title) ...... 94-5, 97

County Borough ...... 201

County Keeper ......... 124

Court of Passage ...... 204

Cymbeline
Danegeld PAOR

Danlelagh, Danela..... 79, 132

Danes, Danish influence 79

$$
\begin{aligned}
& \text { 26, } 30,33,55-6, \\
& 58,60,65,92, \\
& 102,213,232
\end{aligned}
$$

Deman, Doomsman ... 108

Durham 26, 57, 79, 93, 255

Ealdorman, Elderman

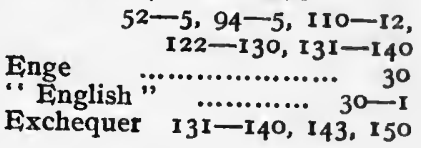

Family bond, or tie of Kinship $84,89,95,100-1,106$

Farm (or Feorme) ........ 132

Fens $\quad . . . . \ldots \ldots \ldots \ldots \ldots . \ldots . \ldots 212$

Folk Moot I06, I1 2, II9, I 42

"Forty-shilling Freeholder "

Fyrd (Ancient Militia)

$144^{-5}$

100, $127-30,173-4$

Headborough .......... rog Hereditary office $68,95,123$ Home Counties ... 162, 221 Hundred, Hundred Courts

$$
\begin{aligned}
& \text { 71, 99-101, ro6, } \\
& 108-9,113-14, \\
& 126,129,138,141 \text {, } \\
& 157,205
\end{aligned}
$$

Hustings ............. I12, 204

Hwiccas............. 28, 54, 77 


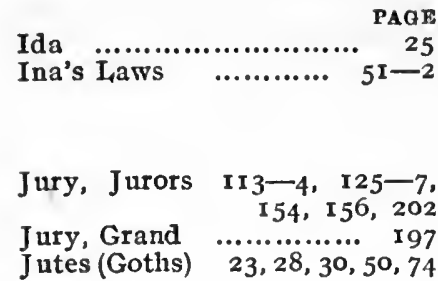

Knights of the Shire

II3, I 4 I, I 49

Lathe

Lindsey

London

Lord Lieutenant

130, I 68-1 76, 195, 263

Lord Mayor ........ II

Lothian $58,59,6 \mathrm{I}, 63-4$

Magistrates I10, 125, 157, 169, I 7I, 175, I 89, I $95-6,198,263$

Marches and Borderlands

$25,27,58-63,70-2$, 93, 98, 1 24, 189, $217-8,262$

Military Service $34,128-30$, I 70, I 74, 260, 263

Militia ............. I74-5 Motes (or Moots) I06, 109, 112

National Assembly

I06, III-I2, I 3I, I 42 Normans, Norman influence $30,32-3,60,87,129$ Norwegians ............... 65

Offa $\quad . . . . . . . .29,29,209$ Old Sarum
PAQE

Pale (Irish) $\ldots \ldots \ldots \ldots \ldots . .73$

Parliament $66-7$, III-I3,

Parish (or Priests' I4I, I43

Parish (or Priests' Shire)

Pendragon 99, II6, I28, 210

Phonicians $\quad \cdots . . . . .49,254$

Phondans 4I, 76

Picts $\quad \ldots . . . .664,86,88$

Posse Comitatus ...... I 29-30

Pseudo Shires

$54,87,182,206,208$

Quarter Sessions

I04, I 95, 205, 266

Rape 102

Recorder ..................... I96, 205

Ridings I03, 149, 163, I 75, I 83

Royal Navy $\ldots . . . . . . .204$

Saxonia

55

Saxons ........ 24, 29, 30, 33, 74

Saxon Shore ................ 49

Scots $\ldots . . . \ldots \ldots \ldots \ldots \ldots . . .6 \quad 64$

Shire Court

I06, I I 2-I4, I 26, I 42, I 95

Shire Reeve (or Sheriff)

$63,65,72,92,94$, I02, $107-8$, I10, 122-I 59, I 69, 195 ,

Sheriff-geld 263

.............. 132

Soke .................. IO2-4

Standing Joint Committee

Stannary Court 202, 256

Strathclyde ..... $27,59,208$

Tallies (Exchequer receipts) I34 Tithing (Decennary)

Trithing 99-I0I, I08-9, II6

Troglodytes $. . . . . . . . .103,120$

Troy-novant $\ldots . . \ldots \ldots \ldots . . . .4,250$ 


\section{INDEX}

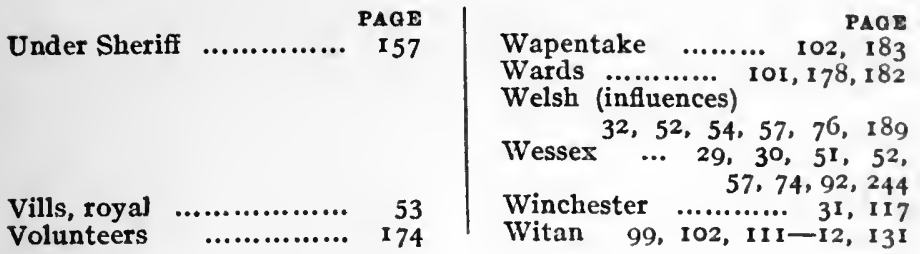

Printed in England for Heath Cranton Limited by Allison and Bowen Limited, Staford 



JS

3260

H3
Hackwood, Frederick William The story of the shire

\section{PLEASE DO NOT REMOVE \\ CARDS OR SLIPS FROM THIS POCKET}

UNIVERSITY OF TORONTO LIBRARY 
